\title{
Evolution of the breeding range of the Black-headed Yellow Wagtail (Motacilla flava feldegg)
}

\author{
Flavio Ferlini
}

Riassunto - Evoluzione dell'areale riproduttivo della Cutrettola capinera (Motacilla flava feldegg).

La Cutrettola capinera (Motacilla flava feldegg) nel periodo 18302015 ha manifestato una chiara tendenza ad ampliare il proprio areale riproduttivo con un'accentuazione del fenomeno a partire dalla seconda metà del XX secolo. L'espansione verso nord è stata favorita dai mutamenti climatici ed è stata caratterizzata da alterne fasi di avanzamento mediante dispersione per salti e successive diffusioni entro i limiti così raggiunti. Nei Balcani e nell'Europa occidentale la dispersione per salti si è manifestata soprattutto alla fine del XIX secolo e nella parte centrale del XX secolo permettendo alla sottospecie di raggiungere il $48^{\circ}$ parallelo nord. Nella porzione orientale dell'areale invece la dispersione per salti si è manifestata con maggior evidenza negli ultimi decenni del XX secolo e nel primo scorcio del XXI secolo. Sia in Europa (soprattutto orientale) sia in Asia il margine settentrionale è con buona approssimazione definito dall'isoterma $20^{\circ} \mathrm{C}$ di luglio. In Europa si è constatato anche uno spostamento verso occidente dell'areale e l'utilizzo di una nuova rotta migratoria, in progressiva intensificazione, che porta la sottospecie dall'Africa all'Europa attraverso lo stretto di Gibilterra. Contestualmente si rileva con sempre maggior frequenza la comparsa della Cutrettola capinera anche nei Paesi dell'Europa settentrionale. In Medio Oriente l'espansione verso sud-ovest in Siria, Israele, Libano e Giordania ha caratteristiche diffusive e sfrutta quasi esclusivamente ambienti naturali. La nidificazione in aree molto meridionali nella penisola arabica, determinata dall'attività antropica e in particolare dalla presenza di campi irrigati per la produzione di foraggio, dimostra la potenziale capacità della sottospecie di espandersi anche verso sud. In questo caso il fattore limitante è certamente la carenza di ambienti idonei vista la forte prevalenza del clima iperarido. Nell'Asia centrale, specialmente nel bacino idrografico del lago d'Aral, la diffusione della feldegg è stata favorita dall'irrigazione dei terreni ad uso agricolo. Nell'estremo margine orientale dell'areale non si apprezzano particolari movimenti né espansivi né recessivi.

Parole chiave: fattori biotici e abiotici, cambiamento climatico, espansione verso nord, Europa, Asia.

\begin{abstract}
The Black-headed Yellow Wagtail (Motacilla flava feldegg) has shown a clear tendency to expand its breeding range in the period 1830-2015, with an accentuation of the phenomenon during the second half of the twentieth century. Expansion northwards has been favoured by climate change and is characterized by alternating
\end{abstract}

Via Cantore 3, 27040 Castelletto di Branduzzo (PV), Italia

E-mail: flavio.ferlini@unipv.it

(C) 2016 Flavio Ferlini

Received: 29 March 2016

Accepted for publication: 24 July 2016 phases of jump dispersal and subsequent diffusion within the limits thus achieved. In the Balkans and in western Europe, jump dispersal occurred mainly in the late nineteenth century and mid-twentieth century, allowing the subspecies to reach the 48th parallel north. In the eastern portion of its breeding range, however, jump dispersal mainly took place in the last decades of the twentieth century and in the early part of the twenty-first century. In Europe (especially in the oriental sector) and in Asia, the northern edge of the range is defined with good approximation by the $20^{\circ} \mathrm{C}$ isothermal of July. In Europe, there has been a shift in its distribution range to the west and the establishment of a new, progressively more import migration route leading the subspecies from Africa to Europe across the Strait of Gibraltar. Concurrently, more and more sightings of the Black-headed Yellow Wagtail have been reported in northern European countries. In the Middle East, expansion to the southwest in Syria, Israel, Lebanon and Jordan has diffusive characteristics and exploits almost exclusively natural environments. In contrast, nesting in the southernmost parts of the Arabian Peninsula is determined by human activity, in particular by the irrigation of fields for the production of fodder, demonstrating the potential of the subspecies to expand further south. In this case, the limiting factor is certainly the lack of a suitable environment, due to the strong prevalence of a hyperarid climate. In central Asia, especially in the catchment area of the Aral Sea, the spread of feldegg has been favoured by the irrigation of the land for agricultural purposes. In the far eastern edge of its distribution range, no particular expansive or recessive movements have been observed.

Key words: biotic and abiotic factors, climate change, northward expansion, Europe, Asia.

\section{INTRODUCTION}

The Yellow Wagtail (Motacilla flava) is a polytypic species (Alström et al., 2003; Tyler, 2004; Alström \& Mild, 2005; BirdLife International, 2015a) which, pending more-detailed morphological and molecular analyses that could change the current classification, includes ten subspecies (Gill \& Donsker, 2015). The inclusion of so many races in a single species has resulted in less attention being given to each subspecies' breeding range, which have been described by various authors in very general terms and with reference only to macro-regions. Even when ranges have been reported on a map, detail has been scant: this is the case, for example, with Dementiev \& Gladkov (1954) and Ödeen (2001) who have described the whole range of the species, and with Cova (1969) on the European extension of the range; the maps of Alström et al. (2003) on the full range and of Porter \& Aspinall (2010) on that of the Middle East are more detailed. This has somewhat hampered our ability to re- 
cognize the changes that have occurred in the range of individual subspecies over time. An awareness of these changes is important because the birds are excellent ecological indicators; indeed, understanding these changes would allow us to analyse the biotic and abiotic factors at play in their breeding ranges and, thus, in the ecosystems that host them. Because evidence of this type has already been obtained for the Ashy-headed Yellow Wagtail (Motacilla flava cinereocapilla) (Ferlini, 2015), the aim of this study was to analyse the variations in the breeding range of the Black-headed Yellow Wagtail (Motacilla flava feldegg) (Figs. 1 and 2) that have taken place between 1830 and 2015, in order to understand the factors determining them. 1830 was chosen as the starting point because it was the year in which a 23 -year-old medical student, Karl Michahelles, described the taxon, reporting the appearance of a specimen captured in Split (Dalmatia), which he designated as Motacilla Feldegg (Michahelles, 1830).

\section{MATERIALS AND METHODS}

The present study is based on data obtained from the available literature. However, given the impossibility of consulting all the reports published during the long period under study, the data presented here should not be considered exhaustive; nevertheless, it is sufficient to obtain an understanding of the changes that have occurred as well as the current trends.

In reconstructing the dynamics of the variations in the breeding range of the Black-headed Yellow Wagtail, a confounding element was represented by the manifold scientific names used over the years to designate the variants of this bird. The following is an alphabetical list of the names encountered and considered for the purpose of transposing the data onto maps: Budytes aralensis, $\mathrm{Bu}$ dytes atricapilla, Budytes feldeggi, Budytes flava suschkini, Budytes flavus feldegg, Budytes flavus kaleniczenkii, Budytes flavus melanocephalus, Budytes flavus paradoxus, Budytes flavus xanthophrys, Budytes melanocephala, Budytes melanocephalus, Budytes melanocephalus paradoxus, Budytes melanocephalus xanthophrys, Budytes melanocervix, Budytes melanogrisea, Budytes melanogriseus, Budytes nigricapilla, Budytes nigricapillus, Budytes paradoxus, Budytes raddei, Budytes xanthophrys, Motacilla atricapilla, Motacilla feldegg, Motacilla feldeggi, Motacilla feldeggii, Motacilla feldegg aralensis, Motacilla feldegg feldegg, Motacilla feldegg melanocervix, Motacilla feldegg melanogrisea, Motacilla feldegg melanogriseus, Motacilla flava feldegg, Motacilla flava feldeggi, Motacilla flava kaleniczenkii, Motacilla flava melanocephala, Motacilla flava raddei, Motacilla kaleniczenki, Motacilla kaleniczenkii, Motacilla melanocephala, Motacilla melanocephala paradoxa, Motacilla melanocephala xanthophrys, Motacilla melanogrisea, Motacilla nigricapilla, Motacilla paradoxa, Motacilla raddei and Motacilla xanthophrys.

Another problem that has led to inaccuracies in the data collected on Europe, especially in the past, consists in a confusion between males of $M$. f. feldegg and particularly dark-headed individuals of $M$. $f$. thunbergi. This condi- tion occurs for the latter on account of plumage abrasion especially in the late breeding period, but it can occur also in early spring (Alström et al., 2003). In addition to their vocalizations, a good element of distinction is the colouration on the rear-crown and hind-neck, which in thunbergi is at least slightly blue-grey rather than completely black and less sharply demarcated from the mantle than in feldegg (van Duivendijk, 2010). This potential for confusion was emphasized by Van den Berg \& Oreel (1985), promoting revisions of previous sightings of feldegg by numerous rarities committees of central and northern Europe. In actual fact, the problem was not new since it had already been pointed out by Dresser et al. (1871-1881) when stating about feldegg that:

"The present species is essentially a southern bird ... and although very dark varieties of Motacilla viridis [here understood as thunbergi] somewhat closely resemble it, yet these may always, so far as my experience goes, be distinguished by the top of the head being slaty black and not pure black, a broad streak on each side of the head only being black, and the underparts are not so bright yellow».

An additional factor of uncertainty and possible inaccuracy is represented the alteration of place names that can occur over time, especially in Asia as mentioned in 19th-century texts. Finally, the linguistic diversity of the bibliographical sources must be mentioned (the documents are written in 34 languages, including Latin), with some (such as those in 19th-century Russian) difficult to interpret.

\section{RESULTS}

The findings of this study have been separated into five different time periods. Moreover, for the sake of simplicity the whole breeding range has been divided into three geographical areas: Europe, the Middle East (Turkey, Georgia, Armenia, Azerbaijan, Cyprus, Syria, Lebanon, Israel, Palestine, Jordan, Iraq, Iran, Saudi Arabia, Bahrain, United Arab Emirates, Kuwait, Oman, Qatar and Yemen) and central Asia (Asian Russia, Kazakhstan, Uzbekistan, Kyrgyzstan, Turkmenistan, Tajikistan, Afghanistan, Pakistan and western China).

\section{From 1830 to 1865 \\ Europe}

The Black-headed Yellow Wagtail was reported as a breeding species in Greece (Malherbe, 1843; Landerer, 1857; Lindermayer, 1860; Homeyer, 1881), in particular in a letter dated 1840 in which Brehm mentions the presence of the bird in Attica (Niethammer, 1966); a nest with eggs was reported in Acarnania on 29 April, 1859 (Dresser et al., 1871-1881). Lanfossi (1840) also mentions European Turkey as a breeding area, with nests found near Istanbul in summer 1863 (Dresser et al., 1871-1881).

To the north of the Black Sea, the subspecies was found nesting near the estuaries of the Dniester and Tylihul (Demidov, 1840); it was also noted in eastern Crimea (Kaleniczenko, 1839). 


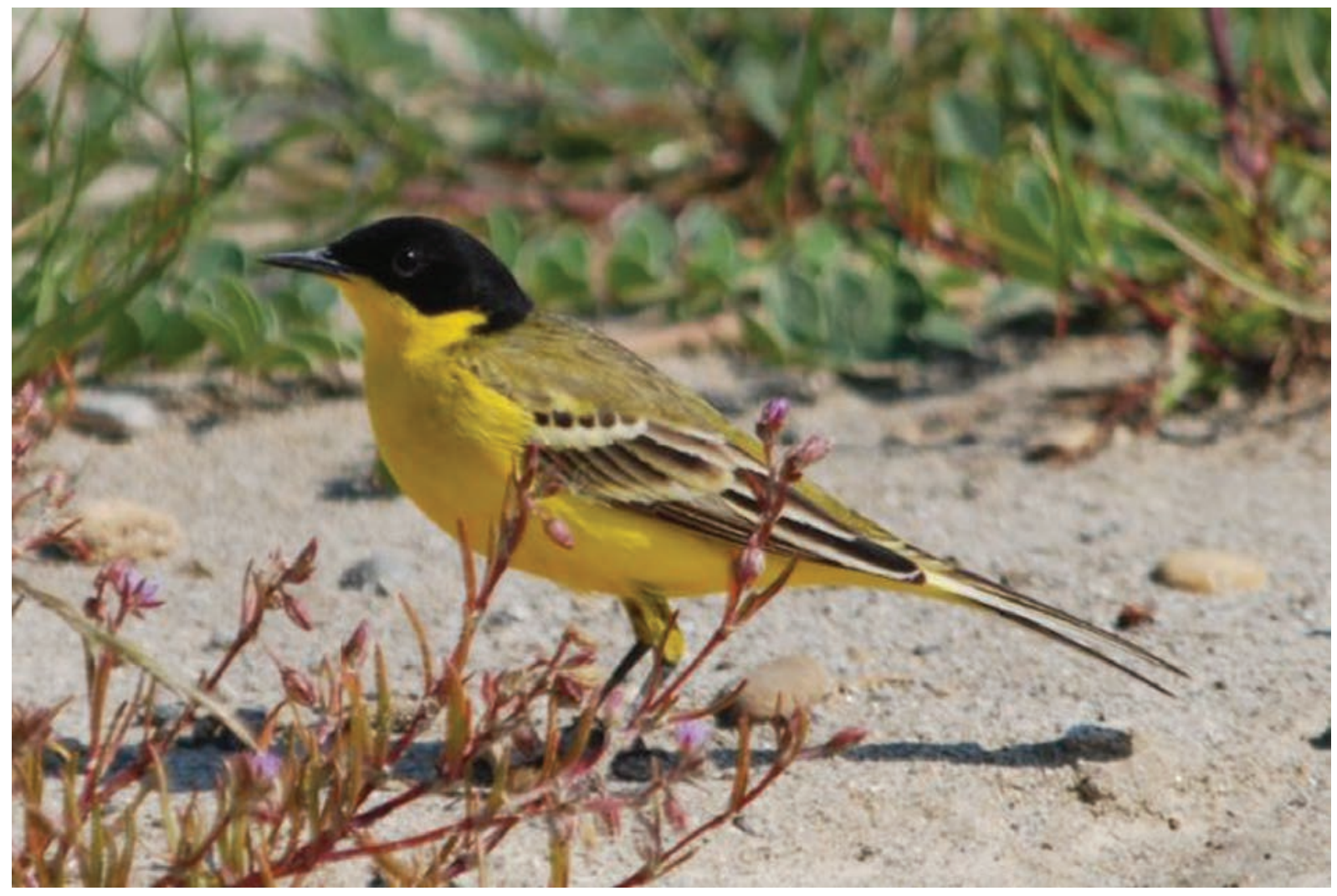

Fig. 1 - The Black-headed Yellow Wagtail (Motacilla flava feldegg), male (photograph: Egidio Fulco).

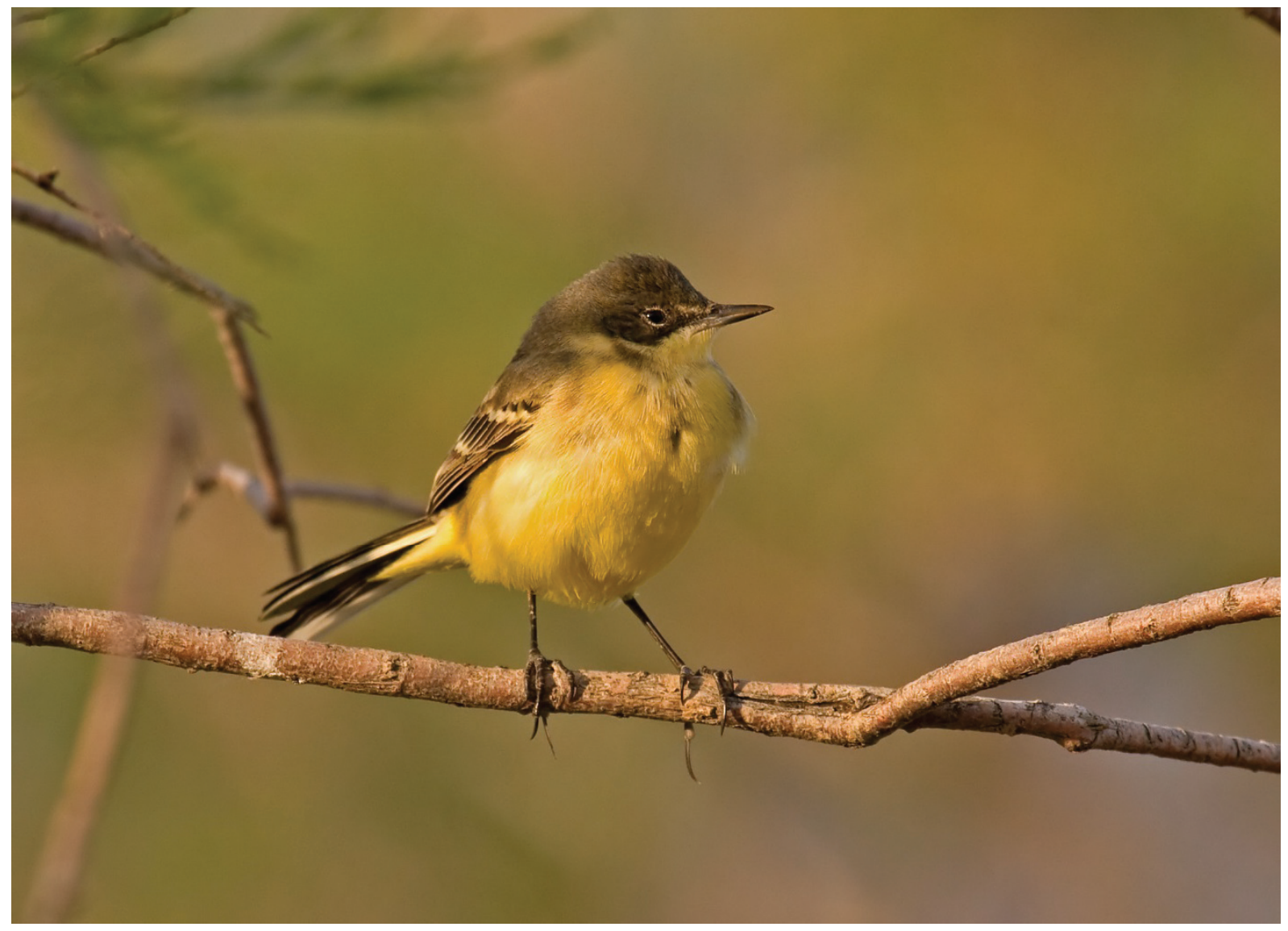

Fig. 2 - The Black-headed Yellow Wagtail (Motacilla flava feldegg), female (by Andreas Trepte; via Wikimedia Commons). 
In addition, some works cite Sicily and Dalmatia as included in the breeding range of the Black-headed Yellow Wagtail, but most authors considered it a rare migratory bird to the island (Bonaparte, 1832-1834; Genè, 1835; Benoit, 1840) and a regular migrant to the Dalmatian coast (Temminck, 1835; Degland, 1840). In the Veneto region of Italy, one individual was reported in San Martino Buon Albergo in May 1840 and three in Verona in 1860 (Arrigoni degli Oddi, 1899).

Schinz (1837) reported the capture of a specimen in the Canton of Neuchatel (Switzerland). The bird was also reported in southern France (De Serres, 1845; Belis \& Olioso, 2011; Jaubert \& Barthélemy-Lapommeraye, 1859).

\section{Middle East}

The Black-headed Yellow Wagtail was reported nesting in Turkey near Istanbul, at Smyrna (Gonzenbach, 1859 ) and in the eastern province of Erzurum (Dickson \& Ross, 1839; Curzon, 1854).

In his journey from Poti (Georgia), on the coast of the Black Sea, to Tehran (Iran) via Tbilisi (Georgia) and Yerevan (Armenia), de Filippi (1865) encountered the taxon in wet and grassy sites, but only starting from Armenia. The subspecies seemed, therefore, to be absent along the east coast of the Black Sea and in the Georgian interior, whereas in actual fact (as based on subsequent data) it was probably present along the route in Iranian territory. Indeed, the bird was reported along the southern edge of the Caspian Sea at Sari (Mazandaran) in 1829-1830 (Menetries, 1832) and breeding in Aspas and Shiraz (Fars Province, southern Iran) (Blanford, 1867). Blanford (1867), citing specimens of melanogrisea caught in Persia, indicated Baluchestan as their possible area of origin.

The subspecies was also found on Cyprus, where it was observed in summer 1787. There, the bird was drawn for the first time by the botanical illustrator Ferdinand Bauer (Fig. 3) for a volume written by John Sibthorp, which, however, never went to press (Sclater, 1904).

In Palestine, the Black-headed Yellow Wagtail was noted only rarely during migrations through the territory (Tristram, 1864; 1866).

\section{Central Asia}

In central Asia, the Black-headed Yellow Wagtail was considered a breeding species especially in the northern part (Degland, 1849; Balfour, 1858). The subspecies was reported around the Aral Sea (Kazakhstan and Uzbekistan) (Lanfossi, 1840) and in the Bukhara Region of Uzbekistan (Degland, 1840). However, the subspecies had already been reported in this area prior to 1830 by Lichtenstein (Eversmann \& Lichtenstein, 1823), who described a specimen attributable to melanogrisea. Schlegel (1844) reported sightings also in the area generically called Bucharia (which includes Kazakhstan, Kyrgyzstan, Tajikistan, Turkmenistan and Uzbekistan), without giving more specific geographical references.

The breeding range of feldegg as known for the period 1830 to 1865 is shown in Fig. 4.

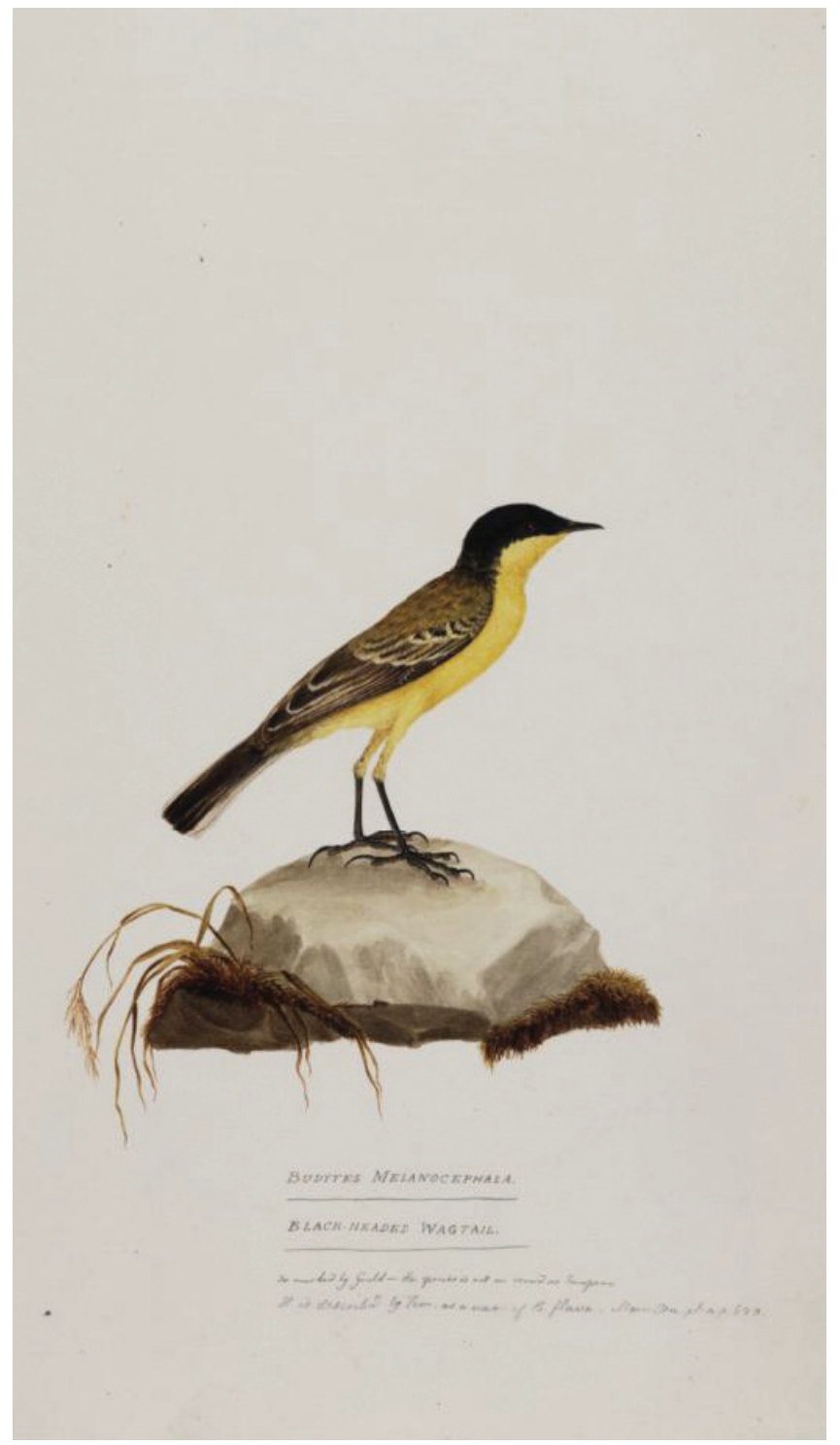

Fig. 3 - Budytes melanocephala. Ferdinand Bauer's drawing for "Fauna Graeca Sibthorpiana" or "Drawings of the Animals of Greece and the Levant", Vol. III (source: Bodleian Library, University of Oxford, UK).

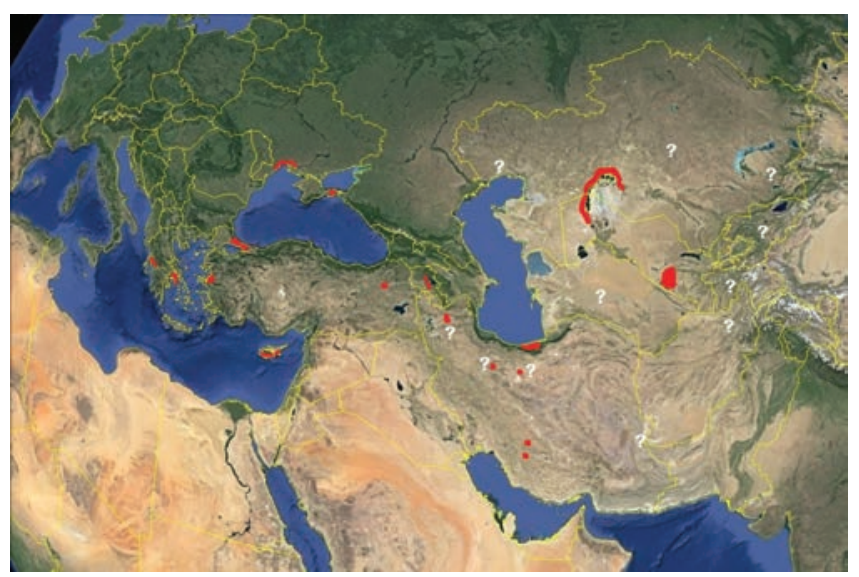

Fig. 4 - In red, the 1830-1865 breeding range of Motacilla flava feldegg. The white question marks indicate doubtful sites. 


\section{From 1866 to 1900 \\ Europe}

The Black-headed Yellow Wagtail was commonly encountered in Greece, especially along the coasts and islands of Attica, the Peloponnese, Acarnania, Thessaly and Evia. It was also present in the Cyclades (Mykonos, Naxos and Santorini) (Krüper \& Hartlaub, 1875; Almäsy, 1898; Ottó, 1899; Reiser, 1905) and it is possible that some pairs were breeding on Corfu (Reiser, 1905).

In European Turkey, nests with eggs were reported near Istanbul (Dresser et al., 1871-1881).

In June 1900, a few pairs were reported nesting in Gornja Plavnica (Montenegro) along the northern shore of Lake Skadar (Führer, 1901) (Fig. 5).

As in previous decades, many authors included Dalmatia in the breeding range of the Black-headed Yellow Wagtail. However, only one young specimen (preserved at the British Museum, London) was described as coming from this geographical area (Sharpe, 1885), while Kolombatovic reported generally on breeding birds without providing detailed geographic information (Csörgey, 1903). More detailed data have been provided for spring (from March to early May) and late summer (early September)
(Tschusi \& Dalla-Torre, 1887; 1888; Lorenz L., 1887; 1892) periods. Indeed, all the specimens collected from 1890 to 1899 and preserved at the Museum of Zagreb were captured in the spring (6 March to 9 May, with a prevalence of specimens captured in April) (Rössler, 1903). Moreover, Madarász (1899) reported that he did not encounter the Black-headed Yellow Wagtail along the Dalmatian coast in 1898, so it is highly probable that the subspecies was only a migratory species in this area.

Reiser (1888) did not include the Black-headed Yellow Wagtail among the birds established for Bosnia and Herzegovina up to 1888; later, in 1892 and in 1896, the subspecies was reported migrating in this area (Reiser, 1892; Almasy, 1898; Besserer, 1899). In Serbia, probable nesting pairs were observed in Kovin (Vojvodina) between 1896 and 1900 (Almasy, 1898; István et al., 1899; Madarász, 1899-1903). The Museum of Natural History of Sarajevo houses preserved specimens collected in Serbia (Prokuplje, Niš, Ristovac and Negotin) in May and June 1899 and 1900 , as well as a male intermediate flava x feldegg ("dombrowskii") specimen caught in Negotin on 11 May, 1899 (Vasić \& Obratil, 1990). As early as 1892, the bird was considered to be a nesting species of eastern Serbia (Reiser, 1892).

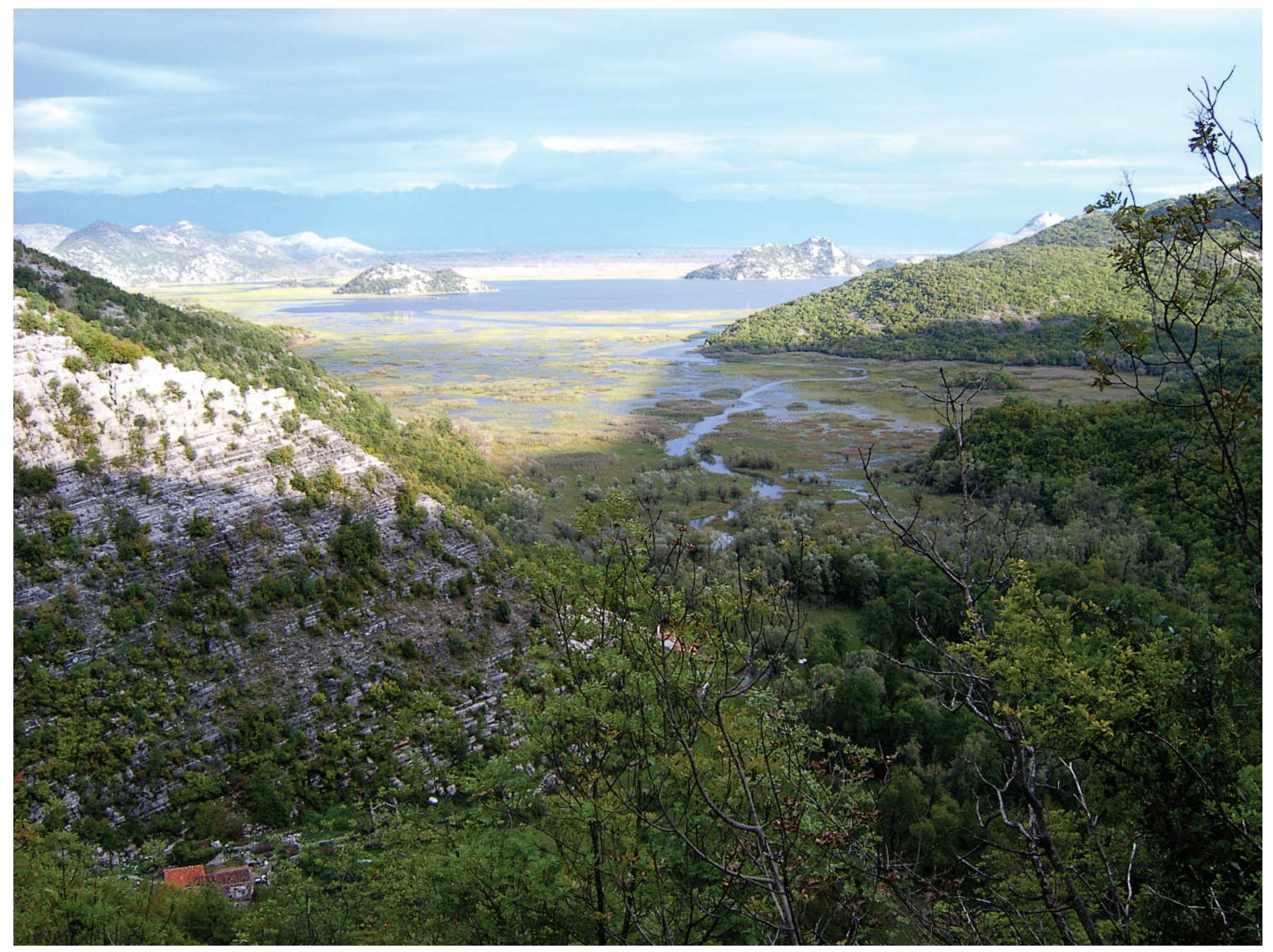

Fig. 5 - Lake Skadar (By Günter Wondrak; via Wikimedia Commons). 
In Romania, the subspecies was reported present in the delta of the River Danube since 1896 (Dombrowski, 1910) as well as in Slatina (Oltelia) (Reiser, 1894). Further south, in Dobruja, the taxon was reported absent up to the end of the 1800s (Almasy, 1898) and in the early years of the 20th century (Keve, 1978).

In Bulgaria, the Black-headed Yellow Wagtail was relatively common as a breeding species in Sofia (in urban areas and especially in the wetlands to the south of the city), in areas to the south and in Varna Province; it was a rather rare nesting bird in Kàrlovo, Plovdiv and Kara (Reiser, 1892; Jurkiewicz, 1904; Cãtuneanu et al., 1962).

To the east, the Black-headed Yellow Wagtail was present in Bessarabia (today, this area coincides with the boundary between the Republic of Moldova and the Ukraine), in the Kherson Oblast (Moskalenko, 2015), in the Crimean peninsula and in southern Russia (Reiser, 1894; Naumann, 1897; Prazák, 1897; Olphe-Galliard, 1890; Jurkiewicz, 1904).

In European Russia, it was present in the Caucasus (Bogdanow, 1879), in particular on the northern slopes of Kislovodsk (Lorenz T., 1887; Radde, 1899) and in the Orenburg Oblast (Zarudny, 1888; 1897). It appeared sporadically in the Meshchora Region of central European Russia in summer 1899 (Khomyakov, 1900; Ananeva et al., 2008).

Its presence in Italy was scarce and irregular, being more frequent in Sicily, Apulia, Marche, Tuscany and Liguria (Salvadori, 1872; 1886; Arrigoni degli Oddi, 1902). Arrigoni degli Oddi (1898) cites two males captured in Veneto in 1892, respectively in Valle Zeppa on 18 May and in Monselice on 15 August; eight other specimens present in his ornithological collection came from Apulia and Campania. The hypothesis that the bird was nesting in the Madonie mountain range of Sicily (Doderlein, 1871; Dresser et al., 1871-1881; Salvadori, 1872; 1886) was not confirmed by an investigation by Giglioli Hillyer (1890).

In 1983, Ardoino considered the Black-headed Yellow Wagtail to be a rare migratory bird on the islands of Malta and Gozo (Despott, 1928).

In Switzerland, the subspecies appeared occasionally during the migration period on the shores of Lake Geneva and Lake Neuchâtel, as well as in the Canton of Grisons and the Canton of Ticino (Fischer Sigwart, 1892). Its presence was similar in Carinthia (Keller, 1890). However, these reports have possible issues over confusion with thunbergi.

\section{Middle East}

In Turkey, the Black-headed Yellow Wagtail was common in the summer around Smyrna (Krüper \& Hartlaub, 1875), nesting in the surroundings of Istanbul (Dresser et al., 1871-1881), and in the province of Ardahan (Sharpe, 1885). In the Caucasus, it was reported north of Yerevan in Armenia (Radde, 1884), and along the banks of the River Kura in Azerbaijan (Dresser et al., 1871-1881). Satunin (1907) reported the bird nesting along the coast of the Caspian Sea at Lankaran and in wet meadows near the village of Kialviaz (Lerik District, Azerbaijan) at an altitude of about $2100 \mathrm{~m}$ a.s.l.
The Black-headed Yellow Wagtail was reported nesting in Persia (Heuglin, 1869; Dresser, 1902), probably in the north-western sector, as reported by de Filippi (1865), and certainly at the foot of Mount Sabalan, in Ardabil Province, up to 1,800 m.a.s.l. (Radde, $1884 ; 1886$ ); it was also present in Shiraz and Aspas (Fars Region) in 1870-72 (Blanford, 1876). Blanford also cites specimens attributable to melanogrisea present in Baluchestan (south-eastern Persia), but this was based only on observations made in spring (March).

The subspecies was present on Cyprus (Müller, 1879; Lilford, 1889). With regards to Palestine, although Heuglin (1869) considered the Black-headed Yellow Wagtail nesting in that area, Tristram (1884) affirmed that it was only present in small numbers during the winter migration.

As for the period 1830-1865, several authors reported breeding of the Black-headed Yellow Wagtail in Nubia and in Upper Egypt in general, but this information is contradicted by works expressly dedicated to this region (Shelley, 1872; Gurney, 1876; Schrader, 1892).

\section{Central Asia}

The subspecies was considered a widespread breeding bird in the Volga Delta and along the coast of the Caspian Sea (Zarudny, 1888; 1897) in Turkestan (Kazakhstan, Kyrgyzstan, Tajikistan, Turkmenistan and Uzbekistan) (Dresser et al., 1871-1881) and, in particular, in the areas surrounding the Aral Sea (Homeyer, 1878; Olphe-Galliard, 1890) and Bukhara (Uzbekistan) (Floericke, 1897). In Turkmenistan, it was common near the Merv and Pinde Oasis (Mary Region) and further south along the River Murghab; it was frequently observed at the mouth of the River Atrek (Zarudny, 1889) and along the River Hari (Ahal Province) (Radde \& Walter, 1890). It was present in the breeding season near Zaysan, eastern Kazakhstan (Tarbagatai Mountains, between Kazakhstan and China, 1200-1500 m a.s.1.), in the Altai Mountains and further south in Almaty Province (Finsch, 1879; Homeyer \& Tancre, 1883).

It was common in Afghanistan in the spring: although Swinhoe (1882) did not explicitly mention it nesting there, John (1889) - referring to data collected in 1878 and 1879 - stated that some pairs were nesting near Kandahar.

In China, Sharpe (1891) - citing information provided by Stoliczka - considered it possibly nesting in southwestern Xinjiang. In neighbouring Kashmir, the Blackheaded Yellow Wagtail appeared only during migrations (Oates, 1890).

The breeding range of feldegg known for the period 1866 to 1900 is shown in Fig. 6.

\section{From 1901 to 1945 Europe}

In Greece, the Black-headed Yellow Wagtail was widespread in the northern part of the country, along the coasts and islands of Attica, the Peloponnese, Epirus, Acarnania, Thessaly, Macedonia and Euboea (Reiser, 1905; Jourdain 1906; Kattinger, 1934; 1935; Kleiner, 1936), on the Cyclades (especially on Lesvos, Kos, Folegandros and 


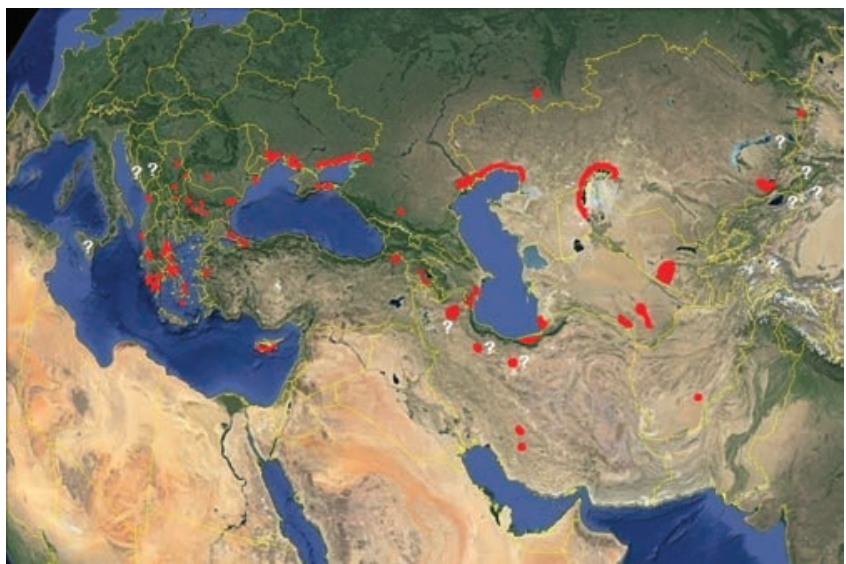

Fig. 6 - In red, the 1866-1900 breeding range of Motacilla flava feldegg. The white question marks indicate doubtful sites.

Santorini) (Wellstein, 1938) and on Rhodes (Sassi, 1937; Wellstein, 1938). On Crete, it was only migratory (Stresemann, 1943; Hafemann, 1967). It was observed breeding in European Turkey (Hartert, 1910; Buchner, 1922), but in small numbers (Stresemann, 1920).

In Bulgaria, it was relatively common in the south, along the Black Sea coast, in the Kamchia Valley and in the district of Sofia; however, it avoided the mountainous areas, becoming scarce in the Danube Valley (Jurkiewicz, 1904; Jourdain, 1906; Hartert, 1910; Harrison, 1933). The latter indication was questioned by Kleiner (1936), who did not encounter the subspecies during a trip to the area. It was common in south Serbia (Lintia, 1917) and in Macedonia (Kleiner, 1936; Kattinger, 1942).

In Romania, the Black-headed Wagtail was nesting in the early 1900s in the Danube Delta; in the rest of the country, it was scarce and present only as a migratory species (Dombrowski, 1910). Lintia (1909) observed some individuals in early May 1908 in Braila, near Lake Dulce, and Schenk (1917), defining it as a rare bird in Transylvania in the spring; some individuals were reported migrating in early April 1933 and in 1947 (Cãtuneanu et al., 1962).

In the Czech Republic, a male was reported on 2 June, 1928, in Blatna (southern Bohemia) and four nesting pairs were recorded the following year in Náměšt’ nad Oslavou (Vysočina) (Kleiner, 1936). However, possible confusion with intermediate forms of dombrowskii having particularly intense colouration casts a doubt on the validity of these reports (Kleiner, 1936). In Hungary, the subspecies appeared in the spring and autumn, but it did not nest there (Schenk, 1918; 1939-1942).

Although more abundant in the eastern part of the Balkans, the Black-headed Yellow Wagtail was present in the northern part of Lake Skadar and along the coast of Montenegro (Jourdain, 1906; Schenk, 1917), but absent in the Bay of Kotor (Roháček, 1919). Southern Dalmatia was generally considered a nesting area by a number of authors (Jourdain, 1906; Hartert, 1910; Stresemann, 1920), but there was no real evidence of breeding; nevertheless, the subspecies was a regular visitor in the migration period (Hirtz, 1914; Maštrović, 1942).
The Black-headed Yellow Wagtail nested in the southern steppes of the Ukraine (Moskalenko, 2015), along the northern edge of the Black Sea, in the Astrakhan Oblast and the Crimea (Jourdain, 1906; Molchanov, 1906; Dombrowski, 1910; Ramsay, 1923; Buturlin et al., 1940), and in the Orenburg Oblast (Dementiev, 1937). It was present at Pavlograd in small numbers (Dnipropetrovsk), and in July 1905 a male was observed in the valley of the River Orchik (Kharkiv) (Dementiev \& Gladkov, 1954); at the end of April 1910, a pair was observed probably nesting in Mityakinskaya (Rostov) (Averin, 1911), and between 20 May and 2 June, 1919, Scrjabin reported individuals along the coast of the Azov Sea, between Taganrog and Rostov (Aksyonov \& Ermakov, 2014).

In Italy at the beginning of the 1900s, the Black-headed Yellow Wagtail appeared regularly during the migration period only in Apulia and on the eastern coast of Sicily, but was rare elsewhere, including Lazio and northern regions (Picchi, 1904; Whitaker, 1905; Vallon, 1907; Giglioli Hillyer, 1907; Patrizi-Montoro, 1909). Picchi (1904) and Whitaker (1905) reported that, according to Dr. Minà Palumbo, the subspecies was present in the summer along the waterways of the Madonie (Sicily), indicating that the area was used for breeding; however, Giglioli Hillyer (1907) casted doubts on this, as he had done 17 years before, with Arrigoni degli Oddi (1929) ascertaining that the reports needed confirmation.

During the migration period, the Black-headed Yellow Wagtail was a rare appearance in many areas of Europe. In England, a male was captured for the first time near Willingdon, Sussex, on 13 May, 1903 (Ticehurst, 1903). Other sightings in the UK followed: a male was reported in Lydd (Kent) on 3 June, 1908; a male was captured at Winchelsea (Sussex) on 23 May, 1909 (now kept at the Museum of Brighton); a male was reported in Romney (Sussex) on 26 May, 1909; an individual was probably seen in Norfolk on 17 and 19 June, 1910, and another one captured at Pevensey (Sussex) on 25 May, 1912 (skin kept at the Royal Museum of Scotland, Edinburgh) (Harters et al., 1912; British Ornithologists' Union, 1915; Evans, 1916; Witherby, 1920; Collinson \& McGovan, 2011).

Individuals were observed in southern Switzerland (Fatio \& Studer, 1913), in eastern Galicia (Poland/Ukraine) (Hoyer, 1910), in Silesia (Poland) in 1925 (Natorp, 1925; Niethammer, 1942; Keve, 1961), in Pomerania (Poland) in May 1926 (Robien, 1928), in Bohemia on 2 June, 1928, in the Camargue (France) (two males) on 30 April, 1928 (Mayaud, 1936; 1940), in Moravia on 20 May, 1929 (Svoboda \& Černý, 1946), in Styria (Austria) (Niethammer, 1940), in Welser Heide (Upper Austria) in 1932 (Rohrhofer, 1932; Keve, 1961) and in France (a young individual) on 6 May, 1933 (Mayaud, 1936; 1940). Apart from the specimens preserved at museums, the sightings have possible issues over confusion with thunbergi.

\section{Middle East}

In Turkey, the Black-headed Yellow Wagtail was common near Istanbul and Izmir (Jourdain, 1906; Braun, 1908); near Ankara, it was deemed to be a spring migratory species (Kummerlöwe \& Niethammer, 1934). It was 
present in the Caucasus, particularly widespread along the coast of the Caspian at Lenkoran in Lerik District (Azerbaijan) (Satunin, 1907; Buturlin et al., 1940). It nested in the surroundings of Aleppo, Syria (Clarke, 1924), but in Palestine it was considered only migratory (Luke \& Keith-Roach, 1922).

In Persia, Witherby (1903) reported the discovery of a nest with eggs at Shiraz (Fars Region), at about 1,5001,600 m a.s.l., on 3 May, 1902; a month earlier, he reported the start of egg laying about $60 \mathrm{~km}$ further west, in Dasht-e-Arjan (Fars Region), probably in the vicinity of Lake Perishan. The subspecies was breeding in the north-west of the country, in Zagros Region, along the southern coast of the Caspian Sea, in the eastern region of Khorāsān, in the mountains bordering Afghanistan, in the northern part of Sistan and Baluchestan, and in Kerman Region (Witherby \& Woosnam, 1907; Zarudny, 1911). The widespread presence of the Black-headed Yellow Wagtail in western Persia was confirmed in 1935 (Paludan, 1938) and in the valley of the River Lar, in the Alborz Mountains north of Tehran, in 1943-44 (Trott, 1947).

In Iraq, on the basis of data collected in July 1917, the bird was assumed to be breeding close to Baghdad and near the Hindiya Dam (Governorate of Babil) on the Euphrates; specimens were collected about $60 \mathrm{~km}$ from Basra on 26 June, 1917, and a male in breeding plumage was observed in the southern marshes of Iraq on 12 July of the same year (Ticehurst et al., 1922).

In Egypt, the presence of the subspecies was confirmed only during the migration period (Nicoll, 1919).

\section{Central Asia}

In Kazakhstan, the Black-headed Yellow Wagtail nested in the north-west, especially in Shalkar District (Aktobe) (Suschkin, 1914; Buturlin et al., 1940) and in the Mangyshlak Peninsula (Dementiev \& Gladkov, 1954); it was also present in the Aralo-Caspian region shared with Uzbekistan (Suschkin, 1914), in the northwestern part of the Aral Sea and in the Little Barsuki Desert (Grote, 1928). It was reported nesting in Turkestan, but without detailed indications (Sushkin, 1914; Ticehurst, 1922; Stuart Baker, 1926). In Turkmenistan, a male captured by Bonn in Ashgabat on 15 May of an unspecified year of the early 1900 s was kept at the "Alexander Koenig" Zoological Museum (Harms, 1909; van den Elzen, 2010). The Black-headed Yellow Wagtail nested in the northern Kazakhstan Steppe up to Irgiz and Chelkar-Tangiz (Sushkin, 1908), and was also reported along the northern shore of Lake Balkhash (Dolgushin, 1940 ) and at the confluence of the River Irtysh with Lake Zaysan (Kökpektí) (Sushkin, 1938). It nested along the southern margin of Tajikistan, along the Surkhan and Kafirnigan rivers, near Mikoyanbad, from Pyandzh to Chubek (Ivanov, 1940) and to the east along the River Ili up to Yining (Ili Kazakh Autonomous Prefecture, Xinjiang, China) (Dementiev \& Gladkov, 1954). It was also present in Kandahar (Afghanistan) (Ticehurst, 1927).

The breeding range of feldegg known for the period 1901 to 1945 is shown in Fig. 7.

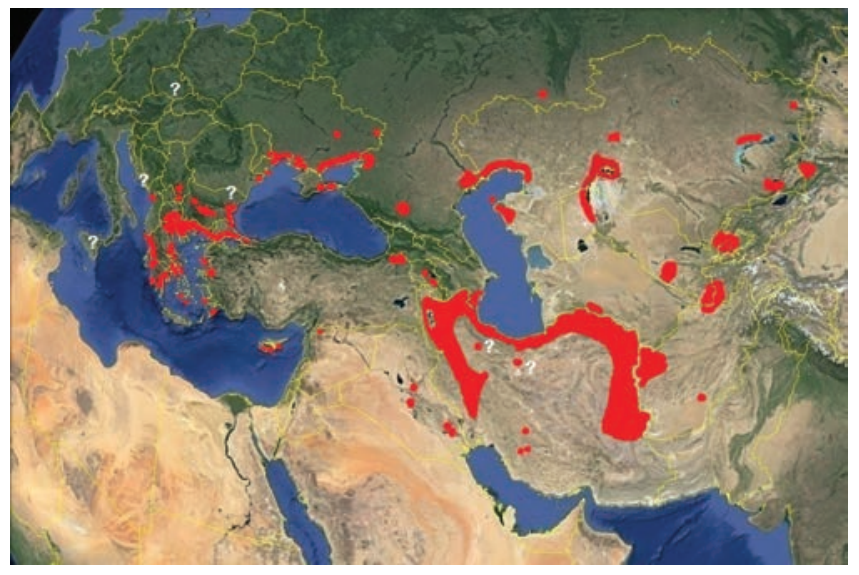

Fig. 7 - In red, the 1901-1945 breeding range of Motacilla flava feldegg. The white question marks indicate doubtful sites.

\section{From 1946 to 1980 \\ Europe}

In the Balkans, the Black-headed Yellow Wagtail nested from southern Dalmatia (Mayr \& Greenway, 1960) and southern Serbia (in the Great Morava Valley) (Makatsch, 1952-55; Keve, 1958) to central-south and eastern Bulgaria (Patev, 1950; Mayr \& Greenway, 1960; Cãtuneanu et al., 1962), and also further south to Montenegro, Albania and Greece (Grant \& Mackworth-Praed, 1952; Mayr \& Greenway, 1960). In Greece, it was reported in Thrace, Porto Lagos, the Evros Delta (Ganso, 1962) and in central Macedonia (Vardar Delta) (Makatsch, 195051). Its presence nesting on Corfu was confirmed in 1953 (Böhr, 1962) and in 1966 (Hellebrekers et al., 1969). In 1963, possible breeding sites included the island of Karpathos (Kinzelbach \& Martens, 1965). It was known in the summer on Lésvos, Folegandros, Kos, Santorini and Rhodes (Kinzelbach \& Martens, 1965), but was only migratory on Crete (Stresemann, 1956; Hafemann, 1967). In Albania, it was very common near Lake Skadar (Reichholf, 1977). In the late 1940s, it was ascertained nesting in the Vardar Valley near Skopje (Republic of Macedonia) (Karaman, 1949). Its presence in Macedonia was also confirmed in 1968 (Simon, 1969-1971).

In Romania, the Black-headed Yellow Wagtail appeared again during spring migration in 1951 and 1953 (Cãtuneanu et al., 1962). A nest with five chicks was reported in June 1956 at Lake Techirghiol (Dobrogea), and the following year breeding was determined at Vasilați (Muntenia); in 1958, it was reported nesting along the Black Sea (Dobrogea) (Cãtuneanu et al., 1962). In 1959, individuals were observed in wetlands during the spring migration, and a nest was found in Gălbinași (Muntenia); from 1959 to 1961, it was reported nesting in Banat Region (Talpeanu, 1967). In 1960, the Black-headed Yellow Wagtail was discovered nesting in southern Oltenia, near the Danube, and in 1961 a young, just-fledged specimen was caught northeast of Bucharest (Cãtuneanu et al., 1962). In 1962, is was reported as migratory in the Danube Delta (Vasiliu, 1966), and in 1966 a nest was found in Oradea and three pairs nesting in Mureş County (Transylvania) (Talpeanu, 1967; Szabó, 1974). In the latter area, a couple of nests 
were found also the following year (Szabó, 1974). Nests were sighted in the same locations also in the late 1970s (Talpeanu \& Paspaleva, 1981). Breeding sites in Oltenia were established in 1972 at Craiova and Drăgăşani (Anonymous, 1979).

In 1953, a male feldegg was reported nesting in Baska, on Krk (Kvarner Islands, Croatia), and in 1955 a pair was sighted nesting at the mouth of the Mirna River in Istria (Kroneisl-Rucner, 1960). In 1957, as many as 15 pairs were sighted in Pancevo (Vojvodina, Serbia) (Pelle, 1957).

In the early 1970s, feldegg nests were found in Serbia, southern Dalmatia, southern Montenegro and Macedonia (Matvejev \& Vasić, 1973; Stumberger et al., 2008).

In Hungary, the Black-headed Yellow Wagtail was observed at Lake Kis-Balaton (southern Pannonia) on 19 April, 1953 (Warga, 1952-55; Keve, 1976), and on 14 May, 1954, it was reported in the north-eastern suburbs of Budapest (Doming, 1952-55). In June 1955, it was supposed to be nesting in Szeged (Southern Great Plain) due to the presence of a territorial male (Beretzk, 1956-57). On 4 April, 1968, a male appeared for the first time in Baranya Province (southern Transdanubia) (Molnár, 1969-70; 1976). An individual was observed on 9 April, 1974, in Eger (northern Hungary) (Csörgő, 1975); the same year, a nest was reported at Szécsény (northern Hungary), in the basin of the River Ipel (Moskat, 1975), and another with five chicks was found at Hortobágy (Szabó, 1975). In 1978, a breeding pair was reported in Hajdu-Bihar Province (Northern Great Plain) (Gabor, 1981).

In Italy up to the late 1950s, the Black-headed Yellow Wagtail was considered a not rare, albeit non-breeding, species in eastern Sicily and Apulia during the spring migration, but rare elsewhere (Caterini \& Ugolini, 1953; Martorelli, 1960). However, by the end of the next decade the bird was reported nesting in Apulia (Cova, 1969), and within a few years also in Tuscany, Lazio and Abruzzo (Brichetti, 1976a; Moltoni \& Brichetti, 1976). The first breeding pair was found at Saline di Cervia (Ravenna, Emilia-Romagna) on 4 July, 1958; two more pairs were reported south of Zapponeta (Foggia, Apulia) on 12 July, 1961; other sighting included a pair at Lake Lesina (Foggia, Apulia) on 5 June, 1970 (Foschi, 1976), and a probably nesting pair at Orbetello Lagoon (Grosseto, Tuscany) in the early 1970s (Moltoni, 1975). In Tuscany, other nests were reported in Piombino (Livorno) on 5 May, 1977, and in the southern part of the Park of Migliarino (San Rossore, Massaciuccoli, in the municipality of Pisa) in May 1977 and 1978 (Meschini, 1981). In 1977, a couple of nests were reported at Lake Caprolace (Latina, Lazio) (Fraticelli, pers. comm.). Brichetti (1976b) highlight the increased regularity with which the taxon was appearing in the Po Valley.

On 2 May, 1962, a male was observed in Germany in Pleidelsheim (Baden-Wurttemberg) (König \& Schwammberger, 1963).

In Austria, after sightings in spring 1964 (Vorarlberg) and 1965 (Burgenland) (Leisler, 1968), a Black-headed Yellow Wagtail was reported in Carinthia on 1 May, 1968 (Woschitz, 1968), and in Waldviertel (Lower Austria) (Ganso, 1968). Of note, the first breeding pair was sighted in the Rhine Delta (Vorarlberg), an event that was repeated the following year (Blum, 1968; 1970), and another in
Güssing (Burgenland) (Samwald, 1968). In spring 1967 and 1968, a male was observed near Innsbruck (Tyrol, Austria) (Myrbach, 1968). Appearances were reported at Lake Neusiedl (Burgenland) in the spring of 1965, 1966 and 1968 (an isolated male); an individual was also reported on 13 June, 1968, but there was no evidence of breeding (Homes, 1966; Duda \& Leisler, 1968).

In Switzerland, a specimen was observed in the Canton of Zurich on 19 April, 1945, but no further sightings were reported at least until 1963 (Schinz, 1964). Nests were found in Canton Ticino in 1967 (Schifferli, 1968). In the Rhine Delta (Lake Constance), various breeding pairs were recorded: two pairs in 1970 and one in 1974 (Schuster, 1983). In spring 1974, a male was reported in a sand quarry in Bavaria (Germany) (Reinsch, 1975); others were sighted in Styria (Austria) in 1973 and 1974 (Samwald, 1975; Stani, 1975) and on 1 April, 1974, in the upper valley of the River Mur (Präsent, 1977). In the same year, the Black-headed Yellow Wagtail was found nesting for the first time at Lake Zell (Salzburg) (Winding, 1974). On 19 April, 1975, it appeared at Lake Chiemsee (Bavaria) (Reichholf-Riehm, 1976), and was again ascertained nesting in Salzburg (Austria), at Lake Zell (Winding, 1975; Lindenthaler, 1980). After many spring appearances, a first breeding pair was located at Lake Neusiedl (Burgenland) (Aschenbrenner, 1975). On 18 April, 1976, a male was observed in Carinthia (Feldner, 1979), while a sighting at Lake Zell was confirmed in the summer (Winding, 1979). Further sightings were made in April 1977 in Styria (Stani, 1978) and Carinthia (Wruss, 1978), and a successfully breeding male was seen at Lake Faaker (Carinthia) (Wagner, 1977; Wruss, 1977). In April 1978, a male was photographed at St. Georgen ob Judenburg (Styria) (Hable, 1978), and two specimens were reported in Carinthia (Wruss, 1979). In spring the following year, new observations were recorded in Styria (Stani, 1980).

In France, the birds' presence was very scarce during migrations (Mayaud, 1952). After 41 years of absence, a male appeared at Hyères (Provence-Alpes-Côte d'Azur) in April 1974. Up to 1980, there were nine observations on a total of ten individuals in France (CHN, 2015). In 1980, a male, likely paired with a flava female, was found nesting for the first time in France, at Montereau-FaultYonne, in the Seine et Marne Department (Ile-de-France) (Tostain \& Siblet, 1981; Siblet \& Tostain, 1984).

In the Ukraine in the 1970s, nests were observed at Chernivtsi Oblast (Buchko et al., 1996), on the southern steppes (south of the city of Kherson) and the Crimea (in Opuk, along the east coast) (Frank, 1950; Havrylenko et al., 2014; Moskalenko, 2015). The breeding range extended south to Krasnodar and Stavropol (northern Caucasus) (Dementiev \& Gladkov, 1954; Peklo \& Til'ba, 2007) and then east to the steppes of the Astachan Oblast and the mouth of the Volga, and to the coast of the Caspian Sea, south of the Caucasus (Dementiev \& Gladkov, 1954; Mayr \& Greenway, 1960). Its presence in Orenburg Oblast was confirmed again (Gavrilov, 1970). On 16 May, 1979, a wandering individual reached the "Mykhaylivska Tsilyna" Natural Reserve (Sumy) in north-east Ukraine (Lebed, 1996).

In the mid-1950s, the intergradation area of feldegg and cinereocapilla was positioned in the northern part of 
Dalmatia, Herzegovina and Serbia, but some intermediate individuals were found more south, in northern Albania (Vaurie, 1957; Mayr \& Greenway, 1960). Instead, near Belgrade, south along the Danube, in Dobruja and in southern Ukraine, feldegg was intergraded with the nominate subspecies flava (Vaurie, 1957; Mayr \& Greenway, 1960). In the $1970 \mathrm{~s}$, there were intermediate flava $\mathrm{x}$ cinereocapilla $\mathrm{x}$ feldegg populations in Herzegovina, in southern Dalmatia and southern Montenegro, as well as flava x feldegg (dombrowskii) populations in Negotin (north-east of central Serbia) and locally in the south of Montenegro (Matvejev \& Vasić, 1973; 1977).

In the Czech Republic, sightings were reported in Třeboň (south Bohemia) on 22 May, 1976 (Sedláèek \& Horáèek, 1983), and 4 July, 1979 (Přibil, 1983).

An individual was observed in southern Poland on 19 May, 1959 (Bochenski, 1960), and in spring 1977 (Tomiałojć, 1990).

In Scotland, a male perhaps attributable to the subspecies was observed on the Shetland Islands between 8 and 11 May, 1969 (Robertson, 1970-71) and on Fair Isle on 7-9 May, 1970 (Forrester et al., 2007).

In Finland from 1953 to 1980 , five specimens were recorded durind the months of May and June (BirdLife Finland, 2015).

\section{Middle East}

In addition to the ranges already known in Istanbul and Izmir, the Black-headed Yellow Wagtail was present in central Turkey near Lake Mogan (central Anatolia), in the valley of the River Skarya and in the Kizilirmak Basin; to the east, it was widespread in Trabzon Province and in the surroundings of Erzurum (Kumerloeve, 1961; Spitzer \& Ganso, 1967). Regarding southern Turkey, Makatsch reported finding eggs at the estuary of the Seyhan on 20 May, 1957; other sightings were made in Birecik (Şanliurfa) (Kumerloeve, 1961).

The bird was also found nesting on Cyprus (Kinzelbach \& Martens, 1965).

In Israel, the first ascertained nesting concerned eight pairs in the Hula Valley (meadows in Nahal Enan) in 1951 (Zahavi, 1957); breeding was then confirmed at the valley also in May 1954 (Meir, 1956-57).

In Lebanon, the Black-headed Yellow Wagtail was sighted for the first time in summer at the beginning of the 1960s (Kumerloeve, 1962), and in 1974 a pair was found nesting in wetlands near Aammiq (Macfarlane, 1978). It was probably breeding in southern Iraq and in Syria along the Euphrates (Grant \& Mackworth-Praed, 1952; Allouse, 1953; Moore \& Boswell, 1957; Mayr \& Greenway, 1960). It was certainly nesting in Iran (Grant \& Mackworth-Praed, 1952; Mayr \& Greenway, 1960): in particular, its presence was confirmed in the River Lar valley (in the Alborz Mountains, north-east of Tehran) in the second half of the 1940s (Meiklejohn, 1948), and in June 1958 an adult male and a young individual were observed in Varamin (60 km south-east of Tehran) (Diesselhorst, 1962); in the 1970s it was common in the wetlands near Lake Urmia (northwestern Iran) (Scott D., 2001). A male was spotted in Zahedan (Sistan and Baluchestan) on 6 June, 1975, in an area of irrigated cultivation at about
1350 m.a.s.l. (Desfayes \& Praz, 1978). The presence of the subspecies in Sistan was already known in previous decades (Dementiev \& Gladkov, 1954).

In Egypt, it appeared most frequently in the autumn during the migration period, but only rarely in the valley and delta of the Nile (Hoogstraal et al., 1961).

\section{Central Asia}

The Black-headed Yellow Wagtail was widespread in the Volga Delta, along the shores of the Caspian Sea (Gavrilov, 1970), and in the Mangyshlak peninsula (Kazakhstan) and offshore islands (Dementiev \& Gladkov, 1954). To the east was an extensive breeding area that included the Kazakhstan Seppes, the Aral Sea, the Syr Darya valley, the eastern part of the Kyzyl Kum Desert, the inferior portions of the Irgiz and Turgai valleys, from Turkmenistan to Semirechia (southeast Kazakhstan), and to the north up to the Tarbagatai Mountains, although in this area the subspecies was rare (Dementiev \& Gladkov, 1954; Grant \& Mackworth-Praed, 1952; Dolgushin et al., 1970). Further south, the Black-headed Yellow Wagtail nested along the northern coast of Lake Balkhash, in the Ili Valley, at the foot of the Tian Shan Heights, near Lake Alakol and in the Chuy Valley (Grant \& Mackworth-Praed, 1952; Vaurie, 1957; Mayr \& Greenway, 1960; Dolgushin et al., 1970).

The Black-headed Yellow Wagtail appeared sporadically during the breeding season also in Tengiz-Korgalzhyn District (Aqmola). Two sightings are known for central Kazakhstan: one made in May 1961 and one on 18 May, 1969, but no proof of breeding was given (Heinicke et al., 2006).

In Uzbekistan in 1974 and 1975, the bird was reported north of Bukhara, south-east of Samarkand, in Kizylkum, in Karakum and along the River Tschirtschik, north of Tashkent (Wüst, 1976).

In Tajikistan, the subspecies was nesting in the southwest of the country (Ivanov, 1969), whereas in Afghanistan it was an uncommon breeder in the western and north-western portions of the country (Paludan, 1959; Sayer \& van der Zon, 1981).

The breeding range of feldegg known for the period 1946 to 1980 is shown in Fig. 8.

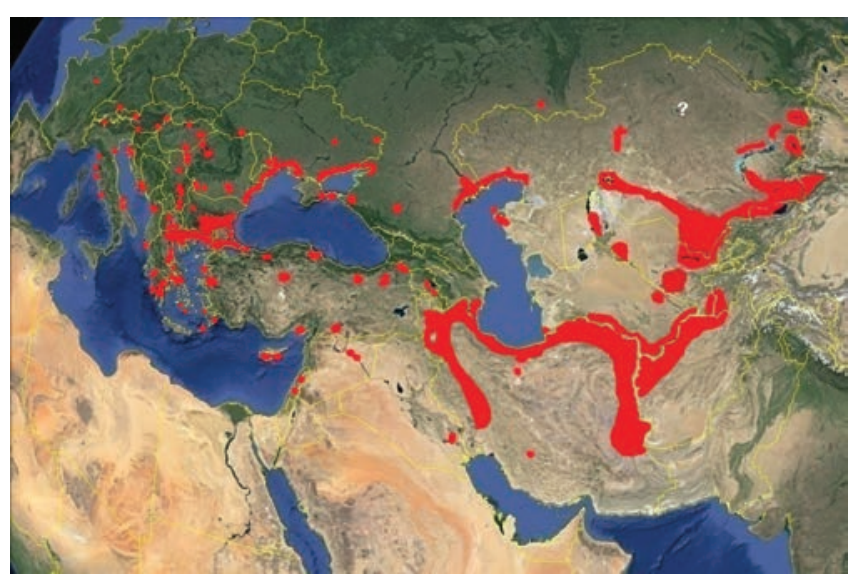

Fig. 8 - In red, the 1946-1980 breeding range of Motacilla flava feldegg. The white question mark indicates a doubtful site. 


\section{From 1981 to 2015 \\ Europe}

In Greece, the Black-headed Yellow Wagtail was present on the Thessaly Plain near Lake Karla, in southern Viotia and around Gialova Lagoon (Messinia) (Gerakis, 1992; Vlacos et al., 2013). It appeared during the migration season on the Cyclades in 1984-86, but did not nest there (Magioris, 1987). However, it was nesting in the Thyamis Delta (Epirus) (Economidou et al., 1993). A summary of the birds' distribution in Greece is provided by Handrinos \& Akriotis (1997).

The subspecies was common around the mouth of the River Bojana, on the border between Montenegro and Albania; in spring 2003, at least 71 pairs were surveyed (Stumberger et al., 2004; Schneider-Jacoby et al., 2006a). It was also nesting in the wetlands of Karavasta Lagoon (Albania) (Miho et al., 2013).

In Croatia, there were 500-1000 pairs concentrated in central and southern Dalmatia (Lukač, 2007).

In Bosnia-Herzegovina, it was present - together with cinereocapilla - at Livno, on the karst plateau at about 720 m.a.s.l. (Schneider-Jacoby et al., 2006b).

The subspecies was nesting at Lake Gruža (Ružić et al., 2006) and probably around Čačak (central Serbia) along the West Morava (Ružić \& Pantovic, 2007). In 1994-2005, at least 100-200 pairs were nesting in the wetlands of the Pešter Plateau (1150 m a.s.l.) (Institute for Nature Conservation of Serbia, 2006).

In Bulgaria, it was common during the breeding season in Tazha (Stara Zagora), nesting in the wetlands of Aldomirovtsi, Dragoman, on the border with Greece near Lake Kerkini (Morris, 2011) and the Srebarna Natural Reserve (3 pairs $\left./ \mathrm{km}^{2}\right)$ (Kambourova, 2012).

In Romania, the Black-headed Yellow Wagtail was breeding in the valleys of the Fagaras Mountains (Transylvania) (Hoeser, 2000) and at the confluence of the Cricovul Dulce and Ialomita (Prahova) (Chişamera, 2007); in the latter location, it was the only subspecies of Motacilla flava present. It was also nesting in the Danube Delta (Boscain \& Biasioli, 2014).

InHungary,itwasreportednestingatHódmezővásárhely (Southern Great Plain) in 1995 (István, 1995).

In Slovenia in the early 1990s, it was nesting in the marshes around Ljubljana (Bozic, 1996), but perhaps it was already present in the area since the mid-1970s. In 1997, it was nesting in a cultivated area of Oltredrava and Styria, where flava and cinereocapilla were also present (Vogrin, 1998; Vogrin \& Miklie, 2004). Research conducted in the wetlands of Cerknica (Littoral-Inner Carniola) in 2000 revealed an only marginal presence of the Blackheaded Yellow Wagtail (168 pairs of cinereocapilla and only one of feldegg) (Kus-Veenvliet, 2001). In the area around Sečovlje, feldegg was regularly nesting with cinereocapilla (Škornik, 2012).

In Italy, the Black-headed Yellow Wagtail was still considered a rare migratory bird, although less so in eastern Sicily and Apulia, with nesting sites in the centresouth (Toschi, 1986; Brichetti et al., 1986; Autori Vari, 2008). In 1981, four pairs were reported breeding in the swamp at Frattarolo (Manfredonia, Foggia, Apulia) (Cambi, 1982), and in June 1985 a pair was observed in
Serracapriola (Foggia, Apulia) (Brichetti, pers. comm.). Nesting was also confirmed in 2000 in the Province of Foggia (Apulia), including on the Gargano Promontory (Liuzzi et al., 2013). Specifically for this geographical location, nesting sites were detected at Lesina in June 2011 (Tatino, pers. comm.) and probably in Manfredonia (Foggia) in June 2012 (de Rosa, pers. comm.). In Sicily, the bird was reported nesting irregularly at the salines at Trapani, at ponds in Longarini, Cuba and Vendicari, at ponds in Baronello, at the salines of Syracuse and at the mouth of the River Simeto, forming sometimes mixed couples with cinereocapilla (Corso, 2005; Brichetti \& Fracasso, 2007; Autori Vari, 2008). At the salines at Trapani, a probable nesting site was reported in May 2015 (D'Amico, pers. comm.). In May 1994, the bird was found nesting along the Adriatic coast in Mondolfo (Pesaro and Urbino, Marche) (Poggiani \& Dionisi, 2002), as well as on the Abruzzo Apennines (Santone, 1994). In Molise, adults with beakfulls of food were seen at the mouth of the River Biferno (Campobasso) from 2010 to 2014, and a nesting site was ascertained in Campomarino (Campobasso) in May 2014 (de Rosa, pers. comm.). In Tuscany in 20062015, there were up to five pairs in the Diaccia Botrona Marsh (Castiglione della Pescaia, Grosseto) (Fig. 9) (Giovacchini \& Stefanini, 2015a; 2015b). In northern Italy, it was reported nesting in 1986 in Santa Lucia di Piave (Treviso, Veneto) (Mezzavilla, 1989), and in May 1989 on the island of Cona (Gorizia, Friuli-Venezia Giulia) (Parodi, 1999); a probable nesting site was reported in San Michele al Tagliamento (Venice, Veneto) in May 2012 (Sgorlon, pers. comm.).

In Austria, the Black-headed Yellow Wagtail was reported again at springtime: in 1981 in Styria (Hable, 1983 ) and Burgenland (Laber \& Ranner, 1997), and in 1984 in Upper Austria (Petz, 1984) and Styria (Laber \& Ranner, 1997). In Germany, a pair was observed in Grabenstätt (Bavaria) on 18 May, 1985 (Deutsch, 1985). Up to the mid-1980s, there were six known sightings in Bavaria (three in lower Franconia, one for central Franconia and two around Lake Chiemsee) (Wüst, 1986). In 1984, it was reported nesting in Baden-Württemberg (Südbeck et al., 2007). In Bavaria, there were two distinct records, in spring 1992 and on 16 April, 1995, of an individual flocking with other wagtails near the River Salzach (Deutsch-Reitinger \& Frank, 1996). In 1985 in the wetlands of Furtner Teich, two nesting pairs (one in Styria and one in Carinthia) were recorded at about 930 m.a.s.l. (Brunner, 1986; Wruss, 1986; Lazowski, 1997; Hable et al., 1999). In 1988, a pair was seen nesting in Villach (Carinthia) (Laber \& Ranner, 1997). In 1990, the subspecies was observed migrating in eastern Austria (Zuna-Kratky, 1990). In the period 1991-1995 in Austria, there were 15 reports on a total of 19 individuals (Laber \& Ranner, 1997). In 1992 and 1993, a pair was still nesting at Lake Zell (Salzburg), but in 2006 the taxon was absent (Sotta-Bachmayr et al., 1993; Robl, 2007). Up to 1999, only four nesting pairs were reported in Carinthia (Raß et al., 1999). In May 1999, an individual was observed in Aholfing (Bavaria) (Fünfstück, 1999). On 15 May, 2010, one appeared in Ehingen (Baden-Württemberg) (Weiß, 2012). In Germany, the subspecies was reported 


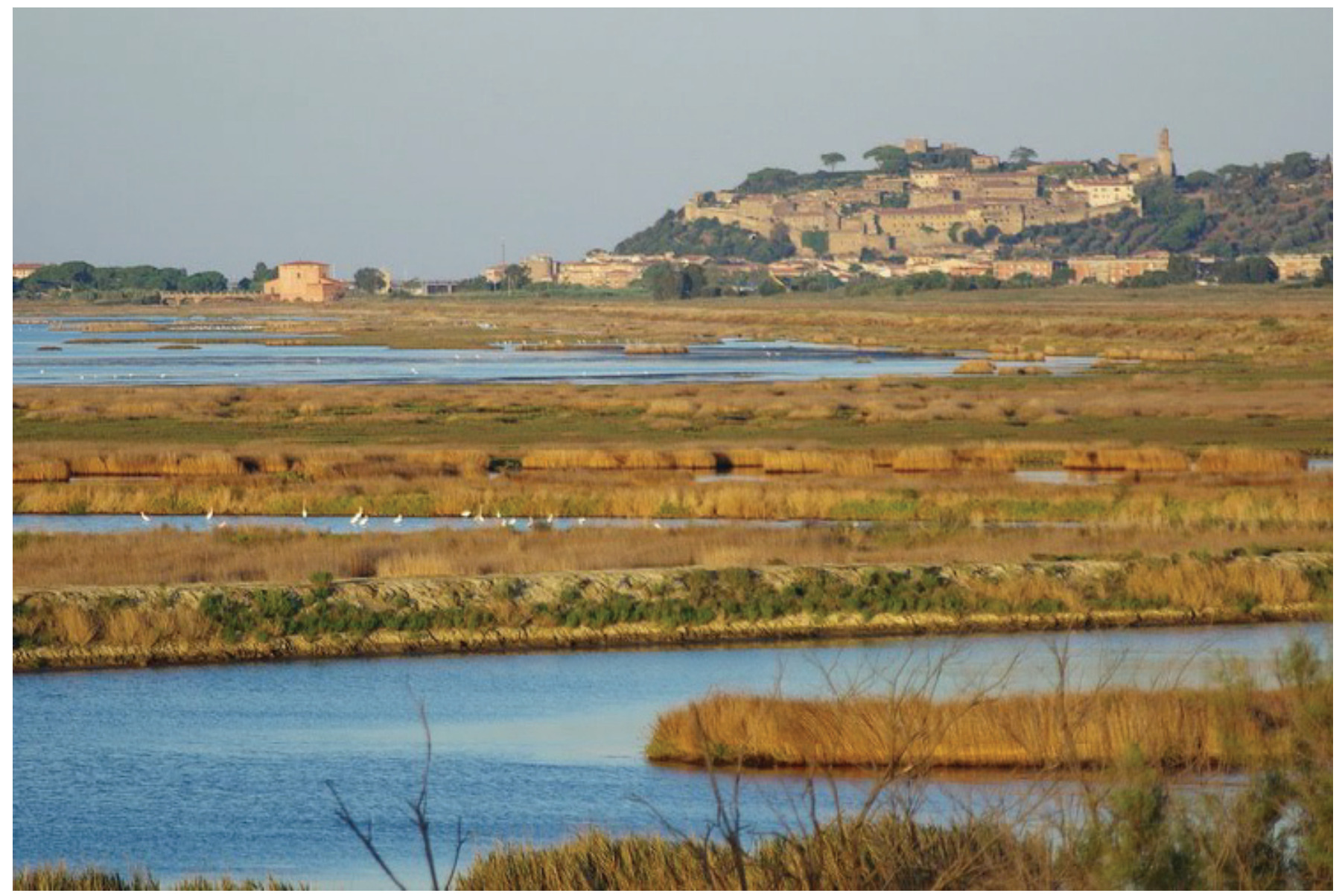

Fig. 9 - The Diaccia Botrona Marsh (photograph: Beppe Miceli)

irregularly from 1980 to 2005, with an average of less than five observations per year (Barthel \& Helbig, 2005); between 2003 and 2015, it was reported at least 19 times during the spring migration period (April-May) (Club300 Deutschland, 2015), but without any nests observed in the period 2005-2009 (Sudfeldt et al., 2013). In Bavaria from January 1, 1980, to January 31, 2012, there was a total of less than ten reports (Otus, 2012). In 2000-2001, the Black-headed Yellow Wagtail was nesting at at least four sites in Upper Austria (Uhl, 2003), and from 2004 to 2006 in the Rhine Delta (Vorarlberg) (Albegger, 2009). In 2006, it was breeding in the Tyrol at Thaur (Gstader, 2006), and in 2013 a nesting male was seen again in Carinthia (Probst \& Bartas, 2013).

The subspecies was observed for the first time in the Canton of Valais (Switzerland) on 30 April, 1986 (Desfayes, 1986). In 2011, a male feldegg paired with an unidentified female was reported raising two chicks in Sant'Antonino (Ticino) (Marques et al., 2013). In the period from 1992 to 2009, there were 49 reported sightings in Switzerland, totalling 55 birds; the reports increased to 69 the following year, for a total of 76 birds (Wassmer \& Haag, 2011). In 2011, the total number of reports for the the Swiss Confederation was 73, for a total of 80 birds (Piot \& Vallotton, 2012); in 2012, the total number of reports rose to 82, for a total of 91 birds (Marques et al., 2013).
In France, a male was observed in the Loiret Department (Centre-Val de Loire) in summer 1982 (Chesneau, 1983). Two individuals were observed in Haute-Savoie (Géroudet, 1985). Overall from 1984 to 1987, five sightings were recorded in the Isère Department (Rhône-Alpes) (Deliry, 1986; LPO Isere, 2015). After several sightings in the Camargue in the 1980s (Blondel \& Isenmann, 1981; Boutin \& Cherain, 1989), the subspecies was supposed nesting there in 1992 due to repeated reports of a male in the breeding season (Thibault et al., 1997); from 2003 to 2006, the bird appeared regularly in the spring (GauthierClerc et al., 2008). On 12 June, 2007, a male paired with a cinereocapilla female was seen feeding chicks in the salt marshes of Hyeres-les-Palmiers (Provence-Alpes-Côte d'Azur) (Issa, 2008). In 2011, a male was observed from 9 April to 10 July in the Hautes-Alpes Region, but without evidence of breeding (Reeber \& the CHN, 2012).

In Slovakia in 1988, an unfledged chick was ringed near Lake Orava (Žilinský kraj) at an altitude of about $600 \mathrm{~m}$ a.s.l. At the same location, mixed feldegg and flava pairs were reported (Karaska, 1988; Sabo et al., 2010). Further nesting was recorded in 1994 (Vongrej \& Darolova, 1994). However, the birds' appearance in Slovakia remained very rare. In the swamps at Beter (Lučenec, central Slovakia) in the period 1991-2008, the subspecies was observed once, on 13 April, 2000 (Karaska, 2005; Kerestúr \& Mojžiš, 2008). Reports are still under evalu- 
ation by the Slovak Rarities Committee: the report of an adult male observed in Malé Leváre (Bratislava) on 19 April, 2013, was recently approved (Kvetko \& FK SOS/ BirdLife Slovensko, 2014).

In the Czech Republic, the Black-headed Yellow Wagtail appeared six times in the period 1989-2000, and from 2001 to 2012 it was reported another six times (Chytil, 1995; Vavř́k, 2002; Vavřík \& FK CSO, 2011; 2012; 2013).

In Poland, it was observed in 1981 and 1982 (Tomiałojć, 1990), and on 26 April, 2003, a male was reported in western Pomerania for the first time (Kajzer et al., 2005); in 2008, there were 63 reports on a total of 103 individuals (Faunistyczna, 2009), and two years later the reports totaled 67 for 107 individuals (Faunistyczna, 2011). However, a 2014 review of the data for the period 1981-2011, validated only 25 reports on a total of 33 birds (Faunistyczna, 2014).

In Latvia, only four reports were made: one in May 1982, one in May/June 2000 and two separate ones in 2011 (April and May) (Celminsš et al., 1993 and unpublished material from Latvijas Ornitofaunistikas Komisija). A male feldegg was observed in Liepaja from May 22 to June 4, 2000, and there was verification of a breeding pair (nest with six eggs) with a female of uncertain attribution (Ornitofaunistika, 2015). The subspecies appeared sporadicaally also in Estonia (four reports up to 2002, the last two in 1989 and 1998) (Ots \& Lilleleht, 2002). It was also observed in Lithuania: a male was seen on 1 May, 2012, in the Nemuras Delta (Jusys, 2012).

In Finland from 1960 to 2012, there were 14 reports distributed as follows: three in April, ten in May and one in July (BirdLife Finland, 2015), for a total of 20 individuals (Lehikoinen et al., 2013). In Sweden, of 45 reports presented up to 2008 , a comprehensive review validated only nine (two of which related to the same individual), the first of which was dated May 1983 (Hellström, 2009). In Denmark, a similar review led to the exclusion of 13 of the 14 previously accepted sightings (Kristensen et al., 2010): the only valid observation was one dated July 2006. To this, a new sighting in May 2012 has been added (Neergaard, 2013).

In Belgium, the species was observed for the first time in 1992, in Frasnes-lez-Anvaing (Wallonia): a male was seen paired with a female of uncertain subspecies from 11 June to 28 July and was bringing up two fledglings (Verroken \& Verroken, 1995). A second sighting in May 1997 (De Smet et al., 1998) was invalidated by a review of the data (Selosse et al., 2002). Up to 2005, a total of three sightings were validated (De Smet et al., 2006).

An individual was reported for the first time in Luxembourg on 1 May, 2001. Two other individuals were observed on 30 April, 2002 (Lorgé et al., 2004). However, a subsequent review considered valid only the first sighting. A male was reported in Redangeon on 18 May, 2013 (Lorgé et al., 2014).

For the Netherlands, all 25 reports collected from 1980 to 2015 have been rejected (Ovaa et al., 2008; Dutch Avifauna, 2015). Similarly, other reports made on May 1960 have not been accepted (Kist \& Waldeck, 1961; Klatte et al., 1962).
In Britain, there were 17 reports of the taxon up to 1988 , but a 2006 review of the data validated only nine (Kehoe C. \& BBRC, 2006); the number rose to 13 in 2009 (Hudson \& the Rarities Committee, 2010). For Wales, four isolated observations were reported up to 2013 , always occurring in May, in 1986, 1998, 2011 and 2013 (Green, 2014). The subspecies was reported for the first time in Ireland in Londonderry on 24 April, 2007 (Milne $\&$ McAdams, 2008); up to the end of 2013, no other sightings were made.

In Moldova, the bird was observed nesting in the Dniester Delta, near Nezavertailovca on the border between Transnistria and the Ukraine (Filipenko \& Tishchenkov, 2013).

In the Ukraine, the Black-headed Yellow Wagtail was not abundant (1000-2000 pairs in total) (Gavris', 2003), but was a regular nester especially along the coast (Fesenko \& Bokotej, 2007; Moskalenko, 2015). It was breeding in the Chernivtsi Oblast in 1976, and in 1995 the presence of at least two pairs was confirmed (Buchko et al., 1996). In 2013, there were pairs reported near Chervonopillya (Kirovograd) in the breeding season (Grishchenko \& Yablonovska-Grishchenko, 2014). It was present in the Tiligul Valley (Odessa), in the Yuzhny Bug Valley (Mycolayv) and in the salt marshes at Chervonyi (Kherson) (Stepanian, 1990; Dudkin, 2004); it was likely nesting in Bukovina and Transcarpathia (Grishchenko, 2004; Dudkin, 2004), and certainly nesting in the Luhansk Oblast (Yevtushenko \& Litvinenko, 2010). Two pairs were established to be nesting at Balabino (Zaporozhskaya) in 2008 (Kostiushyn et al., 2014). Until the early 1980 s, nests were present on the Crimean plain (Kostin, 1983), and in the next decade it was also reported on the highlands near Sevastopol, subsequently reaching the western and southern coasts of the peninsula (Beskaravayny, 2007; Belogorsky Eco-center, 2013). The bird was nesting near Lake Barakol (Beskaravayny, 2001), but was present along the northeastern coast of the peninsula only during the migration period (Siokhin et al., 2000).

The subspecies was reported nesting in the oblasts of Rostov (Sidenko, 2003) and Stavropol (Harin, 2014), in the Zaporozhia Oblast (Matruhan, 2010; 2013) and in the Taman Peninsula (Krasnodar territory) (Belik et al., 2009). In the area around Narimanov (Astrakhan), feldegg was less common than flava and, especially, lutea (Arkhipov et al., 2003; Pavlova et al., 2003). Further south, along the coast of the Caspian Sea, it was present in the delta of the River Terek (Dzhanmirzoev et al., 2010). In the district of Mozdok (North Ossetia-Alania), it was nesting at a density of 14.6-32.5 pairs $/ \mathrm{km}^{2}$ (Komarov et al., 2011), and was also nesting in the Adygea Republic (Perevozov, 2012), in the steppes of Kalmykia (0.7-1.8 pairs $/ \mathrm{km}^{2}$ ) (Durnev et al., 2013; 2014; Chestin, 2014) and in the Penza Oblast (Molodovsky, 1997). In June 1982, a pair displaying breeding behaviour was observed for the first time in the Middle Volga Region at Naberezhnye Chelny (Republic of Tatarstan); other birds were observed near Kazan (Molodovsky, 1997; Askeyev \& Askeyev, 1999; Muraviev, 2010). Molodovsky (1997) also cites Ufa (Bashkortostan) as a breeding area, but there were no subsequent confirmations nor was this data cited by Arte- 
myeva \& Muraviev (2014). In June 1975, the subspecies was found breeding at Ulyanovsk, albeit sporadically: indeed, sighting of males in the region in spring 2000 was considered exceptional (Borodin, 2002; 2006; Borodin et al., 2007; Muraviev, 2010). Reports of possible nesting sites in Saratov Oblast were not validated (Muraviev, 2010). Breeding of the subspecies was again confirmed in Orenburg Oblast (Molodovsky, 1997; Ryabitsev, 2001). Updated summaries of the breeding range in the Ukraine and southern Russia are given by Flint et al. (2000) and Artemyeva \& Muraviev (2014).

\section{Middle East}

In Turkey, the Black-headed Yellow Wagtail was breeding in a wetland area of the Alpu Plateau (central Anatolia) at about $760 \mathrm{~m}$ a.s.l. (Erdoğdu, 2001). It was abundant (about 2,500 pairs) in the delta of the River Kizilirmak (Black Sea) (Wetlands International, 2003) and was also nesting in the wetlands at Sakaryabaşi/Eminekin (Aslan \& Kiziroğlu, 2003). It was present also at Lake Ercek (Adizel \& Durmuş, 2009). In the breeding season, it could be found at the Göksu Delta (Mediterranean Sea), in eastern Anatolia (especially in Van Province) and near Lake Tödürge (central Anatolia) (Simpson \& Ketchen, 2008). A summary of the breeding area in Turkey is provided by Kirvan et al. (2008).

In Georgia, it was nesting in Udabno (Kakheti) (Dubois, 2007), was common in the breeding season at Ninotsminda (Samtskhe-Javakheti) (Kon-Tiki Tours, 2012), and could be found on the Javakheti Plateau (SamtskheJavakheti) (Hafner et al., 2007) and at Imereti (Sakata et al., 2008).

In Armenia, it was reported in Yeghegnadzor (Vayots Dzor), in Armash (Ararat), in Hrazdan (Kotayk), at Lake Sevan (Gegharkunik) at $1900 \mathrm{~m}$ a.s.l. (Ananian, 2001; Batty, 2004; Hansson \& Bergström, 2013; Orbie, 2013) and in Shirak Province (Tailly, 2001; Anselin \& Tailly, 2006).

In Azerbaijan, it was nesting on the Lenkoran Plateau (Heiss, 2010; Gauger \& Heiss, 2011), at the oil terminal at Sanqaçal (Baku) (Aspinall et al., 2001) and in Agh Gol Natural Park (Beylagan) (Green \& Soylu, 2014).

Its presence on Cyprus was very rare: it was reported breeding in the marshes at Sotira, in the south-east (Richardson, 2012), and near the salty lake at Akrotiri (BirdLife Cyprus, 2001), the wetlands near Lake Oroklini and the valley of the River Xeros (Hellicar et al., 2014).

In Lebanon, the Black-headed Yellow Wagtail was relatively common as a nesting bird in the period 19951996 (Serhal \& Khatib, 2014), especially along streams in Bscharri District, at about 1,500 m a.s.l.; in 1996, a flava $\mathrm{x}$ feldegg pair was nesting in Ehden (Zgharta District), again in a mountainous area $(1,500 \mathrm{~m}$ a.s.1.) (RamadanJaradi \& Ramadan-Jaradi, 1997); it was also present along the River Litani (Leontes) in the Beqaa Valley and in the vast wetlands of Ammiq (Ramadan-Jaradi \& RamadanJaradi, 1999; Ramadan-Jaradi et al., 2008). Its presence was further consolidated in 2000, making it a common nesting bird there (ECODIT, 2015).

In Israel, it was nesting regularly only in the Hula Valley, where up to 15 pairs were recorded in the early 1980s; however, its numbers later declined (Mayrose \& Alon, 2002; Perlman \& Meyrav, 2009). A pair bred successfully in Be'er-Sheva in 1983 (Shirihai, 1996), and in 2003 another pair was recorded in Neot HaKikar, south of the Dead Sea (Balmer \& Betton, 2003).

In 1994, it was present during the breeding season in Azraq, a wetland area of Jordan (Hofland, 1994), a country in which it bred locally (Bertilsson, 2004).

In Syria, it was common in Mheimideh (Deir ez-Zor) on the Euphrates (Hofland, 1994; Dubois, 2006; Kehoe, 2010), where it was ascertained nesting in May 2008 (Murdoch, 2007; Murdoch \& Betton, 2008). Along the same river, it was common at Jazara as well as in the wetlands of al-Sabkhat Jabbul (Aleppo) and in Bahrat Homs (Homs) (Murdoch, 2003; Dubois, 2006).

The Black-headed Yellow Wagtail was probably nesting in Iraq (Salim et al., 2009; Porter et al., 2010; Ararat et al., 2011), especially in the second half of the 1990s, in the Al-Auda Marshes (Maysan Province) (Al-Thahaibawi, 1999); however, it was not encountered in the large marshes north of Basra in 2004 and 2005 (Abed, 2007).

In Iran, it was very common as a nesting bird in the wetlands at Meyghan (Markazi Province) (Tohidifar et al., 2009). According to Porter \& Aspinall (2010), the birds' distribution in this country was very large, extending from the north-west to the south and to the east along the Black Sea coast, and down to the south in eastern Iran.

In the summers from 1998 to 2001, the Black-headed Yellow Wagtail was present in an agricultural area located about $80 \mathrm{~km}$ south-east of Riyadh (Saudi Arabia), and in 2001 it was established nesting there (Bertilsson, 2004; Jennings, 2010). From 4 to 18 July, 2014, two males and a female were observed in the Sabkhat Al Fasl Lagoons, but there was no evidence of breeding (Babbington, 2014).

In the United Arab Emirates, after uncertain reports of nesting at a wetland area in Abu Dhabi in 2003 (Aspinall \& Hellyer, 2003; Pedersen, 2008) and in 2010 (Smiles et $a l ., 2012$ ), it was ascertained breeding in irrigated meadows $18 \mathrm{~km}$ east of Dubai in June 2011 (Pedersen \& Aspinall, 2014). This was confirmed in 2013 (United Arab Emirate Forum, 2013).

In Kuwait, it was considered only a migratory and wintering species (Pope \& Zogaris, 2012; Al-Sirhan, 2015).

\section{Central Asia}

In Kazakhstan, the Black-headed Yellow Wagtail was reported nested along the coast of the Caspian Sea between the Volga and the Ural (Brandt, 2005), in Zhanaqala (Volga-Urals) (Lachmann, 2010), near Lake Batpakkol (between the River Emba and the Mugodzhary mountain range), in Kurgaldzino Nature Reserve (Tengiz-Korgalzhyn District, Aqmola) (Andersen, 2003; Gavrilov \& Gavrilov, 2005), in Makat District (Karpov, 2009), along the coast of the Mańğystau Region, including the urban area of Aktau (Le Nevé et al., 2010), in Kysylsai State Regional Nature Park (Mańğystau) (MOTC, 2012), in the upper valley of the Emba (Krivizkiy et al., 1985), along the lower course of the Irgiz and Turgai, near Zhezkazgan in the valley of the River Syr Darya (Fig. 10) to the Aral Sea Delta (Ryabtsev, 2014) and along the coast of the Small Aral (Stiftung, 2013), in Betpak-Dala District (Fun- 


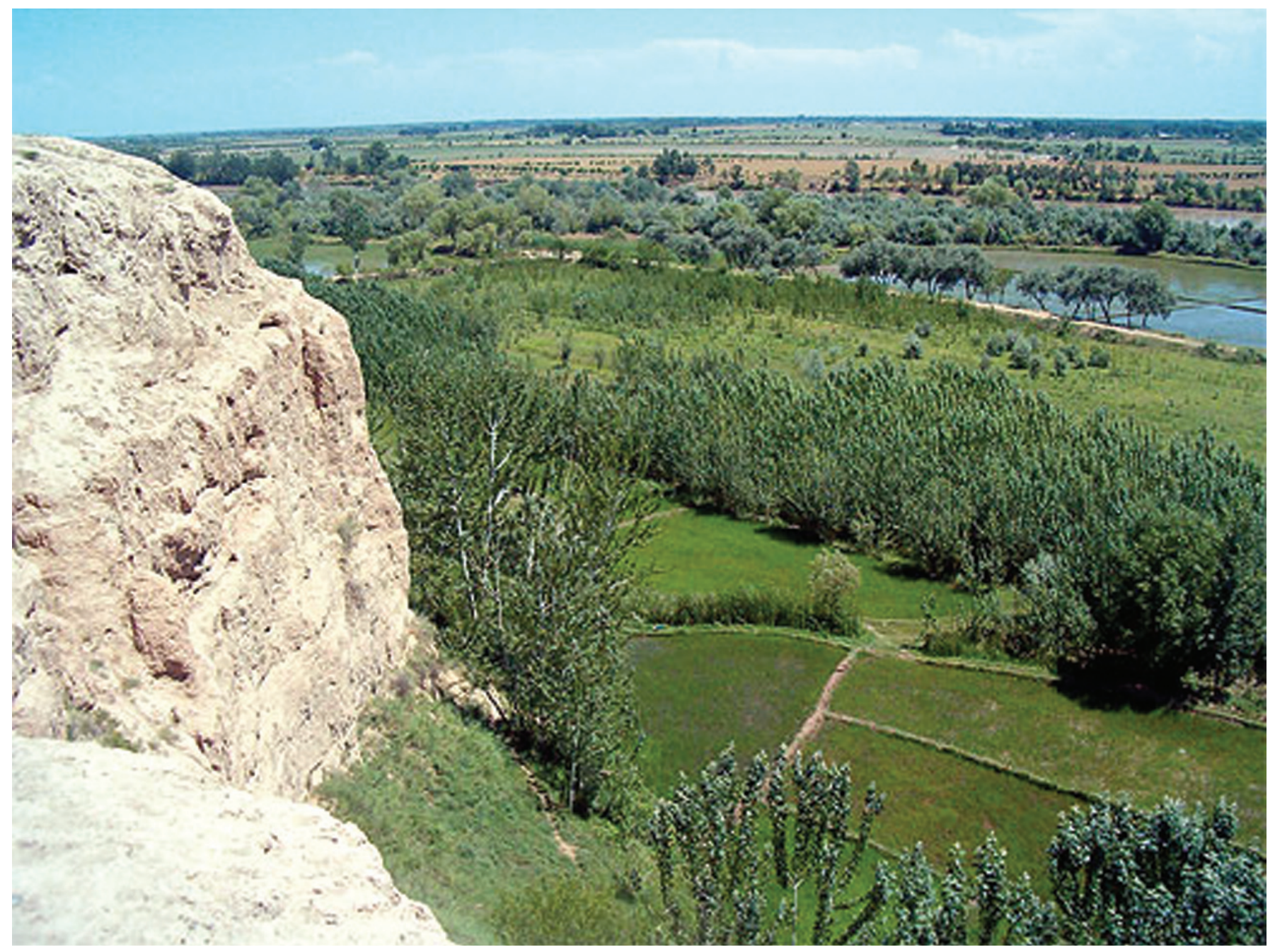

Fig. 10 - Irrigated croplands in the basin of the River Syr Darya (source: http://www.orexca.com).

dukchiev, 1987) and in the Steppe of Hunger (Chardara, Keles, Shieli) (Otarov \& Ibrayeva, 2002). It was present in Almaty, near Lake Sorbulak, in Charyn (Almaty), at the delta of the Ili (especially in wetlands close to Topar), and between Quapshaghay and Baqanas, near Aqzhar (River Ili) and Qyaraoy (Taukum Desert) (Taylor, 1999; van den Schoor, 2003; Pavlova et al., 2003; Andersen, 2003; 2004; 2006; 2009; Kennerley \& Kovshar, 2005; Blomdahl, 2006; De Coster et al., 2008; van der Dol \& Valkenburg, 2009; Dortu, 2011; Hennlein, 2015). It was present during the breeding season at Chokpak (Kehoe, 2005) and in the Ili-Alatau National Park (Karasay) (Roberts \& Bishop, 2009). It was reported as a regular breeding bird in the Lake Alakol Natural Reserve, especially at the delta of the River Tenket and islands of the lake (Berezovukov, 2006). It was also present along the River Irtysh in Ust-Kamenogorsk (Gavrilov \& Gavrilov, 2005) and in the Zaysan depression of the River Kaldzir (eastern Kazakhstan) (Green \& Kolbintsev, 2001; Gavrilov \& Gavrilov, 2005; Starikov, 2008; Kovshar, 2012). In the latter area, feldegg was less common than the beema subspecies (Cardy \& Kolbintsev, 2002) and had not been observed in the period 1962-67 (Survillo, 1971).
In Uzbekistan, the Black-headed Yellow Wagtail was reoported at the lakes at Tukul and Tuzkan (Birch, 2010; Blomdahl, 2014). In the latter location, it was not observed during research conducted in 1983, 1987, 1990 and 1995; breeding was reported in 1998 and confirmed in 2006 (Filatova, 2012). It bred in irrigated areas along the Amu Darya and in the islands of the delta (Joger et al., 2012), as well as at Lake Dengizkul (LUKOIL Uzbekistan Operating Company LLC, 2013). In the breeding season, it was reported at Bukhara (Anderson, 2007; Roberts \& Bishop, 2009; van Beirs, 2013), in Kogon (Bukhara), Qorovulbozor (Bukhara) and Kitab (Kashkadarya) (Lastukhin, 2014). It was a common breeding bird in the Kattakurgan Reserve (Samarkand) and at the lacustrine system of Aydar-Arnasay (Kyzyl Kum); it was rather uncommon in the Nuratau-Kyzyl Kum area (between Samarkand and the southern part of Lake Aydar) (BirdLife International, 2015b).

In Kyrgyzstan, the subspecies nested at Lake Issyk Kul, in the Chuy Valley, in the provinces of Naryn and Talas, in the western part of the country and, in general, was widespread in open areas and grasslands throughout the country (Shukurov, 1991; Andersen, 2004; Toropova \& Kulagin, 2006; Holmstedt, 2012; Romanov \& Berezovikov, 2015). 
In Turkmenistan, it was observed during the breeding season in wetlands at Aşgabat (Ahal) and Repetek (Lebap) (Pettersson, 2012), while it was only migratory in the south-west of the country (Olschewski, 2011). In Tajikistan, it was reported nesting in the valley of the River Beshkent and near Shaartuz (Kvartalnov, 2011; 2014).

In Afghanistan, the subspecies was present near Delaram (Nimruz) along the River Khash from 12 June to 11 September, 2011 (Rouse, 2011).

In China, melanogrisea was reported nesting in the Tien Shan and Tarbagatai mountain ranges of Xinjiang (MacKinnon \& Phillipps, 2000; Ming, 2011; China Animal Scientific Database, 2013). Especially in Kazakh Autonomous Prefecture, a male was present in June 1998 along the River Ili at Xinyuan (Kilburn, 1998), while in May 2011 breeding pairs were observed at Lake Ebinur (Hellquist, 2011); they were also reported at Kuytun, Shawan, Shihezi, Changji and Mu Lei Ren Jia (Ming, 2011). These are the extreme eastern points of the breeding range of the subspecies: indeed, the bird has not been detected in adjacent areas just to the east, such as the basin of the River Tarim, Lake Bosten, the Turpan Depression and Urumqi (Beaman, 2013).

In the northeast, the subspecies occasionally reached Krasnoyarsk, the region of Irkutsk and Lake Baikal (Fefelov, 2001; Koblik et al., 2006; Arlott \& Khrabry̌r, 2009; Dorzhiev, 2011; Artemyeva \& Muraviev, 2013; Melnikov \& Gagina-Scalon, 2014; Melnikov, 2015).

On 13 May, 2013, a Black-headed Yellow Wagtail was observed in Beijing at Lake Shahe: this was probably the first report in China outside the borders of Xinjiang (Townshend, 2013), and is the easternmost sighting known for the taxon.

The breeding range of feldegg known for the period 1981 to 2015 is shown in Fig. 11.

\section{DISCUSSION}

The sequence of maps given here on the distribution of Motacilla flava feldegg demonstrates not only the progressive increase in information available on the taxon over time, but also the evident changes occurring in its

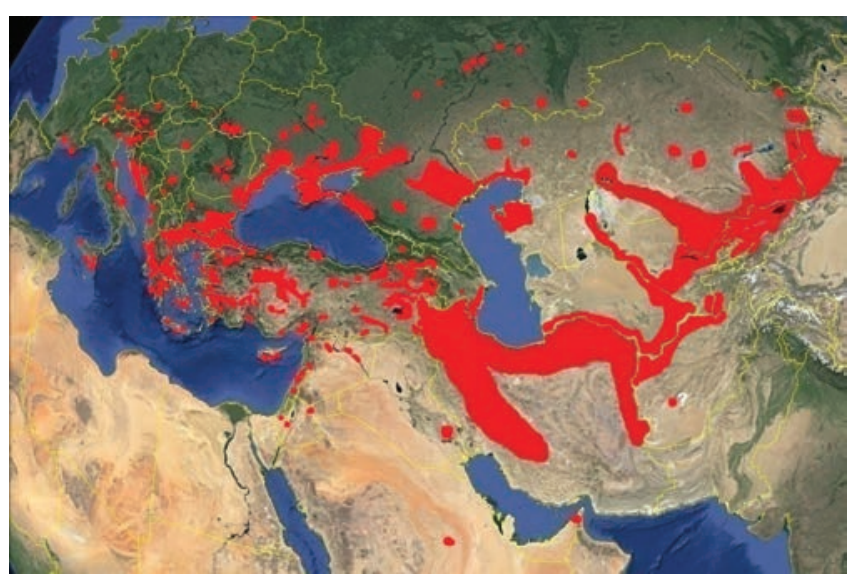

Fig. 11 - In red, the 1981-2015 breeding range of Motacilla flava feldegg. The white question mark indicates a doubtful site. breeding range. In assessing the causal environmental factors of these changes, whether biotic or abiotic, it should be taken into account that the distribution of a species is influenced by a hierarchy of factors, with temperature at the apex, followed by rainfall/humidity and, finally, by local environmental factors (Grinnell, 1914; Root, 1988; Gaston, 2003; Pigot et al., 2010). With regard to climatic factors, the effects intensify as the range of a species increases (Pigot et al., 2010); this is precisely the case for the Black-headed Yellow Wagtail. As for local environmental factors, of particular importance is land use - and any changes it has undergone, such as variations in the type of crop grown and in the agricultural practices used - on account of the effect it has on the birds' distribution and population density, eating habits, reproductive success and survival rates (Schifferli, 2001; Guerrero et al., 2012).

Based on these premises, the aim here was to analyse the changes that have occurred to the subspecies' breeding range, dividing it into a number of macro areas that take into account the broad biogeographical diversity inherent in such a vast territory.

\section{The Balkans and west Europe}

The evolution of the breeding range of feldegg over the period studied can be summarized as follows:

- The northern margin of the breeding range remains stable up to the early 1950 s, with reproductive territories ideally limited geographically by a line linking the Adriatic coast to the Black Sea, starting from Lake Skadar (19th meridian east) and reaching the Bay of Varna (Bulgaria), passing through Kosovo and southern Serbia between the 42th and 43th parallel north. Breeding occurs only occasionally in more northern regions. As reported by Munteanu (2006), the only exception is the Danube Delta, which for decades was a sort of "feldegg island" within the range of the flava subspecies.

- Within the southern portion of the Balkans thus delimitated, there is progressive occupancy of new territories in Macedonia and southern Serbia. In the past, various authors have examined the changes occurring in the distribution of the feldegg subspecies in the Balkans during the first half of the $1900 \mathrm{~s}$, but they have given different interpretations to the data. Stresemann (1920) considered the northern limit as a line passing ideally across the northern portion of Lake Skadar, central Serbia at the height of the town of Ćićevac, and Bulgaria to the Danube. According to Hartert (1922), the limit was more to the south, going from Lake Skadar to Bulgaria via Niš (central Serbia). Maštrović (1942) believed that there had been no substantial changes compared with the 1920s, with the more northern nestings being only sporadic cases. Instead, Makatsch thought that northern Macedonia formed this limit - in other words, that it was further south than indicated by the previous authors. A few years later, he reported that in the 35 years from 1920 to 1955, the limit had moved only from a line going from the West Morava to the Danube to one from the Danube to the Sava (Smederevska Palanka, central Serbia) (Makatsch, 1950). According to Patev 
(1950), the limit still coincided with that described by Stresemann in 1920. Finally, Cãtuneanu et al. (1962) considered the range limited to Greece and Bulgaria up to 1895 , then expanding northwards until, in 1922, it reached the limit described by Stresemann, with a further modest northwards expansion up to 1955. As previously described, all these developments took place within a geographical area that had been delineated already at the end of the 1800s, as shown in Fig. 6.

- The taxon reaches an important juncture in 1953 when breeding starts on the island of Krk (Kvarner Bay, Croatia): indeed, within the next decade the bird reaches Istria, is reported in several areas in Romania, and starts breeding along the Italian Adriatic coast (in Romagna and Apulia), defining a northern border running from Istria to the Black Sea, between the 45th and the 44th parallel north, and moving westwards to the 13th meridian east.

- In 1967, with nesting sites appearing in the Canton of Ticino (Switzerland), breeding begins in the Alps, especially in Austria. The first reports in Hungary and along the Italian Tyrrhenian coast also occur. Thus, by 1984 a new northern limit is defined, going from Lake Constance, through Austria and Hungary, and reaching the Ukrainian Oblast of Chernivtsi, along the 47-48th parallel north, with a simultaneous shift of the western limit between the 10th and 9th meridian east.

- Between 1980 and the end of the 20th century, some breeding sites are reported in areas beyond the boundaries outlined previously (including Montereau-FaultYonne in France, Lake Orava in Slovakia, Frasnes-lezAnvaing in Belgium, Liepāja in Latvia, and a possible nesting site in Camargue, France). However, they are isolated cases, mostly of mixed pairs and without any impact in following years.

- At the beginning of the 21 st century, the expansion of the birds' range towards the north seems to lose momentum, while it becomes consolidated westwards, with repeated breeding in Italy (on the mainland and in Sicily); there is also an isolated nesting reported in France (at Hyères-les-Palmiers).

Between 1952 (the year before breeding on Krk) and 1984 (when there is breeding in Baden-Württemberg), the northern limit shifts northwards about $555 \mathrm{~km}$, i.e., 17.3 $\mathrm{km} /$ year. The magnitude of this figure is comparable with the speed of northwards advance of the summer isotherms in eastern Europe between 1951 and 2010 (i.e., 10.4-15 $\mathrm{km} /$ year) (Beniston, 2013).

In conjunction with these changes of the breeding range, the taxon's migration pattern is also altered. In fact, until the early $1960 \mathrm{~s}$, feldegg appears only rarely in some countries of west Europe (there are doubts about some of the sightings, given the possible confusion with thunbergi). Only in the south of Italy, and along its Tyrrhenian and Adriatic coasts, is the presence of the bird relatively regular. Later, especially in the 1980 s, the presence of the subspecies becomes more frequent and regular on the European continent, as demonstrated by the following data:

- In France, an average of 2 individuals/year are reported between 1981 and 1990; from 1991 to 2000, there is a decrease to 1.1 individuals/year; and between 2001 and 2010, sightings reach 6.5 individuals/year (Reeber et al., 2008; Reeber \& le CHN, 2012; CHN, 2015);

- In Switzerland, an average of 3.06 individuals/year are reported between 1992 and 2009 (Wassmer \& Haag, 2011), rising to 12 individuals/year in the 2010-2012 period (Piot \& Vallotton, 2012; Marques et al., 2013);

- In 2008, the Birds Rarities Committee of Austria stops considering reports of the taxon, on account of the regularity with which it is being sighted (Ranner \& Khil, 2011).

- As well as in terms of frequency, migration in Europe also assumes a greater magnitude towards the west and the north. In fact:

- The presence of feldegg in the Iberian peninsula is confirmed for the first time by a sighting in Castro Marim (Algarve, Portugal) on 4 April, 1987 (de Juana \& Comité Ibérico de Rarezas de la SEO, 1989; 1990); the bird is observed for the first time in Spain on 4 May, 1989, in Barcelona (de Juana \& Comité Ibérico de Rarezas de la SEO, 1993). Eight sightings are validated in Spain between 1989 and 2008, for a total of 9 individuals (0.45 individuals/year) (Dies et al., 2008); the same number of sightings take place between 2011 and 2013 (3 individuals/year) (de Juana \& Garcia, 2015), especially in Catalonia. In actual fact, the subspecies may have been far more numerous in the latter region: indeed, in Emporda Region alone, there are 16 sightings reported between 1998 and 2011, for a total of 17 birds (only one was validated; the non-validated sightings were probably due to incomplete documentation) (Alvarez-Cros, 2012).

- Sightings are reported in Ireland in April 2007 (Milne \& McAdams, 2008) and in Norway in June 2008 (two previous sightings were not considered valid) (Olsen et al., 2010).

As already highlighted in the 1960s (Cãtuneanu et al., 1962), the spring migration routes from African wintering areas to Europe are substantially three. The first sees the passage of the Black-headed Yellow Wagtail from Tunisia and Malta to the Sicilian coast, continuing mostly along the Ionian and Adriatic coasts of the Italian peninsula (a subordinate route exists along the Tyrrhenian coast) and then heading towards the Balkans. The second reaches Greece, starting from Libya and passing by Crete and the Cyclades (Nisbet, 1967). The third passes through Egypt, Palestine and Syria, thereafter going due north or eastwards, primarily to Iran. From the late 1980s, a fourth, more western, migratory route seems to emerge for the transit of small flows through the Strait of Gibraltar. This is suggested by the appearance of the Black-headed Yellow Wagtail in Morocco and Spain during the spring migration. Up to 2014, there are only 5 known sightings in Morocco (the last was in 2005), all of which occurred between late March and April in the south-eastern part of the country (Bergier et al., 2006). The birds probably arrived from Mauritania, where the taxon is present in small numbers from October to March/April (Lamarche, 1988). Males were reported also on the Canaries: one was sighted on Lanzarote on 17 April, 1999 (Clarke et al., 2006); three on Fuerteventura, between 4 and 10 May, 2008 (separate sightings in mixed flocks of flava and thunbergi); another on Lanzarote between 5 and 
9 May, 2008 (Lorenzo, 2008); a "superciliaris" from 19 to 21 March, 2010 (Sagardia \& GarcíaVargas, 2010); and one, perhaps belonging to the subspecies, on La Graciosa, photographed on 20 May, 2015 (Portales, 2015). Although the first three observations were not validated by the Spanish committee, they are still cited by ornithologists specifically studying the birds of these islands (Ramos Melo \& González Del Campo, 2014). For Spain, the data shows a progressive intensification between late March and early May in the sighting of individuals going north-east along the Mediterranean coast to reach their breeding areas from the west. This small stream converges towards the French Mediterranean region to join other parties coming from Corsica, where the wagtails are observed with increasing frequency (24 sighting between 1980 and 2011, mostly in the last ten days of April and almost all concentrated in the extreme northern tip of the island), probably coming from the Italian Tyrrhenian coast (Arcamone \& Puglisi, 2006; Sacchi et al., 2010; Giovacchini \& Stefanini, 2015). Once the wagtails reach southern France from the south (Corsica) or the west (Spain), they fly north along the Rhône Valley, with some probably reaching Switzerland along the river's course, while others continue north along the Saône Basin. The number of birds observed in the Rhône-Alpes and Franche-Comté regions, as well as those present even further north, reaches a peak in the first ten days of May. Similarly to the route passing through Gibraltar, also the spring migration route that passes through Corsica seems to have become significant only in the last two decades of the 20th century as a possible optimization route to reach the new breeding sites in Europe. It is conceivable that the western route may become important in the future also for post-breeding migration, in that individuals attributable to the hybrids flava $\mathrm{x}$ feldegg and feldegg $\mathrm{x}$ cinereocapilla were captured already during the 1992-1995 ringing campaign conducted at the mouth of the River Ebro in Catalonia (Aymì, 1999).

Regarding the factors that may have led, or contributed, to the changes described above, a number of considerations can be made with respect to the different historical periods.

The first expansion - taking place in the south Balkans up to the $1950 \mathrm{~s}$ - does not seem to have been caused by any significant environmental or climatic changes, and, given its relatively limited geographical extension, may be part of a physiological increase in local population that caused territorial expansion without any actual change in the breeding range's northern border.

After World War II, widespread collectivization of agriculture in the late 1950s and early 1960s in most of the Balkans produced an intensification and mechanization of agricultural activities, eliminating the pure subsistence farming techniques in place up to then (Jeffries, 1996). But, except for a slight decline in the cultivation of cereals, this did not result in any substantial changes in agricultural production and, consequently, in land use (Enyedi, 1967; Allcock, 2000). However, towards the end of the 1900 s, a progressive desertion of small farms (especially in the mountains) and the concentration of the population in urban areas caused a decline in cultivated land area and a gradual, spontaneous re-naturalization of the terrain left untended. The conflicts that developed in the 1990s in the former Yugoslavia contributed to the partial abandonment of the countryside. In 2000, agricultural land occupied about $45 \%$ of the surface area of the Balkans, with forests occupying about 40\% (European Environments Agency, 2010). These elements, together with the finding that the main routes of the subspecies' expansion in the Balkans coincides with waterways, such as the Little Bačka Canal (Keve, 1961), suggest that nether biotic factors nor the changes in land use in west Europe can justify the strong northerly progression of the wagtail. In actual fact, the intensification of farming may have played an exactly contrary role, even if one mitigated by the fact that the breeding sites of feldegg in west Europe almost always coincide with areas of natural or semi-natural wetlands.

With respect to possible abiotic factors, temperature fluctuated in the Balkans during the 20th century: after an initial cold period, the temperature became higher in the second two decades, before falling back in the 1940s; from 1950 to 1970 , values were above average, but then there was another decline up to the 1980s; since then, temperatures have been rising (Radeva \& Alexandrov, 2009). In the period 1950-2006, there was an overall warming of the area, which was gradually more pronounced progressing south to north (from 0.005 to $0.01^{\circ} \mathrm{C} /$ year in Greece, Albania, Macedonia and Bulgaria; from 0.015 to $0.02^{\circ} \mathrm{C}$ /year in Montenegro, Serbia and Herzegovina; and from 0.025 to $0.03^{\circ} \mathrm{C} /$ year in Bosnia, Croatia and Slovenia) (Bogdanovic $\&$ Siljic, 2012). Rainfall was very scarce in the 1940s, in the second half of the 1950s and after 1990 (Radeva \& Alexandrov, 2009; Bogdanovic \& Siljic, 2012). Altogether from 1950 to 2006, rainfall across the whole region decreased, with the exception of central-eastern Romania (Bogdanovic \& Siljic, 2012). Similarly, between 1890 and 2000 in the Greater Alpine Region - the portion of the European continent that includes the Alps and the area surrounding them, from the 4th to the 19th meridian east and from the 43rd to the 49th parallel north - the increase in average temperature was $1.4^{\circ} \mathrm{C}$ (Böhm et al., 2001, Brunetti et al., 2009), with more rainfall north of the Alps and a reduction to the south (Efthymiadis et al., 2007).

These factors, together with the more-pronounced general warming of northern areas (Fig. 12), could explain the shift of the northern edge of the breeding range.

Since the beginning of the 20th century, other species

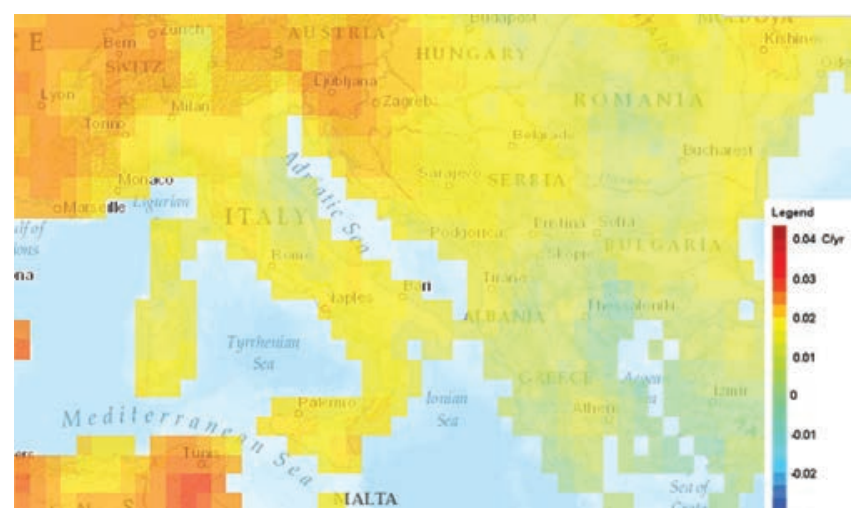

Fig. 12 - Changes in average temperatures $\left({ }^{\circ} \mathrm{C} /\right.$ year $)$ in Europe in the period 1951-2002 (source:http://www.climatewizard.org/). 
apart from the Black-headed Yellow Wagtail have made significant northwards expansions in the Balkans. Among these, sedentary species have been favoured by anthropic factors, enabling them to reach very high latitudes: around the 56th parallel north for the Syrian Woodpecker (Dendrocopos syriacus) (BirdLife International, 2004; 2015a; Michalczuk, 2014) and even to the 70th parallel north for the Eurasian Collared Dove (Streptopelia decaocto) (Hengeveld \& Van den Bosch, 1990; BirdLife International, 2004; 2015a). More interesting is the Eastern Olivaceous Warbler (Hippolais pallida), which, being a trans-Saharan migratory passerine too, is subject to the same biotic and abiotic factors as the Black-headed Yellow Wagtail. The breeding range of this species has expanded northwards just like that of feldegg, going up the Balkans and reaching approximately the border between Hungary and Slovakia, around the 48th parallel north (del Hoyo et al., 2006; BirdLife International, 2015a).

\section{Eastern Europe}

From the mid-1900s, there is a progressive expansion of the Black-headed Yellow Wagtail along the Black Sea coast near the Danube Delta. Its establishment in some areas of the Ukraine around the 49th parallel takes place already in the first half the century. After 1980, the breeding range shifts northwards, reaching the 51st parallel.

Further east, the Orenburg (52nd parallel north) is already the northern-most point of the entire breeding range at the end of the 19th century. Similarly to the Danube Delta, it is an enclave of the feldegg subspecies in an area occupied predominantly by lutea. As for the western part of the area under discussion, only after 1980 does a further northwards progression take place, transiting roughly along the Volga, to around the 55th parallel (Tatarstan).

The terrain of the Danube Delta region is flat and agriculture plays a major role in land use there: agriculture accounts for about $80 \%$ of land use in Moldova and for about $70 \%$ in the Ukraine, and although predominantly arid, almost all land is arable (Nesterenko et al., 2014). There has been a gradual increase in temperature in this area, with effects on the Danube: in the 1961-2010 period, the average annual temperature of the delta's waters increased by $1{ }^{\circ} \mathrm{C}$, with particularly high and steadily increasing levels in summer $\left(0.5^{\circ} \mathrm{C} / 10\right.$ years $)$ (Nesterenko et al., 2014).

Even in Russia there was an average temperature increase of $1^{\circ} \mathrm{C}$ in the $1900 \mathrm{~s}$, that is to say $0.34^{\circ} \mathrm{C}$ more than the mean value for the whole world, with a $0.4^{\circ} \mathrm{C}$ surge in the last decade of the 20th century (Chestin \& Colloff, 2008). This has brought benefits to agriculture by reducing the number of days of bad frost for autumn-sown cereals, stretching the suitable period for the crop by up to 10 days (Chestin \& Colloff, 2008). In the region around Stavropol, grain has shown a 30\% increase in growth (Chestin \& Colloff, 2008). However, there have been difficulties in southern areas - for example near the Black Sea - on account of decreased rainfall (estimated to fall $22 \%$ by 2020) (Roshydromet, 2005). In the 1976-2006 period, European Russia registered the greatest increase in average annual temperature out of the whole Russian Federation (Roshydromet, 2008).
The eastern portion of the European continent covered by the breeding range of feldegg actually coincides with the Pontic Steppe, which stretches from eastern Romania to the Ural Mountains, through southern Moldova, the Ukraine and southern Russia. Especially in these last two areas, the steppe has been transformed over the past 250 years and used for agricultural purposes (Kamp et al., 2011).

Regarding the environmental changes caused by agriculture, the greatest have occurred in recent times in the Ukraine: although agricultural practices remained traditional, the area cultivated shrank $18.3 \%$ between 1985 and 2004 following a strong reduction in the breeding of cattle (-72\% in 2004 compared with 1990) and abandonment of the fields used for forage crops (-61\% from 1990 to 2011) (Anika et al., 2008; Schierhorn et al., 2014). With the fall of the Soviet Union in 1991, there have been important changes even in European Russia: indeed, compared with 1988 , as much as $40 \%$ of agricultural land has been abandoned, transforming first into grassy areas and then partially into forest (De Beurs \& Henebry, 2004; Anika et al., 2008; Schierhorn et al., 2014). Similarly to the Ukraine, the grazing of animals has declined (Robinson \& MilnerGulland, 2003; Kervern et al., 2006) and irrigated cultivated areas have undergone a very significant fall too, reducing to $5 \%$ of the original extension (Hölzel et al., 2002).

These factors have probably determined the abandonment of cultivated areas by the Black-headed Yellow Wagtail in southern Russia and a concentration of the subspecies in depressions along the Don, its tributaries and its delta and along the coast of the Sea of Azov (Muraviev \& Artemyeva, 2014a). In these areas, the breeding habitat is essentially herbaceous and shrubby halophytic grasslands and coastal wetlands (ponds, salt marshes and lagoons) with mesophilic halophyte grasses (Muraviev \& Artemyeva, 2012).

The presence of feldegg in Tatarstan is likely related to the increase in temperatures recorded in the area especially in spring $\left(+3.7^{\circ} \mathrm{C}\right.$ in March, over the last 30 years $)$ and an increase in the already high rainfall. Climate change in Tatarstan had affected also other species, especially their phenology: compared with the 1970s, the Eurasian Skylark (Alauda arvensis) has anticipated its arrival during the spring migration by 11 days (Askeyev et al., 2009a) and, similarly, some species of the genus Sylvia have anticipated arrival by 3-6 days compared with the 1950s (Askeyev et al., 2009b).

\section{The Middle East}

The Middle East has a considerable array of environments: there are humid and semi-humid areas in the north (Turkey and Iran), and increasingly arid conditions proceeding south, culminating in the hyper-arid climate of the Arabian Peninsula (Bonine, 2001; Clarke \& BowenJones, 2013).

Between 1900 and 1990, the land taken up by crops more than tripled (from 19.8 Mha to 63.2 Mha), and pasture more than doubled (from 91 Mha to 206.3 Mha) (Goldewijk, 2001). However, the area used for agriculture in 1996 was only $7.6 \%$ of the total land area of the region, about a quarter of which irrigated (Bonine, 2001). 
There has been a general increase in average temperature in the period $1950-2003$ (from 0.37 to $0.41{ }^{\circ} \mathrm{C} / 10$ years), with a statistically significant increase of the minimum already in the 1970s and an increase in maximum temperature only since the 1990s; rainfall has increased only in Turkey and Iran (Zhang et al., 2005; Lelieveld et al., 2012).

Data on the distribution of the Black-headed Yellow Wagtail in the Middle East is fragmentary up until 1945, and certainly does not describe the real distribution of the taxon in the breeding season, even if all the areas where the bird was sighted have been confirmed in the following decades. Particularly significant is the presence of feldegg in Iran, as evinced from the distribution map in Porter \& Aspinall (2010); however, it is likely that the actual presence of the bird within the highlighted area is much more fragmentary, with its establishment concentrated only in areas suitable for the subspecies. In Iran, the area cultivated is $11.2 \%$ of the total land area: 18.5 Mha is used for agriculture, of which $5.8 \mathrm{Mha}$ is meadow (40\% irrigated), 6.6 Mha is non-irrigated crops and 6.7 Mha is irrigated crops (Siadat, 1998; Qureshi et al., 2007). Non-irrigated crop areas are concentrated mainly in the north-western and western parts, as well as on the coastal strip of the Caspian; agriculture in central and southern Iran is possible only with irrigation, and these areas have been hit by a significant, secondary salinization process that has rendered them poorly productive (Siadat, 1998; Banie, 2001). The distribution of the Black-headed Yellow Wagtail coincides to a large degree with the territory used for pasture and crops (Fig. 13).

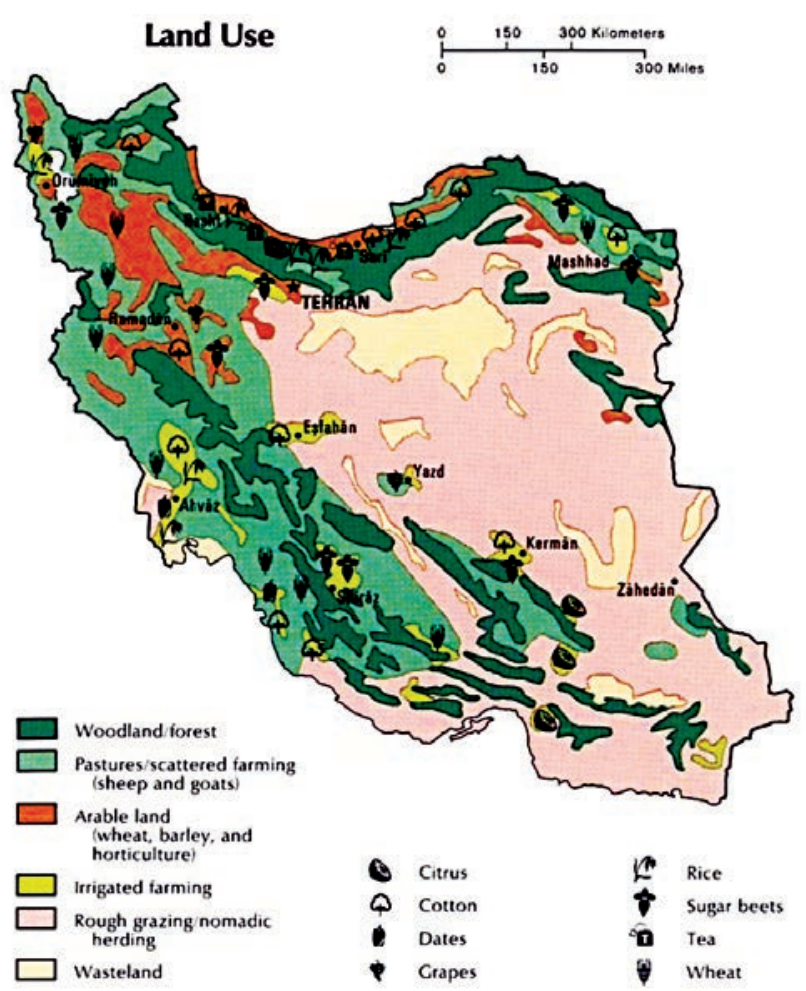

Fig. 13 - Land use in Iran (source: U.S. Central Intelligence Agency, 1993).
The other country with a widespread and sometimes abundant presence of feldegg is Turkey. Historically and currently, the subspecies is concentrated around coastal areas, the catchment areas of rivers and in wetlands. Here, the Black-headed Yellow Wagtail population has undergone a downwards trend, with nesting recently down by 20-49\% (Kiliç \& Eken, 2004; Derneği et al., 2006; BirdLife International, 2015a); a negative trend $(<20 \%)$ is predicted also for the long term (BirdLife International, 2004; 2015a).

Since the 1950s, the taxon has shown a propensity to expand its breeding area south-westwards, and has started to nest in Israel, Lebanon and, possibly, Syria. Indeed, this trend has been consolidated in subsequent decades, and the bird has become regular and locally common in Israel, Lebanon, Syria and Jordan. There do not seem to be any particular biotic or abiotic factors that have favoured the subspecies' establishment in these new territories: the bird has simply colonized existing natural environments, especially humid areas and the margins of large (Euphrates) and small waterways, often in mountainous areas. The expansion of its breeding range towards the south-west, although not particularly extensive, is significant from a quantitative point of view and it stability over time.

A rather particular situation rises at the end of the 1990s in the Arabian Peninsula south of Riyadh: the wagtail starts to nest in artificial agricultural land created in the desert for the Al Safi Dairy. Founded in 1979, it is the largest integrated dairy farm in the world, extending over 3500 ha of land and providing food to a herd of about 37,000 Holstein Friesian cows housed in sheds equipped with cooling systems to make the summer heat endurable. The forage fields are cultivated with Rhodes grass (Chloris gayana), alfalfa (Medicago sativa) and Sudan grass (Sorghum $\times$ drummondii $=$ Sorghum bicolor x Sorghum arundinaceum). Fossil water, essential for irrigation and to quench and cool the animals, is pumped from the aquifer with technology used for oil extraction. The water emerges from wells which are about $2000 \mathrm{~m}$ deep - at a temperature close to boiling point. It is then stored in cooling tanks before being used to water crops with a centre-pivot system, giving the fields the typical circular shape and creating a peculiar green "polka-dot" pattern in the desert (Fig. 14). The sewage and wastewater tanks have created a very favourable condition for the wagtails. At least since 1997, breeding has taken place also in Dubai in a complex of two fields irrigated with the centre-pivot system. The bird's range in the Arabian Peninsula, located between the 25th (Al Safi) and 27th (Dubai) parallel north, is totally separate from its traditional breeding range with the southernmost point in the Fars region of Iran, around the 29th parallel. The southern margin has therefore shifted about $220 \mathrm{~km}$ when taking Dubai into account, and no less than $440 \mathrm{~km}$ in the case of Al Safi. This has been caused exclusively by man-made biotic factors. There is uncertainty about the future of the bird in this area, especially in Saudi Arabia, where agricultural settlements will probably be abandoned upon depletion of the water supply. 


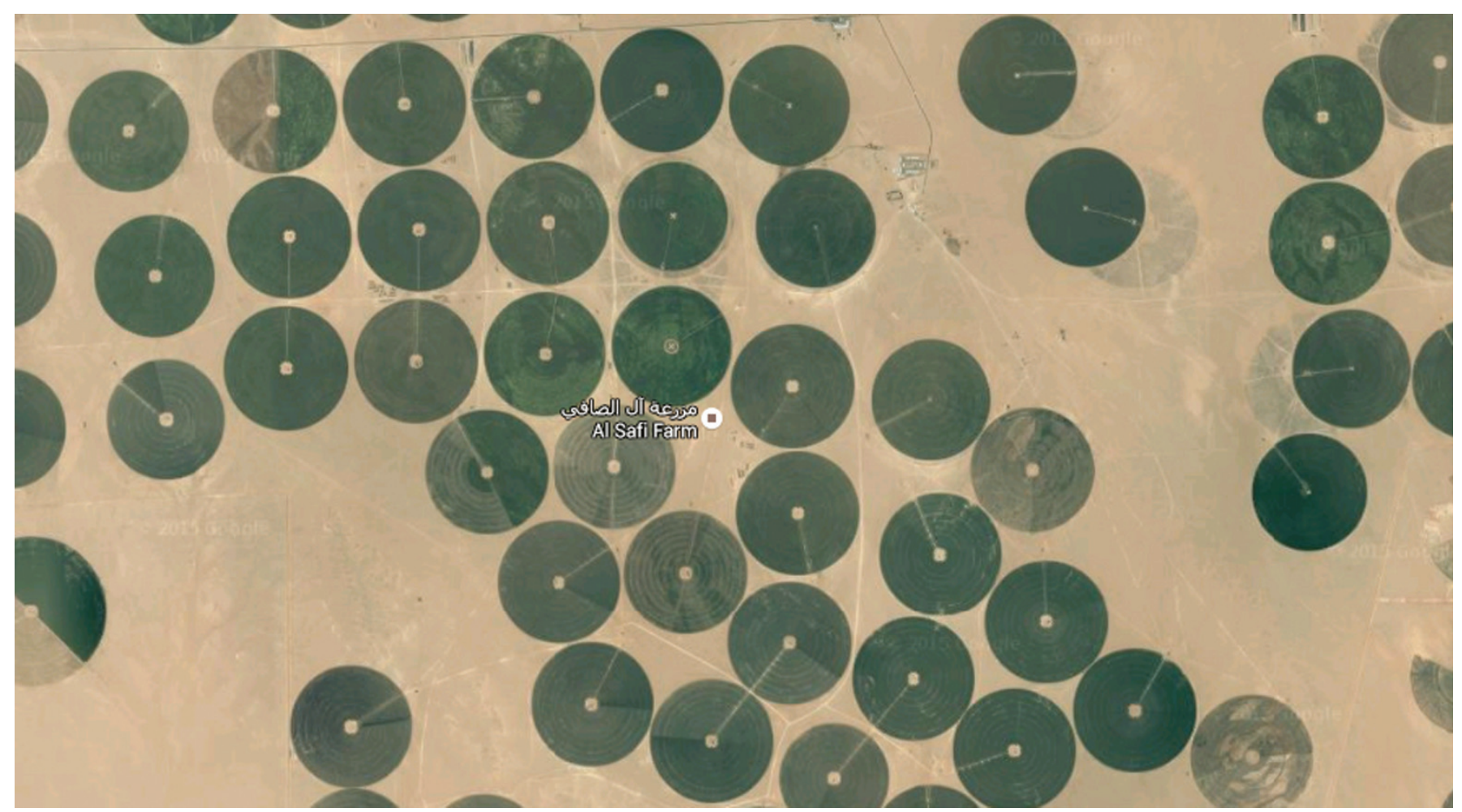

Fig. 14 - Fields irrigated with the center-pivot system at the Al Safi Farm (Saudi Arabia) (source: maps.google.com).

\section{Central Asia}

Between 1950 and 2005, central Asia has undergone an increase in temperature $\left(0.3^{\circ} \mathrm{C} / 10\right.$ years $)$, with heavier rainfall in northern areas (roughly north of the 50th parallel north) and a pronounced drought in the south (especially in the area between the south of Turkmenistan and Uzbekistan and the north of Iran and Afghanistan) (Zavialov, 2005; Jarsjö et al., 2008; Zoï Environment Network, 2009). The temperature increase has been particularly noticeable in the mountains: indeed, the glaciers feeding the major rivers of the region have undergone significant retractions (up to $1 \%$ per year) (Zoï Environment Network, 2009) (Fig. 15).

The increase in anthropogenic activity between 1900 and 1915 caused profound changes already in the 20th

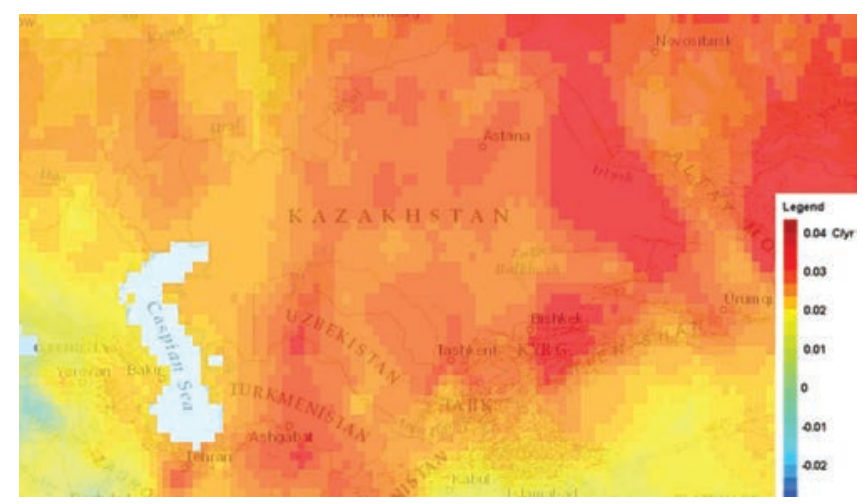

Fig. 15 - Changes in average temperature $\left({ }^{\circ} \mathrm{C} /\right.$ year $)$ in central Asia in the period 1951-2002 (source: http://www.climatewizard.org/). century in all areas between the Aral Sea and the Tien Shan and Pamir mountain ranges (Gâştescu, 2006). Up until 1960, water withdrawal from the rivers feeding the Aral Sea were reasonably limited, producing a reduction of only $81 \mathrm{~cm}$ in the water level from 1911 to 1960 ; however, the lowering of the water level was fast and continuous after 1960, with a decrease of $20 \mathrm{~cm} /$ year from 1961 to $1970,60.4 \mathrm{~cm} /$ year from 1970 to 1990 , and 40.2 $\mathrm{cm} /$ year from 1990 to 1995 (Kravtsova, 2001). Water flow into the Aral Sea, which was about $54 \mathrm{~km}^{3} /$ year in the period 1930-1960, had fallen to $5 \mathrm{~km}^{3} /$ year by 1990 (Zonn et al., 2009). The Amu Darya Delta area of the Aral Sea had 2600 lakes in the 1960s, but already by the mid-1980s the number had reduced to 400 (Kreuzberg-Mukhina, 2006) due to the start of large-scale cultivation programmes between 1954 and 1960 for the so-called "Virgin Lands Campaign" (McCauley, 1976): indeed, about 25 Mha of land was cultivated, needing the construction of approximately $32,000 \mathrm{~km}$ of irrigation canals, 45 dams and more than 80 water reservoirs in the catchment area of the Syr Darya from 1961 onwards (Fig. 16). However, antiquated irrigation techniques using furrows or flooding, which are poorly (about $40 \%$ ) efficient due to evaporation and seepage in the soil during transport, were employed (Edelstein et al., 2012). The land irrigated for agriculture within the basin was about 2 Mha in 1960, 3.3 Mha in 1990 (Bernauer \& Siegfried, 2012), 7.9 Mha in 2010 (Munteanu \& Dârmiceanu, 2010) and is now about 8.4 Mha, according to latest estimates.

Excessive water-use has dramatically reduced the size of the Aral Sea, fragmenting it since 1989 into two portions: the Small Aral to the north, and the Large Aral to 


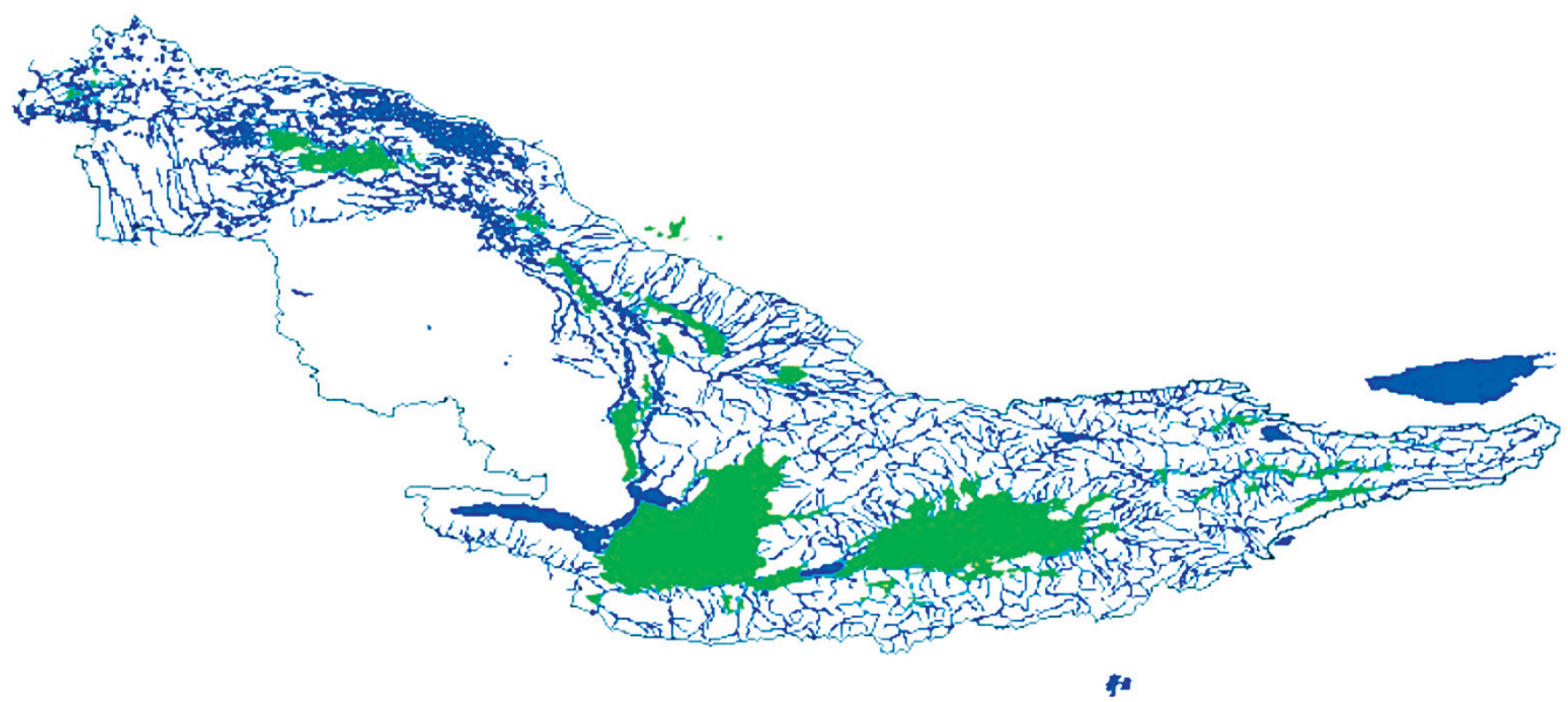

Fig. 16 - The irrigation scheme in the catchment area of the Syr Darya River. Highlighted in green are the most intensively irrigated areas. The irrigated area corresponds roughly with the distribution of the Black-headed Yellow Wagtail (source: Savoskul et al., 2003).

the south. Its surface area has reduced over the past 50 years, from $68,000 \mathrm{~km}^{2}$ to less than $10,000 \mathrm{~km}^{2}$ (Zoï Environment Network, 2009). The drained part of the lake has turned into desert, with dust storms becoming increasingly frequent.

The same outcome could befall Lake Balkhash - which has as main emissary the River Ili, fed by the glaciers of the Tien Shan Mountains in China - due to the large volume of water drawn off for irrigation also there (Kezer \& Matsuyama, 2006; Cirella \& Zerbe, 2014). During the 1980 s, about $70 \%$ of the arid areas surrounding Lake Balkhash were converted to agriculture (Dostay, 2007). In February 1969, a massive flood wave on the Syr Darya exceeded the capacity of the Chardarya Reservoir, further south in Uzbekistan, and flooded the Aydar Depression, unintentionally forming the homonymous lake (surface area, $3000 \mathrm{~km}^{2}$ ) and two other lakes, which together are known as the Aydar-Arnasay Lakes System.

All this has had a significant impact on the breeding range of feldegg. Indeed, the subspecies was originally confined to a few suitable water-rich areas and, although retreating from the Aral Sea area, it has exploited the favourable biotic factors created by the massive irrigation programmes to spread extensively within the drainage basins of the Syr Darya, Amu Darya, Lake Balkhash and the Ili, and south to the Aydar-Arnasay Lakes System. Since 1980, increasing temperatures and rainfall have encouraged its establishment in new areas in the northern TengizKorgalzhyn region of Kazakhstan.

However, the taxon's future in this region is not favourable: in fact, water crises are probable in the drainage basins of the Aral and Balkhash, due to glacier retraction and the abandonment of cultivated areas on account of erosion and soil salinization caused by the irrigation methods employed. Even the recently colonized areas of northern Kazakhstan may become unsuitable for the bird because, with the end of the post-Soviet crisis, agricultural practices have intensified once more since the early 2000 s, producing negative effects on the birds typical of the Steppes (Antonchikov, 2005; Kamp et al., 2011; Kamp, 2012).

On the far eastern edge of Kazakhstan, the taxon appears near the main lake basins in an increasingly regular manner in the second half of the 1900s. In particular, the subspecies has become more stable in the area around Lake Zaysan - after 50 years of sporadic reports, probably due to a very localized, limited presence - tending to travel northwards along the River Irtysh. This is likely connected to the building of a hydroelectric power station on the Irtysh in the 1960s, which has caused the level of Lake Zaysan to rise six metres and increase its surface area from $1800 \mathrm{~km}^{2}$ to $3500 \mathrm{~km}^{2}$.

In the eastern-most portion of the breeding range, within China, the presence of the wagtail has been relatively stable over time. The only novel finding is a sporadic appearance of one migrating individual in Beijing. This single episode is not significant; however, as has happened in Europe, it could be the first sign of an increasing aptitude of the subspecies to expand eastwards.

Its presence in southern Afghanistan seems always rather localized, discontinuous and uncertain.

An unusual sighting occurred near Lake Topar (Almaty Province, Kazakhstan) on 27 May, 2008: a male, probably a Motacilla flava feldegg x Motacilla citreola calcarata hybrid, was seen paired with a female Motacilla citreola (Wassink, 2009). Near the same lake a few days earlier (20 May, 2008) other birdwatchers reported a female Motacilla citreola probably paired with a male Motacilla flava feldegg (De Coster et al., 2008). Up to then, only $M$. citreola x $M$. flava thunbergi hybrids from Norway (Engebretsen \& Pettersen, 2001) and M. citreola x M. flava flava hybrids from western Siberia, were known (McCarthy, 2006). 


\section{CONCLUSIONS}

In the period under study, the Black-headed Yellow Wagtail has expanded its breeding range particularly during the second half of the 20th century. Expansion northwards has been aided by a general increase in temperatures in Europe and Asia, with jump dispersal alternating with phases of diffusion within the newly colonized areas. In the Balkans and western Europe, jump dispersal occurred mainly in the late-19th and mid-20th century. In the eastern portion of its range, jump dispersal occurred most clearly in the last decades of the 20th century and in the early-21st century. The northern limit of the range in Europe (especially eastern Europe) (Fig. 17) and in Asia (Fig. 18) follows with good approximation the $20^{\circ} \mathrm{C}$ isotherm of July.

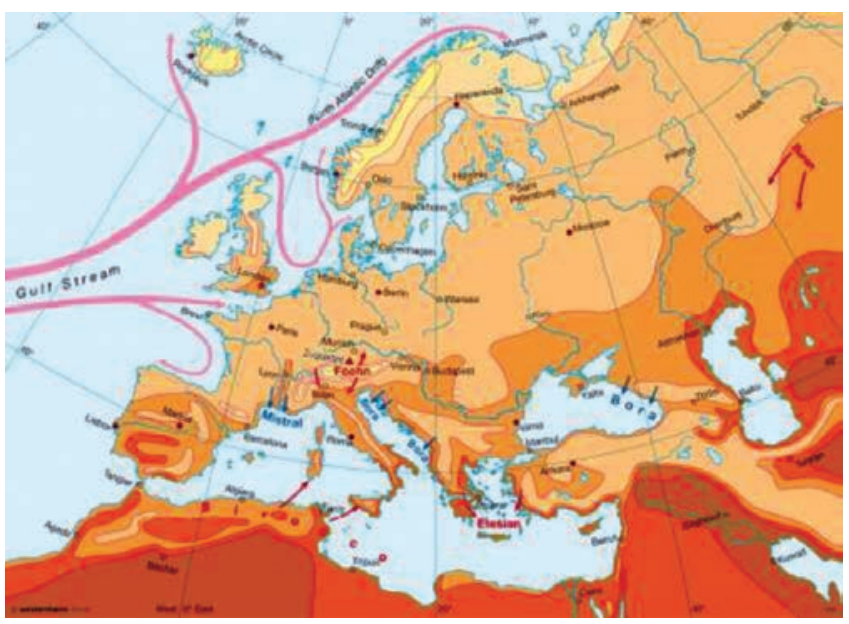

Fig. 17 - July isotherms in Europe (source: Westermann Schulbuch, 2010).

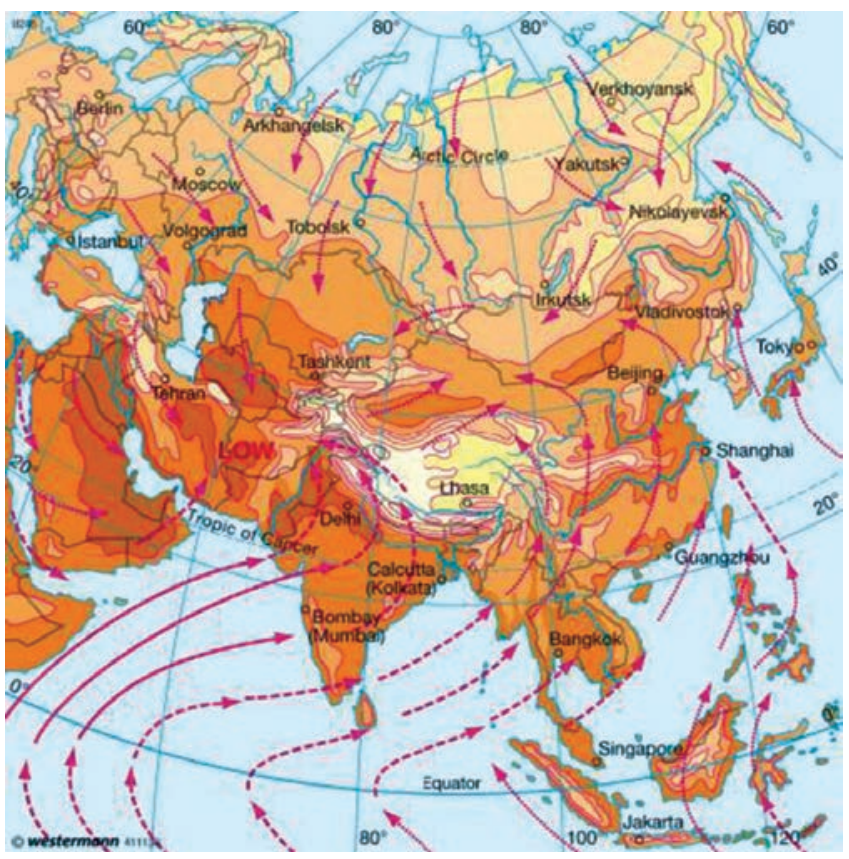

Fig. 18 - July isotherms in Asia (source: Westermann Schulbuch, 2010).
In Europe, there has been also an extension westwards of the nesting sites. Probably as a result of this, the subspecies is following with increasing intensity a new migration route going from Africa to Europe via the Strait of Gibraltar. Concurrently, the appearance of the Black-headed Yellow Wagtail has become increasingly frequent even in northern European countries, and this could be taken as a possible prelude to further expansion. The range of feldegg is, in fact, incorporating on a continental scale the breeding range of cinereocapilla. Indeed, although the Black-headed Yellow Wagtail is a more southern subspecies than the Ashy-headed Yellow Wagtail, in the last few decades it has shown a more marked tendency to migrate northwards than the latter. The overlap with other subspecies is also progressing eastwards. However, feldegg seems to be more selective in its choice of reproductive environments: swamps, grassy areas near lakes, humid areas along sea coasts and river banks. In some areas (for example in the Astrakhan region), it can be found in steppes of Poa $s p$. and poppies growing on red clay soils (Munteanu, 2006; Artemyeva \& Muraviev, 2013). Its predilection for wetlands, including salty ones, is particularly evident observing the locations of its initial colonization in west Europe. These preferences, along with delayed egg laying, determine a certain level of ecological and phenological isolation with respect to other sympatric subspecies (Leisler, 1968; Radu, 1975; 1979; Keve, 1978; Munteanu, 2006; Muraviev, 2013). The breeding areas are usually located within $300 \mathrm{~m}$ of reserves of water used for trophic purpose (Muraviev \& Artemyeva, 2014b). This makes the distribution and abundance of the subspecies rather irregular and determined by the presence of a suitable environment for nesting and nutrition (Muraviev \& Artemyeva, 2014b).

In the Middle East, expansion to the southwest in Israel, Lebanon, Syria and Jordan is diffuse and occurs in almost exclusively natural environments. If the phenomenon continues, it could lead to the colonization of the Egyptian northern wetlands, with the first real contact between feldegg and pygmaea during the breeding season.

Nesting in artificial, man-made contexts in very southern areas of the Arabian Peninsula demonstrates the potential capacity of the subspecies to expand also southwards. In this case, the limiting factor is certainly lack of an appropriate environment given the high prevalence of hyper-arid climes. Colonization by the Black-headed Yellow Wagtail of water-rich grasslands within a desert context totally unsuitable for the species constitutes an implicit confirmation of what has been speculated for $\mathrm{ci}$ nereocapilla, that is, that its occupation of the Po Valley in the late 19th century was related to the widespread development of grasslands to support bovine farming in an environment with an abundant water supply (Ferlini, 2015). Further south in Saudi Arabia, another potentially suitable location is Wadi Al Dawasir $\left(20.2^{\circ} \mathrm{N}, 44.8^{\circ} \mathrm{E}\right)$ : in this case too, there are many centre-pivot-irrigated fields covering a large area (about $30 \times 45 \mathrm{~km}$ ). There do not seem to be reports of the bird in the area, but the context is promising and deserves to be investigated. 
In central Asia - especially in the catchment area, in the broad sense, of the Aral Sea - the spread of the subspecies is obviously caused by human activity, in particular by irrigation of land for agriculture. However, this is an unstable situation because of likely future water crises caused by irrational use of resources and by climate change. At the far eastern edge of the birds' range, there have been no particular movements, whether expansive or recessive; nevertheless, the appearance of a Black-headed Yellow Wagtail in Beijing could indicate possible migratory expansion also in Asia.

\section{Acknowledgements}

I heartedly thank Andrea Corso, Pierandrea Brichetti, Davide D’Amico, Davide de Rosa, Fulvio Fraticelli, Pietro Giovacchini, Giacomo Sgorlon, Filippo Tatino and Domenico Verducci for the information they have kindly supplied. I am also grateful to Egidio Fulco, Beppe Miceli, Andreas Trepte and Günter Wondrak for the photographic material they made available and to Mike Latronico for the English language revision.

I dedicate this work to the memory of the zoologist and physician Karl Michahelles (Nuremburg, May 5, 1807 - Nauplia, August 15, 1834), who described, other than the Black-headed Yellow Wagtail, also the Western Rock Nuthatch (Sitta neumayer) and the Iberian ribbed newt (Pleurodeles waltl), and who died prematurely while studying the natural history of Greece.

\section{REFERENCES}

Abed J.M, 2007 - Status of water birds in restored Southern Iraqui Marshes. Marsh Bulletin, 2 (1): 64-79.

Adizel Ö. \& Durmuş A., 2009 - A study on bird species under threat and avifauna of Erçek Lake (Van-Turkey). Scientific Research and Essay, 4 (10): 1006-1011.

Aksyonov P.V. \& Ermakov A.M., 2014 - Ветеринарная Патология. [Veterinary Pathology]. 2: 127-130.

Albegger E., 2009 - Maskenstelze in der Gallery. Club 300 Austria. $<$ http://www.club300.at/node/15812> (retrieved on December 2015)

Allouse B.E., 1953 - The avifauna of Iraq. Iraq Natural History Museums Pubblication, 3. al-Tafayyudh Press, Baghdad.

Allcock J.B., 2000 - Explaining Yugoslavia. C. Hurst \& Co. Publishers.

Almäsy G.V., 1898 - Addenda zur Ornis Ungarns. II. Über die Formen der Untergattung Budytes. Ornithologisches Jahrbuch, 9 (3): 83112.

Alström P., Mild K. \& Zetterström B., 2003 - Pipits \& Wagtails of Europe, Asia and North America. Identifications and Systematics. Christopher Helm, London.

Alström P. \& Mild K., 2005 - Biologiska, fylogenetiska och monofyletiska arter - skillnader och likheter. Fåglar i Uppland, 31: 12-21.

Alvarez-Cros C., 2012 - Ocells rars a l'Empordà, v. 2. Comitè avifaunistic empordanès. $<\mathrm{http}: / / \mathrm{www}$. comiteempordanes.org/Seguiment/ Ocells_rars_Emporda_v2.pdf $>$ (retrieved on December 2015)

Al-Sirhan A.R., 2015 - KORC annotated checklist of birds. <http:// birdsofkuwait.com/annotated_checklist.shtml> (retrieved on December 2015)

Al-Thahaibawi B.M.H., 1999 - Study of ecological characteristics and biodiversity of Al-Auda Marsh in Maysan Province. Thesis, University of Baghdad.

Ananeva S.I., Babkin N.G., Grandmother G.M., Baranovsky A.V., Zatsarinnyi I.V., Ivanchev V.P., Lobov I.V., Marochkina E.A., Mitin E.I., Sal'nikov S.V., Fionina E.A., Khlebosolov E.I., Hlebosolova O.A., Cheltsov N.V. \& Shemyakin O.A., 2008 - Birds Ryazan Meshchora. Hlebosolova, Ryazan.
Ananian V., 2001 - Trip Reports - Armenia 4th to 15th June 2001. <http:// www.osme.org/trip-reports/armtrip5> (retrieved on December 2015)

Andersen M.W., 2003 - Birding in Kyrgyzstan and Kazakhstan 27.June-20.July 2003. <http://www.netfugl.dk/trip reports/asia/ KasakhstanKirgisien2003Miksture/Kasakhstan_Kirgisien_2003_ Miksture.pdf $>$ (retrieved on December 2015)

Andersen M.W., 2004 - Kyrgyzstan and Kazakhstan 31 May - 25 June 2004. <http://www.netfugl.dk/trip_reports/asia/Kyrgyzstan Kazakhstan_2004/Miksture_kasakhstan_og_kirgisien_2004.pdf $>$ (retrieved on December 2015)

Andersen M.W., 2006 - Birding in Kyrgyzstan and Kazakhstan 21 May - 2 June 2006. <http://www.miksture.com/file/KAKI2006MayJune.pdf $>$ (retrieved on December 2015)

Andersen M.W., 2009 - Birding in Kyrgyzstan and Kazakhstan 1 July - 24 July 2009. <http://www.miksture.com/file/Miksture\%20 KAKI\%202009.pdf> (retrieved on December 2015)

Anderson B., 2007 - Uzbekistan 1-3 May 2007. Tripe report. <http:// www.club300.se/files/travelreports/uzbekistan2007_ba.pdf> (retrieved on December 2015)

Anika S., Kuemmerle T., Uvarov N.V., Pankov A.B., Baskin L.M. \& Radeloff V.C., 2008 - Effects of post-Soviet land-use change on large mammals' habitat in european Russia. Geography Department, Humboldt-Universität zu Berlin.

Anonymous, 1979 - European news. British Birds, 72: 275-281.

Anselin A. \& Tailly M., 2006 - Bird Report: Armenia 06-18 July 2006. $<$ http://users.telenet.be/tailly/armenia2/armeniabirds2006.htm $>$ (retrieved on December 2015)

Antonchikov A.N., 2005 - A review of the conservation status of steppe birds of the northern part of the Eastern Palearctic. In: Ecology and conservation of Steppe-land birds. Bota G, Morales M., Manosa S. \& Camprodon J. (eds.). Lynx, Barcelona: 103-118.

Ararat K., Fadhil O., Porter R.F. \& Salim M., 2011 - Breeding birds in Iraq: important new discoveries. Sandgrouse, 33 (1): 12-33.

Arcamone E. \& Puglisi L., 2006 - Cronaca ornitologica toscana. Osservazioni relative agli anni 1992-2004. Alula, 13 (1-2): 3-124.

Arkhipov V.Y., Rusanov G.M. \& van Steenis M., 2003 - K авифауне северо-западного прикаспия: новые находки и уточнения статуса видов. Бюл. Моск. О-ва испытателей природы, 108 (2): 17-24.

Arlott N. \& Khrabryı̆ V., 2009 - Ptitsy Rossii: spravochnik-opredelitel. Amfora, San Pietroburgo.

Arrigoni degli Oddi E., 1898 - Uccelli rari o più difficili ad aversi osservati nella sua collezione ornitologica italiana al 31 dicembre 1898. Ornis, 9: 199-249.

Arrigoni degli Oddi E., 1899 - Note ornitologiche sulla Provincia di Verona. Atti della Società Italiana di Scienze Naturali e del Museo Civico di Scienze Naturali di Milano, 38: 75-190.

Arrigoni degli Oddi E., 1902 - Atlante ornitologico. Uccelli europei con notizie d'indole generale e particolare. Ulrico Hoepli Editore, Milano.

Arrigoni degli Oddi E., 1929 - Ornitologia Italiana. Ulrico Hoepli Editore, Milano.

Artemyeva E.A. \& Muraviev I.V., 2013 - Симпатрия «желтых» трясогузок (Passeriformes, Motacillidae, Motacillinae). Ulyanovsk State Pedagogical University, Ulyanov.

Artemyeva E.A. \& Muraviev I.V., 2014 - Breeding biology of Blackheaded Wagtail Motacilla feldegg Michahhelles, 1830 (Passeriformes, Motacillidae, Motacillinae) in South of Russia. International Journal of Biology, 6 (2): 21-30.

Aschenbrenner L., 1975 - Erstbrut der Maskenstelze (Motacilla flava feldegg) in Rust am Neusiedler See. Egretta, 18 (1): 22-23.

Askeyev O.V. \& Askeyev I.V., 1999 - Орнитофауна Республики Татарстан (конспект современного состояния). Академия Наук Татарстана Институт Экологии Природных Систем Казанская Государственная Академия Ветеринарной Медицины Союз Охраны Птиц России. Kazan.

Askeyev O.V., Sparks T.H. \& Askeyev I.V., 2009a - Earliest recorded Tatarstan skylark in 2008: non-linear response to temperature suggests advances in arrival dates may accelerate. Climate Research, 38: $189-192$.

Askeyev O.V., Sparks T.H., Askeyev I.V. \& Tryjanowski P., 2009b Spring migration timing of Sylvia warblers in Tatarstan (Russia) 1957-2008. Central European Journal of Biology, 4 (4): 595-602. 
Aslan A. \& Kiziroğlu 1́., 2003 - A Study on the ornithofauna of Sakaryabaşi/Eminekin Pond and its vicinity. Turkish Journal of Zoology, 27: 19-26.

Aspinall S., Sultanov E. \& Babayev I., 2001 - Environmental baseline study of the BP Sangachal terminal area. Ornithology. Results of a breeding bird survey conducted during May 2001. In: Azeri, Chirag \& Gunashli full field development Phase 1. Environmental \& Socio-economic Impact Assessmen, BP.

Aspinall S. \& Hellyer P., 2003 - UAE twitchers guide for the week ending 6 June 2003. United Arab Emirates.

Autori Vari, 2008 - Atlante della Biodiversità della Sicilia: Vertebrati terrestri. Studi e Ricerche, 6. Arpa Sicilia, Palermo.

Averin V.G., 1911 - Ornitologicheskie nabloudenie letom 1909/1910 g v okresnoteakh ctantsii Miteanskoi Donetskovo okrouga. [Ornithological observations, summer 1909/1910 near the Metsansky station, Donetsk region]. Troudi o-va ispit Prirodi, 44: 258-287.

Aymí R., 1999 - Identification of adult male yellow wagtails in winter plumage in western Europe. Dutch Birding, 21: 241-253.

Babbington J., 2014 - Breeding Yellow Wagtails? Sabkhat Al Fasl. $<$ http://www.birdsofsaudiarabia.com/2014/08/breeding-yellowwagtails-sabkhat-al-fasl.html> (retrieved on December 2015)

Balfour E.G., 1858 - Birds of Eastern and Southern Asia.

Balmer D. \& Betton K., 2003 - Around the region. Sandgrouse, 25 (2): 154-159.

Banie M.H., 2001 - Soil map of Iran. Land resources and potentialities. Soil and Water Research Institute, Tehran.

Barthel P.H. \& Helbig A.J., 2005 - Artenliste der Vögel Deutschlands. Limicola, 19 (2): 89-111.

Batty C., 2004 - Armenia and Georgia 24th June-3rd July 2004. <http:// www.birdtours.co.uk/tripreports/armenia/arm1/arm-georgia-june04.htm > (retrieved on December 2015)

Beaman M., 2013 - Tibet \& Xinjiang 18/22 July-10 August 2013. $<$ http://www.birdquest-tours.com/pdfs/report/Tibet $\% 2013 \% 20$ report $\% 201001$.pdf $>$ (retrieved on December 2015)

Belik P., Vetrov V.V. \& Milobog Y.V., 2009 - Data on avifauna of Taman' Peninsula. Branta, 12: 7-26.

Belis W. \& Olioso G., 2011 - Aperçu diachronique de l'avifaune provençale. Faune-PACA Publication, ${ }^{\circ} 9$.

Belogorsky Eco-center, 2013 - Ecological Network. <http://www. krimspec.org/ecologiya/ecologset/763-ekotsentry-regionalnojekologicheskoj-seti-ark-belogorskij-predgornyj-ekotsentr.html> (retrieved on December 2015)

Beniston M., 2013 - European isotherms move northwards by up 15 $\mathrm{Km}$ year-1: using climate analogues for awareness-raising. International Jounal of Climatology. < doi: 10.1002/joc.3804>

Benoit L., 1840 - Ornitologia siciliana, o sia Catalogo ragionato degli uccelli che si trovano in Sicilia. Stamperia di Giuseppe Fiumara, Messina.

Beretzk P., 1956-57 - Kucsmás billegető a szegedi Fehértón. Aquila, 63-64: 304.

Berezovukov N., 2006 - Alakolsky state nature zapovednik. In: Strict nature reserves of Central Asia. Nature protected areas of Central Asia, Nr. 1. Jashenko R.V. (ed.). Tethys, Almaty.

Bergier P., Franchimont J., Thevenot M. \& CHM, 2006 - Les oiseaux rares au Maroc. Rapport de la commission d'homologation marocaine. Numéro 11 (2005). Go-South Bulletin, 3: 31-42.

Bernauer T. \& Siegfried T., 2012 - Climate change and international water conflict in Central Asia. Journal of Peace Research, 49 (1): 227-239.

Bertilsson P.A., 2004 - First breeding of Yellow Wagtail in Arabia. The Phoenix, 20: 1-2.

Beskaravayny M.M., 2001 - Distribution in biotopes of birds, breeding in the eastern part of the rocky Crimea. Branta, 4: 42-70.

Beskaravayny M.M, 2007 - Towards southern borders of distribution of some elements of breeding ornithofauna of the plains and foothills of the Crimea. Branta, 10: 7-26.

Besserer F., 1899 - Budytes borealis Sund, in Bayern. Jahresbericht des Ornithologischen Vereins München für 1897 und 1898: 153-155.

Birch G., 2010 - Birdwatching on the Silk Road. A trip to Uzbekistan \& Kazakhstan. The Adjutant, 31: 52-77.

BirdLife Cyprus, 2001 - Cyprus annual bird record 2000. BirdLife Cyprus.
BirdLife Finland, 2015 - All records accepted by the Finnish Rarities Committee. $\quad<$ http://www.birdlife.fi/havainnot/rk/rk-data4.shtml $>$ (retrieved on December 2015)

BirdLife International, 2004 - Birds in Europe: population estimates, trends and conservation status. BirdLife International, BirdLife Conservation, series no: 12, Cambridge, UK.

BirdLife International, 2015a - IUCN red list for birds. $<$ http://www. birdlife.org > (retrieved on December 2015)

BirdLife International, 2015b - Important bird areas factsheet: Kattakurgan reservoir. <http://www.birdlife.org $>$ (retrieved on 16/02/2015)

Blanford W.T., 1867 - Eastern Persia, Zoology \& Geology, Vol. II. Macmillan and Co., London.

Blanford W.T., 1876 - Zoology and Geology of Eastern Persia - Vol. 2. Journeys of the Persian Boundary Commission, Macmillan, London.

Blomdahl A., 2006 - Kazakstan 23 maj - 9 juni 2006. <http:// www.cloudbirders.com/tripreport/repository/AVIFAUNA_ Kazakhstan 05 2006.pdf> (retrieved on December 2015)

Blomdahl A., 2014 - Turkestan, Kazakstan, Kyrgyzstan \& Uzbekistan. 10-29 may 2014. Trip report. <http://birdlife.se/avifauna/rapporterarkiv/reserapporter/asien/kirgizistan/> (retrieved on December 2015)

Blondel J. \& Isenmann P., 1981 - Guide des oiseaux de Camargue. Delachaux \& Niestlé, Paris.

Blum V., 1968 - Maskenstelzen (Motacilla flava feldegg) in Österreich. Erfolgreiche Brut einer Maskenstelze (Motacilla flava feldegg) im Rheindelta (Vorarlberg). Egretta 11: 1-2.

Blum V., 1970 - Auch 1969 wieder eine Maskenstelzenbrut im Rheindelta. Egretta 13 (2): 58-59.

Bochenski Z., 1960 - Ptaki Pienin. Acta Zoologica Cracoviensia, 10: 349-445.

Bogdanow M.N., 1879 - Птицы Кавказа. Труды общества есте ствоиспытателей при императорском Казанском университете, Kazan.

Bogdanovic J. \& Siljic A. (eds.), 2012 - West balkan environmental core set of indicators. Zoï Environment Network, Geneva.

Böhm R., Auer I., Brunetti M., Maugeri M., Nanni T. \& Schöner W., 2001 - Regional temperature variability in the european Alps: 1760-1998 from homogenized instrumental time series. International Journal of Climatology, 21: 1779-1801.

Böhr H.-J., 1962 - Zur Kenntnis der Vogelwelt von Korfu. Bonn Zoological Bulletin - früher Bonner Zoologische Beiträge, 13: 50-114.

Bonaparte C.L., 1832-1834 - Iconografia della fauna italica. Fascicolo VII. Mammiferi e uccelli, Roma.

Bonine M.E, 2001 - Agricultural development or sustainable agriculture: the case of the Middle East. In: Rural development in Eurasia and the Middle East. Land reform, demographic change, and environmental constraints. Engelmann K.E. \& Pavlakovic V. (eds.). University of Washington Press.

Borodin O.V., 2002 - О пользе полевых дневников и тщательности - Природа Симбирского Поволжья. Сборник научных трудов, 3: 169-171.

Borodin O.V., 2006 - The dynamics of the avifauna of the Ulyanovsk region. (Russia, Middle Volga region) at the end of XX and beginning of XXI century. Ornithological studies in North Eurasia: Tez. XII Intern. Ornitol. Conf. Northern Eurasia. Stavropol; 85-86.

Borodin O.V., Barabashin T.O. \& Glebov A.M., 2007 - List of birds of the Ulyanovsk region: 30 years later. The study of birds in the territory of the Volga-Kama region: materials All-Russia. Scientific and Practical Conf. Ecol. Vestnik. Chuvashia. Republic. Cheboksary, 57: 16-21.

Boscain L. \& Biasioli M., 2014 - Check-list of birds of the Ultima Frontiera property (last upload on September 2014). Skua Nature Group. <http://www.skuanature.com/skua nature/ULTIMA FRONTIERA_files/UF_CHECKLIST_BIRDS.p.pdf $>$ (retrieved on December 2015)

Boutin J. \& Cherain Y., 1989 - Compte rendu ornithologique Camarguais pour les années 1986-1987. Revue d'Ecologie (Terre Vie), 44: 165-189.

Bozic I.A., 1996 - Srecanja z rumeno pastirico Motacilla flava (Encounter with the Yellow Wagtail Motacilla flava). Acrocephalus, 74: $25-27$.

Brandt T., 2005 - Kazakhstan trip report. <www.cloudbirders.com>

Braun F., 1908 - Unsere Kenntnis der Ornis der Kleinasiatischen. Westküste Journal für Ornithologie, 56: 539-626.

Brichetti P., 1976a - Atlante Ornitologico Italiano. Scalvi Editori, Brescia. 
Brichetti P., 1976b - Gli uccelli del Bresciano. Rivista Italiana di Ornitologia, 46: 33-39.

Brichetti P., Cagnolaro L. \& Spina F., 1986 - Uccelli d'Italia. Giunti, Firenze.

Brichetti P. \& Fracasso G., 2007 - Ornitologia Italiana. Vol. IV. Alberto Perdisa Editore.

British Ornithologists' Union, 1915 - A list of British Birds. British Ornithologists'Union.

Brunetti M., Lentini G., Maugeri M., Nanni T., Auer I., Böhm R. \& Schöner W., 2009 - Climate variability and change in the greater Alpine Region over the last two centuries based on multi-variable analysis. International Journal of Climatology, 29: 2197-2225.

Brunner H., 1986 - Kurzmitteilung: Zwei Brutnachweise der Maskenstelze, Motacilla flava feldegg Michahelles, für Steiermark und Kärnten (Aves). Mitteilungen der Abteilung für Zoologie am Landesmuseum Joanneum Graz, 38: 57-58.

Buchko V.V., Skilsky I.V. \& Shkolny I. S., 1996 - Avifaunistic finds in Chernivtsi region. Berkut, 5 (2): 201-208.

Buchner O., 1922 - Specht-Naumann. Die Vogel Europas. Lutz, Stuttgart.

Buturlin S.A., Geptner V.G., Dementiev G.P., Zhitkov B.M., Ognev S.I., Promptov A.N., Turov S.S., Formozov U.N., Shulpin L.M., Formozov A.N. \& Zhitkova B.M., 1940 - Птицы. Животный мир СССР. Детиздат, Москва-Ленинград.

Cambi D., 1982 - Ricerche ornitologiche in provinvia di Foggia (zone umide Gargano) dal 1964 al 1981. Rivista Italiana di Onritologia, 52: 137-153.

Cardy P. \& Kolbintsev V., 2002 - The Altai Mountains where four worlds meet. Trip report 18th July to 2nd August 2002. <http:// www.cloudbirders.com/tripreport/repository/GREENTOURS Kazakhstan_0708_2002.pdf $>$ (retrieved on December 2015)

Caterini F. \& Ugolini L., 1953 - Il libro degli uccelli italiani. Editoriale Olimpia, Firenze.

Cãtuneanu I., Pascovschi S., Papadopol A. \& Tãlpeanu M., 1962 L'expansion de Motacilla flava feldegg Mitch. (Aves) dans le sudest de l'Europe. Travaux du Muséum d'Histoire Naturelle "Grigore Antipa", 3: 317-340.

Celmiņš A., Baumanis J. \& Mednis A., 1993 - List of Latvian Bird Species 1993 (including the Latvian RC report 1988-1992). Latvijas Ornitofaunistikas Komisija (OFK), Eastbird.

Chesneau J., 1983 - Estivage d'une Bergeronnette printanière de la sous-espèce feldegg (Motacilla flava feldegg). Bulletin de l'Association des naturalistes orléanais, 2 (1): 35.

Chestin I.E., 2014 - Integrated environmental survey of the territory Yashkulsky and Chernozemelsky District Republic of Kalmykia, justifying the creation of state nature reserves of regional significance "Saiga".

Chestin I.E. \& Colloff N.A., 2008 - Russia and neighbouring countries: environmental, economic and social impacts of climate change. WWF Russia, Oxfam.

China Animal Scientific Database, 2013 - <http://www.zoology.csdb. $\mathrm{cn} /$ page/showItem.vpage? $\mathrm{id}=$ cnbird.tableDist/13BAD331-BB294A90-8DD7-2F162F123D5F> (retrieved on December 2015)

Chişamera N., 2007 - Preliminary data on the avifauna of the lower sector of the Cricovul Dulce river. Drobeta, 17: 229-236.

CHN, 2015 - Base de données du CHN. Comité d'Homologation National - France. <http://www.chn-france.org/chn_donnees.php> (retrieved on December 2015)

Chytil J., 1995 - 5. zpráva Faunistické komise ČSO (5th report from the Czech Rarities Committee). Zpravy CSO, 41: 17-20.

Cirella G.T. \& Zerbe S., 2014 - Sustainable water management and wetland restoration strategies in Northern China. Bozen-Bolzano University Press.

Clarke G.H., 1924 - IV. Some notes on birds found breeding in the neighbourhood of Aleppo in 1919. Ibis, 66 (1): 101-110.

Clarke J.I. \& Bowen-Jones H. (eds.), 2013 - Change and development in the Middle East. Routledge, Oxon.

Clarke T., Orgill C. \& Disley T., 2006 - Field guide to the birds of the Atlantic Islands. Christopher Helm, London.

Club300 Deutschland, 2015 - Rarities Germany. Maskenschafstelze. $<$ http://www.club300.de/alerts/index2.php? mode=1\&val=614> (retrieved on December 2015)
Collinson J.M. \& McGovan R.Y., 2011 - Hastings Rarities in the Royal Museum of Scotland, Edinburgh. British Birds, 104: 542-546.

Corso A., 2005 - Avifauna di Sicilia. Epos, Palermo.

Cova C., 1969 - Atlante degli uccelli d'Italia. Hoepli, Milano.

Csörgey T., 1903 - Faunistische und Zugsdaten aus Dalmazien. Zusammengestellt aus den früheren Publicationen und weltlichen Mittheilungen des Professors Georg Kolombatovic. Aquila, 10: 82-103.

Csörgő T., 1975 - Kucsmás sárgabillegető (Motacilla flava feldeggi) Mezőkövesden. Aquila, 82: 237.

Curzon R., 1854 - Armenia: a year at Erzeroom, and on the frontiers of Russia, Turkey, and Persia. John Murray, London.

De Beurs K. \& Henebry G., 2004 - Land surface phenology, climatic variation, and institutional change: analyzing agricultural land cover change in Kazakhstan. Remote Sensing of the Environment, 89: 497-509.

De Coster F., De Maere K., Depotter P., D’Haeseleer W., Faveyts W., Heip J., Mertens J. \& Mertens W., 2008 - Verslag trip Kazachstan 13-30 mei 2008. <http://vwg.natuurkoepel.be/archief/Kazachstan2008.pdf> (retrieved on December 2015)

de Filippi F., 1865 - Note di un Viaggio in Persia nel 1862. Daelli \& C. Editori, Milano.

de Juana A.E. \& Comité Ibérico de Rarezas de la S.E.O., 1989 - Observaziones homologadas de aves raras en Espaňa y Portugal. Informe de 1987. Ardeola, 36: 111-123.

de Juana A.E. \& Comité Ibérico de Rarezas de la S.E.O., 1990 - Observaziones homologadas de aves raras en Espaňa y Portugal. Informe de 1988. Ardeola, 37: 107-125.

de Juana A.E. \& Comité Ibérico de Rarezas de la S.E.O., 1993 - Observaziones homologadas de aves raras en Espaňa y Portugal. Informe de 1991. Ardeola, 40: 177-192.

de Juana A.E. \& Garcia E., 2015 - The Birds of the Iberian Peninsula. Christopher Helm, London.

De Serres M., 1845 - Des causes des migrations des divers animaux et particulièrement des oiseaux et des poisons. Paul Lechevalier, Paris.

De Smet G., Vandegehuchte M. \& BAHC, 1998 - Zeldzame zangvogels in België in 1996 en 1997. Oriolus, 20: 1-35.

De Smet G., Adriaens P., Vandegehuchte M. \& BAHC, 2006 - Lijst van de Belgische vogels. Belgisch Avifaunistisch Homologatiecomité (BAHC).

Degland C.D., 1840 - Catalogue des oiseaux observés en Europe, principalement en France, et surtout dans le nord de ce royaume - 2.e Ordre. Société Royale des Sciences, de l'Agriculture et des Arts à Lille: 169-282.

Degland C.D., 1849 - Ornithologie européenne, ou Catalogue analytique et raisonné des oiseux observés en Europe, Vol. I. Paris.

Deliry C., 1986 - Observations exceptionnelles à l'étang de Haute-Jarrie à 4 jours d'intervalle: le Gobemouche nain (Ficedula parva) et la Bergeronnette printanière des Balkans (Motacilla flava feldegg). La Niverolle, 10: 33-35.

del Hoyo J., Elliott A. \& Christie D., 2006 - Handbook of the birds of the World, vol. 11. Old World Flycatchers to Old World Warblers. Lynx Edicions, Barcelona.

Dementiev G.P., 1937 - Songbirds. In: Complete checklist of birds of the USSR. Buturlin S.A. \& Dementiev G.P. (eds.). Moscow and Leningrad.

Dementiev G.P. \& Gladkov N.A. (eds.), 1954 - Ptitsy Sovyet Soyuza. [The birds of the Soviet Union]. Vol. 5. Sovetskaya Nauka, Moskva.

Demidov A., 1840 - Voyage dans la Russie meridionale et la Crimee, par la Hongrie, la Valachie et la Moldavie. Vol. III. Ernest Bourdin et Ce., Paris.

Derneği D., Eken G., Bozdoğan M., İsfendiyaroğlu S., Kılıç D.T. \& Lise Y., 2006 - Key biodiversity areas of Turkey. [Türkiye'nin Önemli Doğa Alanları]. Doğa Derneği, Ankara.

Desfayes M., 1986 - Inventaire des oiseaux du Valais: mise à jour 1986. Bulletin de la Murithienne, 104: 3-23.

Desfayes M. \& Praz J.C., 1978 - Notes on habitat and distribution of montane birds in Southern Iran. Bonner Zoologische Beiträge, 29: 18-37.

Despott G., 1928 - Elenco sinottico degli uccelli che visitano queste isole di Malta e Gozo col loro nome scientifico, nome volgare Maltese coll'indicazione dei sedentarii, degli avventizi, degli accidentali, dei nidificanti ed altre osservazioni, compilato da Nicola Ardoino il 1mo febbrajo 1893. Archivum Melitense, 7: 128-160. 
Deutsch M., 1985 - Maskenstelze Motacilla flava feldegg am Chiemsee. Ornithologischer Anzeiger, 24 (2-3): 186.

Deutsch-Reitinger M. \& Frank A., 1996 - Maskenstelze (Motacilla flava feldegg) an der Salzach. Avifaunistischer Informationsdienst Bayern, 3: 49-50.

Dickson E.D. \& Ross H.J., 1839 - A collection of Bird-skins fron the neighbourhood of Erzeroom. Proceedings of the Zoological Society of London, Part VII: 119-123.

Dies J.I., García E., Gorospe G., Gutiérrez R., Lorenzo J.A., MartíAledo J., Gutiérrez P. \& Vidal C., 2008 - Lista de rarezas de España taxones de aves sometidos a homologación por el comité de rarezas de SEO/BirdLife. Actualización de 2008. <http://www.rarebirdspain.net/homolog 2006.pdf> (retrieved on December 2015)

Diesselhorst G., 1962 - München Anmerkungen zu zwei kleinen Vogelsammlungen aus Iran. Stuttgarter Beiträge zur Naturkunde, 86: 1-29.

Doderlein P., 1871 - Avifauna del Modenese e della Sicilia, ossia catalogo ragionato e comparativo delle varie specie di uccelli che si rinvengono in permanenza o di passaggio nelle provincie di Modena, Reggio (Emilia) e della Sicilia. Giornale delle scienze naturali ed economiche di Palermo, VI: 187-236.

Dolgushin I.A., 1940 - Материалы по фауне птиц Северного Прибалхашья и Казахского нагорья. Известия Казахстанского филиала АН СССР, серия зоологическая, выл. 2. Алма-Ата.

Dolgushin I.A., Korelov M.I., Kuzmina M.A., Kovshar A.F., Borodikhin I. \& Rodionov E.F., 1970 - Birds of Kazakhstan. Vol. 3. Nauka Publishing House of the Kazakh SSR, Alma-Ata: 341-347.

Dombrowski R.R., 1910 - Ornis Romaniae - Die Vogelwelt Rumănien's Sistematisch und Biolog1sch-Geographisch Beschrieben. Buletinul Societății de Șciințe din Bucureșci, România, 19: 659-1146.

Doming H., 1952-55 - Black-headed Wagtail at Csömör, east of Budapest. Aquila, 59-62: 448.

Dortu C., 2011 - South East Kazakhstan and Tengiz-Korgalzhyn natural reserve, May 21st - June 3rd 2011 with Central Asia birding. $<$ http://www.cloudbirders.com/tripreport/repository/DORTU_Kazakhstan_EN_0506_2011.pdf $>$ (retrieved on December 2015)

Dorzhiev T.Z., 2011 - Птицы Байкальской Сибири: Систематический Состав, Характер Пребывания И Территориальное Размещение. [Birds of Baikal Sibiria: systematic composition, character of staying and territorial distribution]. Байкальский Зоологический Журнал [Baikal Zoological Journal], 1 (6): 30-54.

Dostay Ž.D., 2007 - Wasserressourcen und deren Nutzung im IliBalchaš Becken. [Discussion Papers] Zentrum für Internationale Entwicklungs- und Umweltforschung, 34.

DresserH.E., 1902-Amanual of palæarctic birds. PartI.Dresser, London.

Dresser H.E., Keulemans J.G., Neale E., Sharpe R.B., Thorburn A. \& Wolf J., 1871-1881 - A history of the birds of Europe including all the species inhabiting the western palaearctic region. Dresser \& $C$., London.

Dubois P.J., 2006 - Syrie 20 au 30 avril 2006. <https://www.lpo.fr/images/voyagesornithos/Syrie/Syrieavril2006copie.pdf> (retrieved on December 2015)

Dubois P.J., 2007 - Géorgie 1er au 7 juillet 2007. <http://www.lpo. fr/images/voyagesornithos/georgie/georgiedubois2007.pdf> (retrieved on December 2015)

Duda E. \& Leisler B., 1968 - Maskenstelzen (Motacilla flava feldegg) in Österreich. Weitere Feststellungen der Maskenstelze (Motacilla flava feldegg) im Neusiedler-See-Gebiet. Egretta, 11: 4-5.

Dudkin O., 2004 - Survey of habitat conditions for aquatic warbler at key wetland sites in the steppe zone of Ukraine. Ukrainian Union for Birds Conservation, Kyiv.

Durnev Y.A., Kornilova O.A. \& Mandzhiev K.B., 2013 - Материалы по фауне и населению птиц степной части заповедника «Черные Земли» (Республика Калмыкия): поздневесенний и гнездовой аспекты. [Materials on the fauna and composition of birds of the steppe part of Chyornye Zemli Nature Reserve (Republic of Kalmykia): late spring and nesting aspects]. Функциональная морфология, экология и жизненные циклы животных. Сборник научных трудов кафедры зоологии РГПУ им. А. И. Гериена, 13: 45-75.

Durnev Y.A., Kornilova O.A. \& Mandzhiev K.B., 2014 - Птицы заповедника «Черные Земли» (северный прикаспий): поздневесенний и гнездовой аспекты Фауны и населения. Baikalskij Zoologičeskij Žurnal: 1: 53-68.
Dutch Avifauna, 2015 - Balkankwikstaart, Motacilla feldegg, Blackheaded Yellow Wagtail. <http://www.dutchavifauna.nl/species/ balkankwikstaart?all=1\#records $>$ (retrieved on December 2015)

Dzhanmirzoev G.S, Boukreev S.A. \& Nasrulaev N.I., 2010 - Птицы дельты Терека. История изучения и видовой состав. Труды государственного природного заповедника «Дагестанский», 3: 117-132.

ECODIT, 2015 - Strategic environmental Aassessment for the new water sector strategy for Lebanon. Final SEA Report.

Economidou E., Vassilakis K., Bousbouras D. \& Witte R., 1993 - Assessment of the ecological value of the Kalamas River Delta and preliminary management proposals. Preliminary report on 1992. The Goulandris Natural History Museum, Thessaloniki.

Edelstein M.R., Cerny A. \& Gadaev A. (eds.), 2012 - Disaster by design: the Aral Sea and its lessons for sustainability. Researc in social problems and pubblic policy. Vol. 20. Emerald Group Publishing Limited.

Efthymiadis D., Jones P.D., Briffa K.R., Böhm R. \& Maugeri M., 2007 Influence of large-scale atmospheric circulation on climate variability in the greater Alpine Region of Europe. Journal of Geophysical Research, 112, D12104: 1-19.

Engebretsen S. \& Pettersen M., 2001 - Østfold neste stopp? Sitronerle Motacilla citreola. Natur i Østfold, 20 (1/2): 3-7.

Enyedi G., 1967 - The changing face of agriculture in eastern Europe. Geographical Review, 57 (3): 358-372.

Erdoğdu E., 2001 - A Study on the Ornithofauna of Doğanci Pond in Alpu-Eskiflehir. Turkish Journal of Zoology, 25: 105-109.

European Environment Agency, 2010 - Annual european union greenhouse gas inventory 1990-2008 and inventory report 2010. EEA Technical Report 6/2010.

Evans A.H., 1916 - The birds of Britain: their distribution and habits. Cambridge University Press, Cambridge.

Eversmann E.F. \& Lichtenstein H., 1823 - Reise von Orenburg nach Buchara. E.H.G. Christiani, Berlin.

Fatio V. \& Studer T., 1913 - Catalogue des Oiseaux de la Suisse. Vol. X. Ginevra.

Faunistyczna K., 2009 - Rzadkie ptaki obserwowane w Polsce w roku 2008. Notatki Ornitologiczne, 50: 111-142.

Faunistyczna K., 2011 - Rzadkie ptaki obserwowane w Polsce w roku 2010. Ornis Polonica, 52: 117-149.

Faunistyczna K., 2014 - Rewizja współczesnych i historycznych stwierdzeń rzadkich ptaków w Polsce. Ornis Polonica, 55: 115-134.

Fefelov I.V., 2001 - Залет черноголовой трясогузки Motacilla feldegg на Байкал. [Vagrant Black-headed Yellow Wagtail Motacilla feldegg al Baikal]. Рус. орнитол. ж. Экспресс-вып, 167.

Feldner J., 1979 - Die Zugvögel des Lavanttales. Carinthia II, 169 (89): 409-426.

Ferlini F., 2015 - Evoluzione dell'areale riproduttivo della Cutrettola "italiana" Motacilla flava cinereocapilla. Rivista Italiana di Ornitologia, 85 (2): 3-20.

Fesenko H.V. \& Bokotej A.A., 2007 - The annotated list of the ukrainian scientific names of the bird species belonging to the Fauna of Ukraine (with characteristics of status of the species). Kyiv.

Filatova E., 2012 - Changes in avifauna of Tuzkan Lake in period of 100 years. Proceedings of the International Conference "Terrestrial vertebrates arid ecosystems", Tashkent: 290-298.

Filipenko S.I. \& Tishchenkov A.A., 2013 - Гидробиологические и орнитологические исследования биологически ценны х участков связанны х с водой экосистем в: рамсарском сайте «Нижкний Днестр».

Finsch O., 1879 - Reise nach West-Sibirien im Jahre 1876. Verhandlungen der kaiserlich-königlichen zoologisch-botanischen Gesellschaft in Wien, 29: 115-292.

Fischer Sigwart H., 1892 - Biologische Gruppirung der Ornis der Schweiz. Mitglieder-Verzeichniss des Ornithologischen Vereines in Wien, 18: 176-178.

Flint V.E., Mosalov A.A., Lebedev E.A., Boukreev S.A., Galushin V.M., Zubakin V.A., Mishchenko A.L., Sviridov T.V., Tomkovich P.S., Kharitonov N.P. \& Shitikov D.A., 2000 - ПТИЦЫ Европейской России Полевой определитель. [Birds European Russia field guide]. Moscow.

Floericke C., 1897 - Ornithologische Ergebnisse einer Reise durch Transkaukasien, Transkaspien und die Bucharei. Ornithologisches Jahrbuch, 8: 201-244. 
Forrester R.W., Andrews I.J., McInerny C.J., Murray R.D., McGowan R.Y., Zonfrillo B., Betts M.W., Jardine D.C. \& Grundy D.S., 2007 The Birds of Scotland. Scottish Ornithologists 'Club, Aberlady.

Foschi F., 1976 - Le Cutrettole italiane (Motacilla L., 1758). Uccelli d'Italia, 1: 9-15.

Frank F., 1950 - Die Vögel von Opuk (Schwarzmeer-Gebiet). Bonner zoologische Beiträge, 1: 144-2014.

Führer L., 1901 - Beiträge zur Ornis Montenegro's und des angrenzenden Gebietes von Nordalbanien. Ornithologische Jarhbuch, 12: 41-79.

Fundukchiev S.E., 1987 - On the nesting pattern of the wagtail Motacilla flava feldegg in betpak dala Kazakh SSR USSR. Vestnik Zoologii: 58 .

Fünfstück H.-J., 1999 - Avifaunistische Kurzmitteilungen aus Bayern. Avifaunistischer Informationsdienst Bayern, 6: 55-59.

Gabor K., 1981 - A tájátalakítás és a madárvilág változása. Aquila, 88: 61-63.

Ganso M., 1962 - Beobachtungen aus Jugoslawien und Nordgriechenland. Egretta, 5 (2): 60-64.

Ganso M., 1968 - Eine Maskenstelze (Motacilla flava feldegg) im Waldviertel. Egretta 11: 4.

Gâştescu P., 2006 - Lacurile Terrei. C.D.Press, Bucureşti.

Gaston K.J., 2003 - The structure and dynamics of geographic ranges. Oxford University Press, Oxford.

Gauger K. \& Heiss M., 2011 - Birding sites of the OSME Region 7. The Talish mountains region in Azerbaijan. Sandgrouse, 33 (1): 46-57.

Gauthier-Clerc M., Sadoul N., Willm L., Kayser Y., Pin C. \& Arnaud A., 2008 - Etude de définition des enjeux avifaunistiques liés à l'élaboration du DOCOB NATURA 2000 de la ZPS FR 9310019 «Camargue». Centre de recherche pour la conservation des zones humides méditerranéennes, Arles.

Gavrilov E.I., 1970 - Family Motacillidae and genera Turdus and Oenanthe. In: The birds of Kazakhstan. Vol. 3. Academiya Nauk KAZSSR, Alma-Ata.

Gavrilov E.I. \& Gavrilov A.E., 2005 - The birds of Kazakhstan. Tethys Ornithological Research, 2: 3-222.

Gavris' G.G., 2003 - Pliska chornogolova Motacilla feldegg. Ptakha Ukrainy pid receptionists Bernskoï konventsï, Delhi: 218-220.

Genè G., 1835 - Osservazioni a "Iconografia della Fauna italica" di Carlo Luciano Bonaparte. Biblioteca Italiana, 80: 22-36.

Gerakis P., 1992 - Conservation and management of Greek wetlands: Proceedings of a Greek wetlands workshop, Thessaloniki, Greece, 17-21 April 1989. IUCN, Gland, Switzerland.

Géroudet P., 1985 - Bergeronnette printanière à tête noire, Motacilla flava feldegg: deux observations en Haute-Savoie et commentaires. Nos Oiseaux, 38: 84-85.

Giglioli Hillyer E., 1890 - Primo resoconto dei risultati dell'inchiesta ornitologica in Italia. Parte seconda. Avifaune locali. Successori Le Monnier, Firenze.

Giglioli Hillyer E., 1907 - Secondo resoconto dei risultati dell'inchiesta ornitologica in Italia. Avifauna Italica. Stab. Tipografico S. Giuseppe, Firenze.

Gill F. \& Donsker D. (eds.), 2015 - IOC World Bird List (v 5.3). Doi 10.14344/IOC.ML.5.3. <http://www.worldbirdnames.org/> (retrieved on December 2015)

Giovacchini P. \& Stefanini P., 2015a - Dieci anni di censimenti dell'avifauna nidificante in Diaccia-Botrona. L'occhione. Newsletter del Gruppo Ornitologico Maremmano, Numero 53. <http://www. birdsongs.it/newsletter/news.html $>$ (retrieved on December 2015)

Giovacchini P. \& Stefanini P., 2015b - Dieci anni di censimenti (20062015) dell'avifauna nidificante ed estivante nella ZPS 'Padule di Diaccia Botrona'. In: XVIII Convegno Italiano di Ornitologia. Programma e abstract. De Sanctis A. \& Rubolini D. (eds.). Stazione Ornitologica Abruzzese Onlus.

Goldewijk K.K., 2001 - Estimanting global land use change over the past 300 years: The HYDE Database. Global Biogeochemical Cycles, 15 (2): 417-433.

Gonzenbach G, 1859 - Excursionen an die Brüteplätze von Sterna, Larus und GIareola im Golf von Smyrna. Journal für Ornithologie, 7: 309-316.

Grant C.H.B. \& Mackworth-Praed C.W., 1952 - On the species and races of the Yellow Wagtails from Western Europe to Western North America. The Bulletin of the British Museum (Natural History) Zoology, 1 (9): 253-268.
Green J. (ed.), 2014 - Scarce and rare birds in Wales 2013. The Welsh Ornithological Society. <http://www.birdsinwales.org.uk/downloads/ Rare\%20birds\%20in\%202013.pdf > (retrieved on December 2015)

Green I. \& Kolbintsev V., 2001 - The Altai Mountains where four worlds meet. 14th-29th June 2001. <http://www.cloudbirders.com/ tripreport/repository/GREENTOURS_Kazakhstan_06_2001.pdf> (retrieved on December 2015)

Green I. \& Soylu S., 2014 - Azerbaijan. A tour for the Alpine Garden Society by Greentours 30th April - 13th May 2014. <http:// www.greentours.co.uk/doc/Trip\%20Report\%20AGS\%20Azerbaijan\%202014\%20edited.pdf $>$ (retrieved on December 2015)

Grinnell J., 1914 - Barriers to distribution as regards birds and mammals. The American Naturalist, 48: 248-245.

Grishchenko V., 2004 - Checklist of the birds of Ukraine. Berkut, 13 (2): 141-154.

Grishchenko V.M. \& Yablonovska-Grishchenko E.D., 2014 - Avifaunistic observations in the south of Ukraine in 2013. Avifauna of Ukraine, 5: 9-15.

Grote H., 1928 - Die ornithologische Fauna der aralo-kaspischen Steppen. Verhandlungen der Ornithologischen Gesellschaft in Bayern, 18: 18-43.

Gstader W., 2006 - Brutnachweise aus Tirol von 2006. Vogelkundliche Berichte der Tiroler Vogelwarte, 19: 1-20.

Guerrero I., Morales M.B., Oñate J.J., Geiger F., Berendse F., de Snoo G., Eggers S., Pärt T., Bengtsson J., Clement L.W., Weisser W.W., Olszewski A., Ceryngier P., Hawro V., Liira J., Aavik T., Fischer C., Flohre A., Thies C. \& Tscharntke T., 2012 - Response of ground-nesting farmland birds to agricultural intensification across Europe: Landscape and field level management factors. Biological Conservation, 152: 74-80.

Gurney J.H., 1876 - Rambles of a naturalist in Egypt \& other countries. With an analysis of the claims of certain foreign birds to be considered british, and other ornithological notes. Jarrold, London.

Hable E., 1978 - Ornithologische Beobachtungen 1977, vorwiegend im Gebiet der Forschungsstätte "P. Blasius Hanf" am Furtnerteich (Aves). Mitteilungen der Abteilung für Zoologie am Landesmuseum Joanneum Graz, 7: 77-88.

Hable E., 1983 - Ornithologische Beobachtungen 1981, vorwiegend im Gebiet der Forschungsstätte "P. Blasius HANF" am Furtnerteich (Aves). Mitteilungen der Abteilung für Zoologie am Landesmuseum Joanneum Graz, 29: 3-17.

Hable E., Präsent I. \& Präsent S., 1999 - Das Hörfeld - ein neues Ramsargebiet in Steiermark und Kärnten mit seiner interessanten Vogelwelt. Vogelkundliche Nachrichten aus Ostösterreich, 10: 73-81.

Hafemann D., 1967 - Beobachtungen zum Frühjahrs. Vogelzug auf Kreta. Bonn zoological Bulletin, früher Bonner Zoologische Beiträge, 18: 221-233.

Hafner R., Spreitzer G., Spreitzer J., Leitner H \& Bauer J., 2007 - Georgien 12.5. - 20.5.2007 Expect the unexpected. Trip report. <http://www.club300. at/files/GeorgienTripReport200705.pdf $>$ (retrieved on December 2015)

Handrinos G. \& Akriotis T., 1997 - The Birds of Greece. Helm Field Guides, London.

Hansson S. \& Bergström M., 2013 - Armenien 3-11 Juni 2013. Trip report. <http://www.heliangelus.se/files/pdf/armenien\%202013\%20 ny.pdf $>$ (retrieved on December 2015)

Harin K.V., 2014 - The monitoring of the biodiversity of land vertebrate animals in the territory of the Shpakovsky region of the Stavropol territory. Environmental Monitoring and Biodiversity, 2 (9): 117-124.

Harms H., 1909 - Motacilla flava raddei subsp. Nov. Ornithologische Monatsberichte, 17 (1): 2.

Harrison J.M., 1933 - A contribution to the Ornithology of Bulgaria. With supplementary notes by Pawel Pateff. Ibis, 75: 494-521.

Hartert E., 1910 - Die Vögel der paläarktischen Fauna systematische Übersicht der in Europa, Nord-Asien und der Mittelmeerregion vorkommenden Vögel. Vol. 1. Berlin.

Hartert E., 1922 - Die Vögel der paläarktischen Fauna systematische Übersicht der in Europa, Nord-Asien und der Mittelmeerregion vorkommenden Vögel, Vol. 1. R. Friedländer \& Sohn, Berlin.

Harters E., Jourdain F.C.R, Ticehurst N.F. \& Witherby H.R., 1912 - A hand-list of British birds. Witherby \& Co., London.

Havrylenko V.S., Lystopadsky M.A., Mezinov O.S. \& Chegorka P.P., 2014 - A role of depression ecosystems in formation of the wetland ornithocomplexes in the interfluve of Dnieper and Molochnaya. News Biosphere Reserve "Askania Nova”, 16: 30-45. 
Heinicke T., Eichhorn G., Kamp J., Koshkin A., Lachmann L. \& Schielzeth H., 2006 - Checklist of the Birds of the Tengiz-Korgalzhyn region, Central Kasazhstan. Non pubblicata. $<$ http://www.uni-bielefeld.de/biologie/Evolutionsbiologie/images/TengizBirdList_2006. pdf $>$ (retrieved on December 2015)

Heiss M., 2010 - The breeding bird communities of the Talish mountains (Azerbaijan) and their response to forest degradation. Diploma thesis in the study programme Landscape Ecology and Nature Conservation. Ernst-Moritz-Arndt-University Greifswald.

Hellebrekers W.P.J., Ros J.H. \& Böhr H.-J., 1969 - Neue ornithologische Sommerbeobachtungen auf Korfu. Bonn zoological Bulletin - früher Bonner Zoologische Beiträge, 20: 437-440.

Hellicar M.A., Anastasi V., Beton D. \& Snape R., 2014 - Important bird areas of Cyprus. BirdLife Cyprus, Nicosia.

Hellquist A., 2011 - Yellow Wagtail distribution in Xinjiang. BirdForum. <http://www.birdforum.net/showthread.php?t=259514> (retrieved on December 2015)

Hellström M., 2009 - Gulärlor av rasen feldegg. Raritetskommitténs återgranskning av det svenska fyndmaterialet. Vår Fågelvärld, 4: 32-37.

Hengeveld' R. \& van den Bosch F., 1990 - The expansion velocity of the Collared Dove Streptopelia decaocto population in Europe. Ardea, 79 (1): 67-72.

Hennlein J., 2015 - The influence of water shortage on birds at the Ili Delta in Kazakhstan. Thesi, Leuphana Universität Lüneburg. $<$ http://opus.uni-lueneburg.de/opus/volltexte/2015/14333/pdf/Final Masterarbeit_Julia_Hennlein.pdf $>$ (retrieved on December 2015)

Heuglin T., $1869^{-}$- Ornithologie Nordost-Afrika's, der Nilquellen und Küsten-Gebiete des Rothen Meeres und des nördlichen SomalLandes. Vol. I. Theodor Fischer, Cassel.

Hirtz H., 1914 - Beiträge zur Kenntnis der Ornithofauna croatica. [Contributions to the knowledge of ornithofauna croatica]. Ornithologisches Jahrbuch, 25: 1-16.

Hoeser N., 2000 - Maskenstelze, Motacilla flava feldegg, bruetet in der Fogarascher Senke in Siebenbuergen. Mauritiana, 173: 505-506.

Hofland R., 1994 - Trip Report: Syria \& Jordan, May 8 - June 14, 1994. $<$ http://www.camacdonald.com/birding/tripreports/SyriaJordan94. html $>$ (retrieved on December 2015)

Holmstedt S., 2012 - Kazakhstan and Kyrgyzstan June 2-21 2012. <http://www.club300.se/Files/TravelReports/ka-ki\%20 reseber\%C $3 \% \mathrm{~A} 4$ ttelse \%20rev3.pdf $>$ (retrieved on December 2015)

Hölzel N., Hauba C., Ingelfinger M.P, Otte A. \& Pilipenko V.N., 2002 The return of the steppe large-scale restoration of degraded land in southern Russia during the post-Soviet era. Journal for Nature Conservation, 10 (2): 75-85.

Homes R.C., 1966 - Eine Maskenstelze (Motacilla flava feldegg) am Neusiedler See. Egretta, 9 (1): 40.

Homeyer E.F., 1878 - Beitrüge zur Gattung Budytes. Journal für Ornithologie, 26: 126-131.

Homeyer E.F., 1881 - Ornitliologische Briefe. Blätter der Erinnerung seine Freunde gesammelt von E. F. von Homeyer. Theobald Grieben, Berlin.

Homeyer E.F. \& Tancre C.A., 1883 - Beiträge zur Kenntniss der Ornithologie Westsibiriens, namentlich der Altai-Gegend. Mittheilungen des Ornithologischen Vereines in Wien.

Hoogstraal H., Kaiser M.N., Traylor A.M., Gaber S. \& Guindy E., 1961 Ticks (Ixodidae) on Birds Migrating from Europe and Asia to Africa. Bulletin de l'Organisation mondiale de la Santé, 24: 197-212.

Hoyer H., 1910 - Klucz do oznaczania zwierząt kręgowych ziem Polskich. Nakładem Kótka Przyrodników U.U.J., Cracow.

Hudson N. \& the Rarities Committee, 2010 - Report on rare birds in Great Britain in 2009. British Birds, 103: 562-638.

Institute for Nature Conservation of Serbia, 2006 - Review of significant bird species in Peštersko Polje. $<$ https://rsis.ramsar.org/RISapp/files/1652/documents/RS1656taxo.pdf $>$ ?language $=$ es $>$ (retrieved on December 2015)

Issa N., 2008 - Nidification réussie d'une Bergeronnette des Balkans Motacilla f. feldegg dans le Var. Ornithos, 15 (1): 45-49.

István C., Ottó H., Gyula H. \& István N., 1899 - Magyarország madarai különös tekintettel gazdasági jelentöségökre. Hungary Ornithologiai Központ.

István S., 1995 - A délkelet-magyarországi bíbic (Vanellus vanellus) populáció harmincéves vizsgálata. Aquila, 102: 41-52.
Ivanov A.I., 1940 - Птицы Таджикистана. М.-Л.: Изд-во АН СССР. Ivanov A.I., 1969 - Птицы Памиро. Алая: 1-447.

Jarsjö J., Asokan S.M., Shibuo Y. \& Destouni G., 2008 - Water scarcity in the Aral Sea drainage basin: contributions of agricultural irrigation and a changing climate. In: Environmental problems of Central Asia and their economic, social and security impacts. Qi J. \& Evered K.T. (eds.). Springer Netherlands: 99-108.

Jaubert J.B. \& Barthélemy-Lapommeraye, 1859 - Richesses ornithologiques du Midi de la France, description méthodique de tous les oiseaux observés en Provence et dans les départements circonvoisins. Barlatier-Feissat et Demonchy, Marseille.

Jeffries I. (ed.), 1996 - Problems of economics and political transformation in the Balkans. Pinter, London and New York.

Jennings M.C., 2010 - Fauna of Arabia, Vol. 25. Atlas of the breeding birds of Arabia. King Abdulaziz city for science \& technology, Saudi Wildlife Commission. Senckenberg Forschunginstitut und Naturmuseum. Riyadh, Kingdom of Saudi Arabia. Frankfurt am Main, Germany.

Joger U., Dujsebayeva T., Belyalov O.V., Chikin Y., Guicking D., Grachev Y.A., Kadyrbekov R. \& Miaud C., 2012 - Fauna of the Aralkum. In: Aralkum. A man-made desert: the desiccated floor of the Aral Sea (Central Asia). Breckle S.-W., Wucherer W., Dimeyeva L.A. \& Ogar N. (eds.). Springer: 199-270.

John O.B., 1889 - On the Birds of Southern Afghanistan and Kelát. Ibis, $6^{\text {a }}$ serie, 2: 145-180.

Jourdain F.C.R., 1906 - The eggs of European birds. R.H. Porter, London.

Jurkiewicz M.V., 1904 - Двадцатипятилетние итоги княжества Болгарии. 1879-1904. Опыт собрания материалов. Землеведение. Sofia.

Jusys P.V., 2012 - Ornitofaunistiniai stebéjimai Lietuvoje 2012 m. pavasarị. Paukščiai, 14: 18-25.

Kajzer Z., Guentzel S., Jasiński M. \& Sołowiej M., 2005 - Rzadkie ptaki obserwowane w latach 1999-2003 na Pomorzu Zachodnim. Notatki Ornitologiczne, 46: 95-110.

Kaleniczenko J., 1839 - Prodromus Ornithologie Tauricae. Aves. Bulletin de la Societe Imperiale des Naturalistes de Moscou, 1: 213297.

Kambourova N., 2012 - Ornithofauna of the Biosphere Reserve Srebarna Lake. In: Ecosystems of the Biosphere Reserve Srebarna Lake. Uzunov Y., Georgiev B.B., Varadinoiva E., Ivanova N., Pehlivanov L. \& Vasilev V. (eds.). Professor Marin Drinov Academic Publishing House, Sofia: 129-154.

Kamp J., 2012 - Post-Soviet land-use change and conservation of avian biodiversity across the Eurasian steppe belt. Fakultät der Westfälischen Wilhelms-Universität Münster.

Kamp J., Urazaliev R., Donald P.F. \& Hölzel N., 2011 - Post-Soviet agricultural change predicts future declines after recent recovery in Eurasian steppe bird populations. Biological Conservation, 144: 2607-2614

Karaman S.L., 1949 - Ornitofauna Skopsko Koltine. [Die Ornithofauna des Beckens voir. Skiplje in Macedonien]. Larus, 3: 196.

Karaska D., 1988 - Hniezdenie trasochvosta žltého (Motacilla flava) pri Oravskej priehrade. Zprávy MOS, 46: 131-132.

Karaska D., 2005 - 5. správa Slovenskej faunistickej komisie pre ornitológiu. Tichodroma, 17: 117-122.

Karpov F.F., 2009 - Ornithological excursion in the Ural delta in August 2008. Kazakhstan Ornithological Bulletin, 2008: 28-30.

Kattinger E., 1934 - Beiträge zur Vogelkunde Nordgriechenlands. Verhandlungen der Ornithologischen Gesellschaft in Bayern, 20 (2): 349-437.

Kattinger E., 1935 - Beiträge zur Vogelkunde Nordgriechenlands. (Fortsetzung und Schluß.). Verhandlungen der Ornithologischen Gesellschaft in Bayern, 20 (4): 484-537.

Kattinger E., 1942 - Beiträge zur "Ornis Balcanica". I Teil. Verhandlungen der Ornithologischen Gesellschaft in Bayern, 22 (2): 254-279.

Kehoe C., 2005 - The Tien Shan mountains \& deserts of Kazakhstan. Naturetrek tour report. $<$ https://www.naturetrek.co.uk/reports_new/ KAZ03_report_050501_The_Tien_Shan_Mountains_Deserts_of Kazakhstan.pd $\bar{f}>$ (retrieved on December 2015 )

Kehoe C., 2010 - Syria. Birds \& archaeology. Naturetrek. <https:// www.naturetrek.co.uk/reports_new/SYR01_report_100401 Syria_Birds_Archaeology.pdf $>$ (retrieved on December 2015) 
Kehoe C. \& BBRC, 2006 - Racial identification and assessment in Britain: a report from the RIACT subcommittee. British Birds, 99: 619-645.

Keller F.C., 1890 - Ornis Carinthiae. Die Vögel Kärntens. Monografien Vertebrata Aves, Klagenfurt.

Kennerley P. \& Kovshar V., 2005 - Kazakhstan: celestial mountains, desert \& steppe May 7th - 20th 2005 Tour report. Limosa Holidays. $<$ http://www.cloudbirders.com/tripreport/repository/LIMOSAHOLIDAYS_Kazakhstan_05_2005.pdf $>$ (retrieved on December 2015)

Kerestúr D. \& Mojžiš M., 2008 - Vtáctvo močiara pri Béteri (Lučenec, stredné Slovensko) v rokoch 1991-2008. Tichodroma, 20: 155160.

Kerven C., Alimaev I.I., Behnke R., Davidson G., Malmakov N., Smailov A. \& Wright I., 2006 - Fragmenting pastoral mobility: changing grazing patterns in post-Soviet Kazakhstan. In: Rangelands of Central Asia: transformations, issues, and future challenges. Bedunah D.J., McArthur E.D. \& Fernandez-Gimenez M. (eds.). US Department of Agriculture, Forest Service, Salt Lake City: 99-110.

Keve A., 1958 - Further population studies of the Yellow Wagtail. Bulletin of the British Ornithologists' Club, 78: 48-51.

Keve A., 1961 - Die ornithogeographische Bedeutung der "BernsteinStraße". Ornithologischer Anzeiger, 6 (2): 176-180.

Keve A., 1976 - Adatok a kisbalaton madárvilágához (II). Aquila, 83: 91-224.

Keve A., 1978 - Die Arealausbreitung der Maskenstelze Motacilla (flava) feldegg. Ornithologischer Anzeiger, 17 (3): 225-237.

Kezer K. \& Matsuyama H., 2006 - Decrease of river runoff in the Lake Balkhash basin in Central Asia. Hydrological Processes, 20: $1407-$ 1423.

Khomyakov M.M., 1900 - Птицы Рязанской губернии. Материалы к познанию фауны и флоры Росс. Империи.

Khomyakov M.M., 1900 - Uccelli della provincia di Ryazan. Materiali alla conoscenza della fauna e della flora della Russia. Impero.

Kilburn M., 1998 - Xinjiang autonomous region, China birding. 7-27 June 1998. <http://www.worldtwitch.com/xinjiang_kilburn.htm> (retrieved on December 2015)

Kiliç T. \& Eken G., 2004 - Türkiye'nin Önemli Kuş Alanları Güncellemesi. Doğa Derneği, Ankara.

Kinzelbach R. \& Martens J., 1965 - Zur Kenntnis der Vögel von Karpathos (Südliche Agäis). Bonn zoological Bulletin - früher Bonner Zoologische Beiträge, 16: 50-91.

Kirwan G., Demirci B., Welch H., Boyla K., Özen M., Castell P. \& Marlow T., 2008 - The Birds of Turkey. Cristopheer Helm, London.

Kist J. \& Waldeck K., 1961 - First record of Anthus cervinus and Motacilla flava feldegg in the Netherlands. Limosa, 34 (1): 1-6.

Klatte J.H., v. d. Oord A.M., Swaab J. \& Tekke M.J., 1962 - Short announcements: Motacilla flava feldegg in the Netherlands. Limosa, 35 (1): 167.

Kleiner A., 1936 - Mitteilungen über die Schafstelzen (Motäcilla Aves) Bulgariens und seiner angrenzenden Gebiete. Bulletin des' Institutions Royales d'Histoire Naturelle, Sophia, 9: 69-80.

Koblik E.A., Red'kin Y.A. \& Arkhipov V.Y., 2006 - Checklist of the birds of russian federation. KMK Scientific Press Ltd., Moscow.

Komarov Y.E., Ivashchenko N.A. \& Maliyev S.V., 2011 - К авифауне Моздокского района Северной Осетии-Алании. Cтрепет, 9: 38-67.

König C. \& Schwammberger K., 1963 - Schwarzköpfige Schafstelze an den Kiesgruben bei Pleidelsheim, Kreis Ludwigsburg. Ornithologischer Anzeiger, 6 (6): 570.

Kon-Tiki Tours, 2012 - Georgia 1st to 9th of July 2012: <http://www. caligata.com/tripreports/en/georgia-1-9-7-2012> (retrieved on December 2015)

Kostin Y.V., 1983 - Birds of Crimea. Nauka, Moscow.

Kostiushyn V.A., Chernichko I.I. \& Busel V.A., 2014 - Avifauna of Bilenko-Razumovskie Plavni (Kakhovskoe Water Reservoir, Zaporozhskaya Oblast) in spring-summer season. Journal of Zaporizhzhya National University. Life Sciences, 2014: 60-81.

Kovshar A.F., 2012 - Ревизия орнитофауны и современный список птиц Казахстана. [Ornithofauna revision and modern list of birds of Kazakhstan]. Ornithological News of Kazakhstan and Middle Asia, 1: 51-70.
Kreuzberg-Mukhina E.A., 2006 - The Aral Sea basin: changes in migratory and breeding waterbird populations due to major humaninduced changes to the region's hydrology. Waterbirds around the world. The Stationery Office, Edinburgh: 283-284.

Kravtsova V.I., 2001 - Analysis of changes in the Aral Sea coastal zone in 1975-1999. Water Resources, 28 (6): 596-603.

Kristensen A.B., Frich A.S., Ortvad T.E. \& Schwalbe M., 2010 Sjældne fugle i Danmark og Grønland i 2009. Rapport nr. 40 fra Sjældenhedsudvalget. <http://www.martinsoegaardnielsen.dk/blaavandshuk/litteratur/surapporter/surapport2009.pdf $>$ (retrieved on December 2015)

Krivizkiy I.A., Khrokov V.V., Volkov E.N. \& Zhuliy V.A., 1985 - Birds of Korgalzhyn nature reserve. Almaty.

Kroneisl-Rucner R., 1960 - Vom Vorkommen der Art Motacilla flava L. in Jugoslawien mit besonderen Hinblick auf die Unterart Motacilla flava cinereocapilla Savi. Larus, 12-13: 41-49.

Krüper T. \& Hartlaub G., 1875 - Zeiten des Gehens und Kommens und des Brütens der Vogel in Griechenland und Ionien. In: Griechische Jahreszeiten, Vol. 3. Mommsen A. (ed.). Schleswig.

Kumerloeve H., 1961 - Zur Kenntnis der Avifauna Kleinasiens. Mit besonderer Berücksichtigung der südlichen Landesteile (Taurus Kilikien - Nordwest-Mesopotamien). Bonn Zoological Bulletin früher Bonner Zoologische Beiträge, 12: 1-318.

Kumerloeve H., 1962 - Notes on the birds of the Lebanese Republic. Iraq Natural History Museum Pubishing, 20-21: 1-81.

Kummerlöwe H. \& Niethammer G., 1934 - Bcitrtlge zur Kenntnis der Avifauna Kleinasiens (Paphlagonien-Galatien). Journal für Ornithologie, 82 (4): 505-552.

Kus-Veenvliet J., 2001 - Rumena pastirica Motacilla flava na Cerkniškem polju (Yellow Wagtail Motacilla flava at Cerknica polje). Acrocephalus, 22 (104-105): 23-28.

Kvartalnov P., 2011 - Tugay forests in Tajikistan: the last remainders of globally endangered ecosystem. Detailed final report for 2011 Rufford Small Grants Project, No 9304-1, Moscow. <http://www. rufford.org/files/9304-1\%20Detailed\%20Final\%20Report.pdf> (retrieved on December 2015)

Kvartalnov P., 2014 - О некоторых малоизученных тицах югозапада Таджикистана. Русский орнитологический журнал, 23, Экспресс - выпуск, 1069: 3580-3586.

Kvetko R. \& FK SOS/BirdLife Slovensko, 2014 - The 14th report of the Rarities Committee of the Slovak Ornithological Society/BirdLife Slovakia. Tichodroma, 26: 97-106.

Laber J. \& Ranner A., 1997 - Nachweise seltener und bemerkenswerter Vogelarten in Österreich 1991-1995. 2. Bericht der Avifaunistischen Kommission von BirdLife Österreich. Egretta, 40 (1): 1-44.

Lachmann L., 2010 - Blue-cheeked Bee-eater, Caspian Plover, Citrine Wagtail, Collared Pratincola, Common House Martin, Common Moorhen, Desert Wheatear, Eastern Olivaceous Warbler, Eurasian Curlew, Eurasian Golden Oriole, Eurasian Spoonbill, Glossy Ibis, Great Reed Warbler, Northern Wheatear, Pallid Harrier, Red-backed Shrike, Ruddy Turnstone, Siberian Stonechat, Steppe Gull, Water Rail, Willow Warbler, Yellow-headed Wagtail. AviCA database. <www.worldbirds.org>

Lamarche B. (ed.), 1988 - Liste commentée des oiseaux de Mauritanie. Études Sahariennes et Ouest-Africaines, 1 (4): 1-162.

Landerer X., 1857 - Notizen zur Naturgeschichte von Griechenland. Der Pharmacie, 7: 369-375.

Lanfossi P., 1840 - Commentari dell'Ateneo di Brescia. Tipografia della Minerva, Brescia.

Lastukhin A.A., 2014 - Some results of the spring bird watching in Uzbekistan in 2014. <http://www.cloudbirders.com/tripreport/repository/LASTUKHIN Uzbekistan 05 2014.pdf> (retrieved on December 2015)

Lazowski W., 1997 - Auen in Österreich. Vegetation, Landschaft und Naturschutz. Monographien Band 81. Umweltbundesamt, Wien.

Le Nevé A., Gouraud C., Morlon F. \& Judas J., 2010 - Kazakhstan nature trip report; March to June 2009. National Avian Research Center. Unpublished. <http://www.centralasianbirding.com/ uploads/1/4/5/2/14521906/kazakhstan_trip_report_2009_le_neve et al.pdf $>$ (retrieved on December 2015)

Lebed E.A., 1996 - Vagrant ог the Black-headed Yellow Wagtail in north-east of Ukraine. Berkut, 5 (2): 151. 
Lehikoinen L., Aalto T., Huhtinen H., Lampila P., Lehikoinen P., Normaja J., Soilevaara K. \& Velmala W., 2013 - Rare birds in Finland in 2012. Linnut-Vuosikirja, 2012: 114-129.

Leisler B., 1968 - Probleme der Maskenstelzen (Motacilla flava feldegg). Ausbreitung nach Mitteleuropa. Egretta, 11 (1-2): 6-13.

Lelieveld J., Hadjinicolaou P., Kostopoulou E., Chenoweth J., El Maayar M., Giannakopoulos C., Hannides C., Lange M.A., Tanarhte M., Tyrlis E. \& Xoplaki E., 2012 - Climate change and impacts in the Eastern Mediterranean and the Middle East. Climatic Change, 114: 667-687.

Lilford T.L.P., 1889 - A List of the Birds of Cyprus. The Ibis, VI serie, 2: $305-350$.

Lindenthaler A., 1980 - Liste der Vögel Salzburgs (Stand April 1980). Vogelkundliche Berichte und Informationen - Land Salzburg, 82: 1-12.

Lindermayer A., 1860 - Die Vögel Griechenlands; en Beitrag zur Fauna dieses Landes. Keppler, Passau.

Lintia D., 1909 - Meine ornithologische Studienexkursion in die Dobrudscha. Aquila, 16: 156-178.

Lintia D., 1917 - Adatok Szerbia madárfaunájához (Materialien zur Avifauna Serbiens). Aquila, 23: 74-162.

Liuzzi C., Mastropasqua F. \& Todisco S., 2013 - Avifauna pugliese... 130 anni dopo. Ed. Favia, Bari.

Lorenz L., 1887 - Notizen. Annalen des Naturhistorischen Museums in Wien, 2 (3): 81-116.

Lorenz L., 1892 - Die Ornis von Oesterreich-Ungarn und den Occupationsländern im k.k. naturhistorischen Hofmuseum zu Wien. Annalen des Naturhistorischen Museums in Wien, 7: 306-372.

Lorenz T., 1887 - Beitrag zur Kenntniss der ornithologischen Fauna an der Nordseite des Kaukasus. - M. - 62 S.

Lorenzo J.A., 2008 - Lavandera boyera balcánica: nueva rareza en Canarias. [Black-headed Yellow Wagtail: new vagrant to Canary Islands]. Canary Islands Birding News. <http://avescanarias.blogspot.it/2008/05/lavandera-boyera-balcnica-nueva-rareza.html> (retrieved on December 2015)

Lorgé P. \& LHK, 2004 - Seltene Vogelarten in Luxemburg 1998-2003. 5. Bericht der Luxemburger Homologationskommission. Regulus Wissenschaftliche Berichte, 20: 49-58.

Lorgé P. \& LHK, 2014 - Seltene Vogelarten in Luxemburg 2011-2013. Bericht der Luxemburger Homologationskommission. Regulus Wissenschaftliche Berichte, 29: 46-58.

LPO Isère, 2015 - Communes de l'Isère avec Bergeronnette à tête noire (Motacilla flava feldegg). $<\mathrm{http} / / /$ oiseauxisere.free.fr/php/commune espece.php?codlat=MOTFLAFEL\&espece=Bergeronnette_\%E0_t $\%$ EAte noire (Motacilla flava feldegg) $>$ (retrieved on December 2015)

Lukač G., 2007 - Fauna Croatica. Aves XXXVII. Popis ptica Hrvatske. Natura Croatica, 16: 1-148.

Luke H.C. \& Keith-Roach E., 1922 - The handbook of Palestine. Macmillan, London.

LUKOIL Uzbekistan Operating Company LLC, 2013 - Enhanced biodiversity monitoring plan (EBMP) Khauzak-Shady Project. $<$ http:// www.miga.org/documents/Lukoil_Enhanced_Biodiversity_Monitoring.pdf $>$ (retrieved on December 2015)

Macfarlane A.M., 1978 - Field notes on the birds of Lebanon and Syria, 1974-1977. Army Bird-Watching Society, 3.

MacKinnon J. \& Phillipps K., 2000 - A field guide to the birds of China. Oxford University Press, New York.

Madarász G., 1899 - Further contribution to the Hungarian Ornis. Természetrajzi Füzetek, 22: 344-360.

Madarász G., 1899-1903 - Magyarország Madarai; a hazai madárvilág megismerésének vezérfonala. Budapest.

Magioris S.N., 1987 - Check-list of the bird species have been observed in Cyclades, Aegean-Greece, during 19th and 20th century. Ecologia Mediterranea: 13 (1/2): 15-22.

Makatsch W., 1950 - Die Vögelwelt Macedonlens. Leipzig.

Makatsch W., 1950-51 - Elne Beitrag zur Biologie der Brachschwalbe (Glareola p. pratincola (L.)). Larus, 4-5: 89.

Makatsch W., 1952-55 - A Délkelet-Eurőpai madarak elterjedésének határa és eltolódásai. Aquila, 59-62: 339-342.

Malherbe A., 1843 - Faune ornithologique de la Sicile: avec des observations sur l'habitat ou l'apparition des oiseaux de cette ile, soit dans le reste de l'Europe, soit dans le nord de l'Afrique; précédée d'un aperçu de l'histoire politique, scientifique, littéraire et artistique de la Sicile. Extrait des Mémoires de l'Académie royale de Metz, année 1842, 1843.
Marques D.A., Thoma M., Knaus P. \& Vallotton L., 2013 - Oiseaux rares et observations inhabituelles en Suisse en 2012. 22e Rapport de la Commission de l'Avifaune Suisse. Nos Oiseaux, 60: 215-236.

Martorelli G., 1960 - Gli uccelli d'Italia, terza edizione. Rizzoli, Milano.

Maštrović A., 1942 - Die Vögel des Küstenlandes Kroatiens. Vol. 1. Institut für Angewandte Zoologie in Zagreb.

Matruhan T.I., 2010 - Seasonal aspects of the ecological structure of meadow birds northern Azov. In: Current approaches and methods for the study of rational use and protection of biodiversity. Proceedings of the First All-Russian Youth School-Seminar, Tomsk: 148-150.

Matruhan T.I., 2013 - The significance of the small rivers of the Northern Azov to maintain a high diversity of bird. In: Current approaches and methods for the study of rational use and protection of biodiversity. Proceedings of the All-Russian Youth School-Seminar with international participation, Tomsk: 101-108.

Matvejev S.D. \& Vasić V.F., 1973 - Catalogus Faunae Jugoslaviae, IV/3, Aves. Consilium Academiarum Scientiarum Reipublicae Socialisticae Foederativae Jugoslaviae. Academia Scientiarum et Artium Slovenica, Ljubljana.

Matvejev S.D. \& Vasić V.F., 1977 - Prve dopune i korekcije za Catalogus faunae Jugoslaviae. Aves (Addenda et corigenda ad Catalogum faunae Jugoslaviae. Aves). Larus, 29-30 (1976-77): 123-136.

Mayaud N., 1936 - Inventaire des Oiseaux de France. Blot Editeur, Paris.

Mayaud N., 1940 - Commentairs sur l'Ornithologie Francaise. Alauda, Suppl.: 59-136.

Mayaud N., 1952 - Motacilla flava L. en France, ses races, leur distribution géographique et leurs migrations. Alauda, 20 (1): 1-20.

Mayr E. \& Greenway J.C. Jr., 1960 - Check-list of birds of the World. Vol. IX. Museum of Comparative Zoology, Cambridge, Massachusetts.

Mayrose A. \& Alon D., 2002 - The red book of vertebrates in Israel. Society for the Protection of Nature in Israel and Israel Nature and Parks Authority.

McCarthy E.M., 2006 - Handbook of avian hybrids of the world. $O x$ ford University Press, New York.

McCauley M., 1976 - Khrushchev and the development of soviet agriculture: The Virgin Lands program 1953-1964. Holmes \& Meier, New York.

Meiklejohn M.F.M., 1948 - Summer notes on Birds of Tehran and Elburz Mountain. Ibis, 90 (1): 76-86.

Meir Z., 1956-57 - Breeding data from Israel. Aquila, 63-64: 366.

Melnikov Y.I., 2015 - Modern climate changes and dynamics of areas of coastal birds in Eastern Siberia. In: Modern problems of zoology, ecology and conservancy. Andreyeva T.F., Vershinina T.A., Bannikova A.A., Makarova E.A. \& Frolov V.E. (eds.). SAO "Moscow State Zoological Park", Moscow: 219-224.

Melnikov Y.I. \& Gagina-Scalon T.N., 2014 - Changes in bird fauna of Lake Baikal throughout the XX and the beginning of XXI centuries. Amurian Zoological Journal, 6 (4): 418-446.

Menetries E., 1832 - Catalogue raisonné des objets de zoologie: recueillis dans un voyage au Caucase et jusqu'aux frontières actuelles de la Perse. Académie impériale des sciences, St. Petersburgh.

Mezzavilla F., 1989 - Atlante degli uccelli nidificanti nelle province di Treviso e Belluno (Veneto) 1983-1988. Museo Civico di Storia e Scienze Naturali di Montebelluna.

Michahelles K., 1830 - Ueber einige dalmatinische Vertebraten, die zugleich im westlichen Asien vorkommen. Isis von Oken, 23: 809-820.

Michalczuk J., 2014 - Expansion of the Syrian Woodpecker Dendrocopos syriacus in Europe and Western Asia. Ornis Polonica, 55: 149-161.

Miho A., Kashta L. \& Beqiraj S., 2013 - Between the Land and the Sea. Ecoguide to discover the transitional waters of Albania. University of Tirana.

Milne \& McAdams, 2008 - Irish Rare Bird Report 2007. Irish Rare Birds Committee, Kilcoole.

Ming M., 2011 - A checklist on the distribution of the birds in Xinjiang. Huayu Nature Book.

Molchanov L.A., 1906 - Список птиц Естественно. Исторического Музея Таврического Губернского Земства. К Познанию Фауны и Флоры Российской Империи, 7: 1-60. 
Molnár I., 1969-70 - Motacilla flava feldeggi in the County of Baranya. Aquila, 76-77: 194.

Molnár, I. 1976 - Kucsmás billegető (Motacilla flava feldeggi) megfigyelése. Aquila, 83: 293.

Moltoni E., 1975 - L'Avifauna dell'Isola di Capraia (Arcipelago toscano). Rivista Italiana di Ornitologia, 45: 97-217.

Moltoni E. \& Brichetti P., 1976 - Elenco degli Uccelli Italiani. Rivista Italiana di Ornitologia, 48: 65-142.

Molodovsky A.V., 1997 - Field guide Stein. Birds. University of Nizhny Novgorod, Nizhny Novgorod.

Moore H.J. \& Boswell C., 1957 - Field observations on the birds of Iraq. Part III. Iraq Natural History Museum, Baghdad.

Morris G., 2011 - Birds in Greater Bulgaria, May 2nd-12th, 2011. $<$ http://www.glennmorris.org.uk/Bulgaria\%202011/BulgariaBirds2011.htm $>$ (retrieved on December 2015)

Moschini E., 1981 - Cronaca ornitologica livornese. Osservazioni interessanti dal Marzo 1975 al Dicembre 1979. II. FalconiformiPasseriformi. Quaderni del Museo di Storia Naturale di Livorno, 2: 95-97.

MoskalenkoY.,2015-Фаунатанаселенняптахівнижньодніпровських піщаних масивів. Національної академії наук україни, Kiev.

Moskát C., 1975 - Kucsmás sárgabillegető (Motacilla flava feldeggi) fészkelése az Ipoly árterében. Aquila, 82: 237.

MOTC, 2012 - KAZ: CAREC Corridor 2 (Mangystau Oblast Section) Investment Program. Tranche 2. Environmental impact assessment. Ministry of Transport and Communications for the Asian Development Bank.

Müller A., 1879 - Zur Ornithologie der Insel Cypern. Journal für Ornithologie, 27: 385-393.

Munteanu D., 2006 - On the systematic position and evolution of the Black-headed Yellow Wagtail. Romanian Journal of Biology-Zoology, 51 (1-2): 3-11

Munteanu A. \& Dârmiceanu V., 2010 - Lake Aral. Planetary scale ecological disaster. In: Resursele de apă din România. Vulnerabilitate la activităţile antropice. Gâştescu P. \& Brețcan P. [Water resources from Romania. Vulnerability to the pressure of man's activities]. Conference Proceedings, 11-13 June 2010. Editura Transversal, Targoviste: 456-461.

Muraviev I.V., 2010 - Экология группы “желтоватых” трясогузок в Среднем Поволжье // Бутурлинский сборник: матер. III Всерос. Бутурлинских чтений. Ульяновск: Изд-во "Компания технологий продвижения": 241-252.

Muraviev I.V., 2013 - Биоэкологические основы и механизмы симпатрии у птиц на примере видов группы «желтых» трясогузок (Passeriformes: Motacillidae, Motacillinae). Ulyanovsk.

Muraviev I.V. \& Artemyeva E.A., 2012 - Yellow-headed Wagtail (Motacilla lutea) in the Volga-Kama and Volga Areas. Berkut, 21 (1-2): $102-115$.

Muraviev I.V. \& Artemyeva E.A., 2014a - Breeding biology of blackheaded wagtail Motacilla feldegg (passeriformes, motacillidae, motacillinae) in Rostov oblast of Russia. Vestnik zoologii, 48 (1): 67-74.

Muraviev I.V. \& Artemyeva E.A., 2014b - Some additions and comments to breeding biology of Blackheaded Wagtail Motacilla feldegg Michahhelles, 1830 (Passeriformes, Motacillidae, Motacillinae) in European Russia. Advances in Bioscience and Bioengineering, 2 (1): 1-15.

Murdoch D., 2003 - My second Syrian trip (10-19 June 2003): REPORT. <http://www.guidedbirding.pwp.blueyonder.co.uk/Information/syriatriprep.htm $>$ (retrieved on December 2015)

Murdoch D., 2007 - Bird sites of the OSME region: 3. Mheimideh. Jewel on the Euphrates. Sandgrouse, 29: 98-102.

Murdoch D. \& Betton K.F., 2008 - A checklist of the birds of Syria. Sandgrouse, supplement, 2: 1-48.

Myrbach H., 1968 - Maskenstelzen (Motacilla flava feldegg) in Österreich. Beobachtungen von Maskenstelzen bei Innsbruck. Egretta, 11: 2-3.

Natorp O., 1925 - Motacilla flava feldeggi Mich, in Oberschlesien erbeutet. Ornithologische Monatsberichte, 33: 122-124.

Naumann J.F., 1897 - Naturgeschichte der Vögel Mitteleuropas. Vol. 3. Gera-Untermhaus, Köhler.
Neergaard R.S., 2013 - Sjældne fugle i Danmark og Grønland i 2012. Rapport nr. 43 fra Sjældenhedsudvalget. $<$ http://www.martinsoegaardnielsen.dk/blaavandshuk/litteratur/surapporter/surapport2012. pdf $>$ (retrieved on December 2015)

Nesterenko M., Dyakov O., Drumea D. \& Doroftei M., 2014 - Change adaptation strategy and action plan for Danube delta region Romania, Ukraine, Moldova. WWF Danube Carpathian Programme Romania, Danube Biosphere Reserve Ukraine, Center for Regional Studies Ukraine, NGO Ecospectr Moldova.

Nicoll M.J., 1919 - Handlist of the birds of Egypt. Government Press, Cairo.

Niethammer G., 1940 - Motacilla flava feldegg Mich, in der Ostmark. Ornithologische Monatsberichte, 48: 163.

Niethammer G., 1942 - Nachtrag zu den ornithologischen Beobachtungen in Ost-Oberschlesien. Annalen des Naturhistorischen Museums in Wien, 53 (1): 337-339.

Niethammer G., 1966 - Briefe C. L. Brehms an C.F. Bruch, 1827-1857. Bonner Zoologische Beitraege, 17: 87-134.

Nisbet I.C.T., 1967 - Frühjahrs. Vogelzug auf Paros (Kykladen). Bonn zoological Bulletin, früher Bonner Zoologische Beiträge, 18: 234252.

Oates E.W., 1890 - The fauna of British India, including Ceylon and Burma. Vol. 2. Taylor and Francis, London.

Ödeen A., 2001 - Effects of Post-Glacial Range Expansions and Population Bottlenecks on Species Richness. Acta Universitatis Upsaliensis, Comprehensive Summaries of Uppsala Dissertations from the Faculty of Science and Technology, Uppsala, 664.

Olphe-Galliard L., 1890 - Contributions à la faune ornithologique de l'Europe occidentale. Lyon, Berlin.

Olschewski S., 2011 - Die Brutvogelgemeinschaften der Halbwüsten, Lichtgehölze und Waldsteppen des Kopetdaggebirges (Süd-Turkmenistan). Dissertation, Ernst-Moritz-Arndt-Universität Greifswald.

Olsen T.A., Bunes V., Egeland Ø., Gullberg A., Mjølsnes K.R. \& Tveit B.O., 2010 - Sjeldne fugler i Norge i 2008. Rapport fra Norsk Sjeldenhetskomité for Fugl (NSKF). Ornis Norvegica, 33: 4-48.

Orbie G., 2013 - Birding in Armenia 9-19 May 2013. Trip report. <http://www.mergus.be/wp-content/uploads/2013/06/ARMENIE2013 GO.pdf $>$ (retrieved on December 2015)

Ornitofaunistika, 2015 - Dzeltenā cielava Motacilla flava flava. $<$ http://ornitofaunistika.com/lvp/motfla.htm> (retrieved on December 2015)

Otarov A. \& Ibrayeva M., 2002 - Co-ordination of scientific activities towards elaboration of common strategy for environmental protection and sustainable management in Syr Darya River Basin, in Uzbekistan and Kazakhstan. Report Proposal No 26199. Syr Darya.

Ots M. \& Lilleleht V., 2002 - Linnuharuldused Eestis 1998-2000. Hirundo, 15: 59-82.

Ottó H., 1899 - Magyarország Madarai. Vol. 2. Magyar Ornithologiai Központ. Budapest.

Otus, 2012 - Checkliste der Vögel Bayerns. Alle seit dem 01.01.1980 in Bayern nachgewiesenen Vogelarten. Erläuterungen siehe unten. Stand: Januar 2012. <http://www.otus-bayern.de/formulare/ Checkliste_1980_Stand_01012012.pdf $>$ (retrieved on December 2015)

Ovaa A., van der Laan J., Berlijn M. \& CDNA, 2008 - Rare birds in the Netherlands in 2007. Dutch Birding, 30: 369-389.

Paludan K., 1938 - Ornis des Zagrossgebietes, W.-lran. Zur Ornis des Zagross-Gebietes, 86: 562-638.

Paludan K., 1959 - On the Birds of Afghanistan. Dansk naturhistorisk forening. Videnskabelige meddelelser. Reitzel, Copenhagen.

Parodi R. (ed.), 1999 - Gli uccelli delle provincia di Gorizia. Pubblicazione N. 42. Museo Friulano di Storia Naturale.

Patev P., 1950 - Birds of Bulgaria. Bulgarian Academy of Sciences, Sofia.

Patrizi-Montoro F., 1909 - Materiali per un'Avifauna della provincia di Roma (con note del marchese prof. Giuseppe Lepri). Bollettino della Società Zoologica Italiana, 10: 1-103.

Pavlova A., Zink R.M., Drovetski S.V., Red'kin Y. \& Rohwer S., 2003 - Phylogeographic patterns in Motacilla flava and Motacilla citreola: species limits and population history. The Auk, 120 (3): 744-758. 
Pedersen T., 2008 - Birds of the United Arab Emirates. An annotated checklist. [Unpublished report]. <http://bio.wits.ac.za/Craig/Raptors/Amur $\% 20 \& \% 20$ falcon $\% 20$ references/Pederson $\% 202008 \% 20$ -\%20Birds\%20of\%20the\%20United\%20Arab\%20Emirates\%20 -\%20Unpubl\%20report.docx> (retrieved on December 2015)

Pedersen T. \& Aspinall S.J. (eds.), 2014 - EBRC Annotated Checklist of the birds of the United Arab Emirates. EAD, Abu Dhabi.

PekloA.M. \& Til'ba P.A., 2007-The birds of Soviet forestry (Western Ciscaucasus). The collection of works Zoological Museum, 39: 69-80.

Pelle I., 1957 - Die Maskenstelze (Motacilla flava feldegg Mich.) in Pancevacki rit. Larus, 11: 154.

Perevozov A.G., 2012 - Орнитофауна кавказского заповедника и сопредельных территорий.

Perlman Y. \& Meyrav J., 2009 - Checklist of the birds of Israel. Israel Ornithological Center, Society for the Protection of Nature in Israel.

Pettersson T., 2012 - Trip report: Turkmenistan, 3rd to 14th May 2012. $<$ http://www.cloudbirders.com/tripreport/repository/PETTERSSON Turkmenistan 05 2012.pdf> (retrieved on December 2015)

Petz E., 1984 - Maskenstelze (Motacilla flava feldegg Michahelles) im oberen Mühlviertel, OÖ. Egretta 27 (2): 86-88.

Picchi C., 1904 - Elenco degli uccelli osservati nella sua collezione ornitologica italiana al 29 febbraio 1904. Ornis, 12: 381-562.

Pigot A.L., Owens I.P.F. \& Orme C.D.L., 2010 - The environmental limits to geographic range expansion in birds. Ecology Letters, 13: 705-715.

Piot B. \& Vallotton L., 2012 - Oiseaux rares et observations inhabituelles en Suisse en 2011. 21e Rapport de la Commission de l'avifaune Suisse. Nos Oiseaux, 59: 207-228.

Poggiani L. \& Dionisi V., 2002, ultima modifica 01.04.2013 - Cutrettola Motacilla flava. In: La Valle del Metauro. Aspetti naturali e antropici del bacino del Metauro. Ed. Associazione Naturalistica Argonauta e Comune di Fano, Fano (PU), consultata il 05.11.2014. $<\mathrm{http}: / /$ www.lavalledelmetauro.it $>$ (retrieved on December 2015)

Pope M. \& Zogaris S. (eds.), 2012 - Birds of Kuwait. A comprehensive visual guide. KUFPEC, Biodiversity East, Cyprus.

Portales A., 2015 - Motacilla flava feldegg 1 ind La Graciosa, Canary Islands. In: Rare Birds in Spain. <https://www.facebook.com/permalink.php?story_fbid $=10152818854027761 \& \mathrm{id}=47728497760>$ (retrieved on December 2015)

Porter R.F. \& Aspinall S., 2010 - Birds of the Middle East. Cristopher Helm, London.

Porter R.F., Salim M., Ararat K. \& Fadhel O., 2010 - A provisional checklist of the birds of Iraq. Marsh Bulletin, 5 (1): 56-95.

Präsent S., 1977 - Ornithologische Beobachtungen im Gebiete des Hörfeldes und seiner weiteren Umgebung aus den Jahren 19741976 (Aves). Mitteilungen der Abteilung für Zoologie am Landesmuseum Joanneum Graz, 6: 73-80.

Prazák J.P., 1897 - Materialien zu einer Ornis Ost-Galiziens. 45 (3): 225-348.

Přribil S., 1983 - Sýc rousný (Aegolius funereus) a konipas luční předoasijský (Motacilla flava feldeggi) na Třeboňsku. Sylvia, 22: 78-79.

Probst R. \& Bartas J., 2013 - Schafstelze brütet wieder in Kärnten (Wagtail breeds again in Carinthia). 16. Ornithologischer Rundbrief Kärnten - Oktober 2013. BirdLife Österreich Landesgruppe Kärnten.

Qureshi A.S., Qadir M., Heydari N., Turral H. \& Javadi A., 2007 - A review of management strategies for salt-prone land and water resources in Iran. Colombo, Sri Lanka. International Water Management Institute. IWMI Working Paper, 125.

Radde G., 1884 - Ornis Caücasica. Die Vogelwelt des Kaukasus. Verlag von Theodor Fischer, Kassel.

Radde G., 1886 - Reisen an der Persisch-russischen Grenze: Talysch und seine Bewohner. F.A. Brockhaus, Leipzig.

Radde G., 1899 - Die Sammlungen des Каикаsiscнеn Museums. Typographie der Kanzelei des Landeschefs.

Radde G. \& Walter A., 1890 - Wissenschaftliche Ergebnisse der im Jahre 1886 allerhöchst befohlenen Expedition nach Transkaspien. Vol. 1. Zoologie. Gustav Fischer, Jena.

Radeva S. \& Alexandrov V., 2009 - Climate variability and change over the Balkan Peninsula and related impacts on sunflower. In: Climate variability, modeling tools and agricultural decision-making. Utset A. (ed.). Nova Science Publishers, New York.

Radu D., 1975 - Coexistenta a 2 subspecii de codobatura galbena (Motacilla flava) in Delta Dunarii. Muzeal de Ştiinţele Naturii Bacău, Studii si Comunicari: 259-268.

Radu D., 1979 - Pasarile din Delta Dunarii. Ed. Academiei, Bucuresti.

Ramadan-Jaradi G., Bara T. \& Ramadan-Jaradi M., 2008 - Revised checklist of the birds of Lebanon 1999-2007. Sandgrouse, 30 (1): 20-69.

Ramadan-Jaradi G. \& Ramadan-Jaradi M., 1997 - Notes on some breeding birds in Lebanon. Sandgrouse, 19 (2): 122-125.

Ramadan-Jaradi G. \& Ramadan-Jaradi M., 1999 - An updated checklist of the birds of Lebanon. Sandgrouse, 21 (2): 132-170.

Ramos Melo J.J. \& González Del Campo P., 2014 - Cambio climático y migración de aves en la región de Souss Massa Drâa e Islas Canarias. Instituto Tecnológico de Canarias.

Ramsay W.R.G., 1923 - Guide to the birds of Europe and North Africa. Gurney and Jackson, London.

Ranner A. \& Khil L., 2011 - Nachweise seltener und bemerkenswerter Vogelarten in Österreich 2007-2009. 6. Bericht der Avifaunistischen Kommission von BirdLife Österreich. Egretta, 52: 13-32.

Raß P., Feldner J., Wagner S. \& Zmölnig J., 1999 - Rote Liste der Brutvögel Kärntens (Vertebrata: Aves). Publikationen Naturschutz Kaernten, $R L: 105-112$.

Reeber S., Frémont J., Flitti A. \& le CHN, 2008 - Les oiseaux rares en France en 2006-2007. 25e rapport du Comité d'homologation national. Ornithos: 15 (5): 313-355.

Reeber S. \& le CHN, 2012 - Les oiseaux rares en France en 2011. 29 rapport du Comité d'Homologation National. Ornithos, 19 (6): 353-395.

Reichholf J.H., 1977 - Ornithologische Studien in Jugoslawien. Mitteilungen der Zoologischen Gesellschaft Braunau, 3: 1-28.

Reichholf-Riehm H., 1976 - Faunistische Kurzmitteilungen aus Bayern (15). Ornithologischer Anzeiger, 15 (1): 85-92.

Reinsch A., 1975 - Maskenstelze Motacilla flava feldegg bei Pleinfeld/ Mfr. Ornithologischer Anzeiger, 14 (2): 211

Reiser O., 1888 - Liste der bisher durch Belegstücke für Bosnien und die Herzegowina nachgewiesenen Vögel. Mitteilungen des Ornithologischen Vereins in Wien, 12: 35.

Reiser O., 1892 - Nove tečevine Zemaljskog muzeja od ptica u Bosne i Hercegovine. Glasnik Zemaljskog Muzeja, 4 (2): 101-104.

Reiser O., 1894 - Materialien zu einer Ornis Balcanica. Vol. II. Bulgarien (einschliesslich Ost-Rumeliens und der Dobrudscha). Hrsg. vom Bosnisch-Herzegowinischen Landesmuseum in Sarajevo, Wien.

Reiser O., 1905 - Materialien zu einer Ornis Balcanica. Vol III. Griechenland und die Griechischen Inseln. Hrsg. vom Bosnisch-Herzegowinischen Landesmuseum in Sarajevo. Wien.

Richardson C., 2012 - Systematic list for June \& July 2012. BirdLife Cyprus. <http://www.birdlifecyprus.org/upload/PDFs/Sightings\%20Archive/sightings jun\&july2012.pdf $>$ (retrieved on December 2015)

Roberts P. \& Bishop K.D., 2009 - Kazaksthan and Uzbekistan birding the best of Central Asia May 23 - June 11, 2009. <http://www. ventbird.com/system/tour_departure/legacy_birdlist/1033/809KZ_ BL.pdf $>$ (retrieved on December 2015)

Robertson I.S., 1970-71 - Black-headed Yellow Wagtail in Shetland. Scottish birds, 6: 176.

Robien P., 1928 - Die Vogelwelt Pommerns. Abhandlungen und Berichte der Pommerschen Naturforschenden Gesellschaft, 9: 1-94.

Robinson S. \& Milner-Gulland E.J., 2003 - Political change and factors limiting numbers of wild and domestic ungulates in Kazakhstan. Human Ecology, 31: 87-110.

Robl J., 2007 - Ornitholische Kartierung des Naturschutzgebietes Zellersee Süd. 2006. Salzburger Vogelkundliche Berichte, 12: 1-11.

Roháĉek F., 1919 - Übersicht über die Brutvögel der Bocche die Cattaro. Ornithologische Jahrbuch, 28, 116-129.

Rohrhofer J., 1932 - Seltene und bemerkenswerte Gäste auf der Welser Heide. Blätter für Naturkunde und Naturschutz, 19 (5): 65-67.

Romanov I.R. \& Berezovikov N.N., 2015 - Птицы карьерных водоёмов Чуйской долины. Русский орнитологический журнал, 24: 1271-1279. 
Root T., 1988 - Environmental-factors associated with avian distributional boundaries. Journal of Biogeography, 15: 489-505.

Roshydromet, 2005 - Strategic prediction for the period of up to 20102015 of climate change expected in Russia and its impact on sectors of the russian national economy. Moscow.

Roshydromet, 2008 - A Evaluation report on climate change and its consequences in the Russian Federation. Moscow.

Rössler E., 1903 - Popis Ptica hrvatske faune Koje su prispjele narodnom zoološkom muzeju u Zagrebu do konca godine 1900. Glasnik hrvatskoga Naravoslovoga Društva, 14: 11-90.

Rouse J., 2011 - Birding with a helmet on by. <http://www.osme.org/ sites/default/files/pdf/AfghanistanBirdListMay_Sept2011.pdf> (retrieved on December 2015)

Ružić M. \& Pantović U., 2007 - Ptice gnezdarice Suve Morave na Zapadnoj Moravi kod Èaèka. Ciconia, 15: 60-67.

Ružić M., Pantović U. \& Radaković M., 2006 - Red-footed Falcon Falco vespertinus. Acrocephalus, 27 (128-129): 99-113.

Ryabitsev V.K., 2001 - Birds Urals, Urals and Western Siberia: Spravochnik- determinant. Ekaterinburg.

Ryabtsev A., 2014 - Syrdarya control and Northern Aral Sea phase11 (SYNAS-11) project. Feasibility study report 3. Preliminary environmental impact assessment. Republic of Kazakhstan, Ministry of Environment and Water Resources. Committee for Water Resources.

Sabo R., Legáth J. \& Sabová L., 2010 - Focal bird species for refined exposure assessment in accordance with the Guidance document (EFSA) under Directive 91/414/EEC. National Reference Laboratory for Pesticides UVLF, Košice.

Sacchi M., d'Alessio S \& Balestrieri R., 2010 - Monitoraggio delle popolazioni degli uccelli migratori in ingresso nel Lazio meridionale (migrazione primaverile). Progetto piccole isole 20 marzo - 20 maggio 2010. Associazione Cibele Onlus. <http://www.parcocirceo.it/public/documenti/Migratori_Zannone_2010_4.pdf> (retrieved on December 2015)

Sagardia J. \& García VargasF.J., 2010-Black-headed Yellow Wagtail Motacilla flava feldegg 'superciliaris'. In: Rare Birds in Spain. <http:// www.rarebirdspain.net/arbsf064.htm>(retrievedonDecember2015)

Sakata V.V., Akatova T.V., Bibin A.R., Grabenko E.A., Eskin N.B., Zagurnaya Y.S., Zashibat M.V., Kudaktin A.N., Loktionova O.A., Perevozov A.G., Spasovski Y.N., Tilba P.A., Timuhin I.N., Tuniev B.S., Tuniev S.B. \& Chumachenko Y.U., 2008 - Природные комплексы Имеретинской низменности: биологическое разнообразие, созологическая значимость, рекомендации по сохранению. Копи-Принт, Краснодар.

Salim M., Porter R. \& Rubec C., 2009 - A summary of birds recorded in the marshes of southern Iraq, 2005-2008. BioRisk, 3: 205-219.

Salvadori T., 1872 - Fauna d'Italia. Parte seconda: Uccelli. Vallardi, Milano.

Salvadori T., 1886 - Elenco degli Uccelli Italiani. Annali del Museo Civico di Storia Naturale di Genova, ser. II, vol. III.

Samwald F., 1968 - Brutnachweis der Maskenstelze (Motacilla flava feldegg) bei Güssing. Egretta, 11: 4.

Samwald F., 1975 - Ornithologische Beobachtungen, vorwiegend in der Oststeiermark, in den Jahren 1973 und 1974 (Aves). Mitteilungen der Abteilung für Zoologie am Landesmuseum Joanneum Graz, 4: 123-138.

Santone P., 1994 - Uccelli d'Abruzzo nidificanti nelle zone umide. Regione Abruzzo, Pescara.

Sassi M., 1937 - Vögel von Rodi und von einigen ägäischen Inseln. Verhandlungen der Ornithologischen Gesellschaft in Bayern, 21 (2): 91-122.

Satunin K.A., 1907 - Guide to the birds of the Caucasus. Tiflis.

Savoskul O.S., Chevnina E.V., Perziger F.I., Vasilina L.Y., Baburin V.L., Danshin A.I., Matyakubov B. \& Murakaev R.R., 2003 - Water, climate, food, and environment in the Syr Darya Basin. Contribution to the project ADAPT.

Sayer J.A. \& van der Zon A.P.M., 1981 - National Parks and Wildlife Management. Afghanistan. A contribution to a conservation strategy. Food and Agri culture Organisation of the United Nations, Volume II: Appendixes.

Schenk J., 1917 - Fauna Regni Hungariae, Aves. Regia Societas Scientarum Naturalium Hungarica, Budapest.
Schenk J., 1918 - Übersicht der Geschichte der Ornithologie in Ungarn. [Overview of the history of ornithology in Hungary]. Aquila, 25: $31-88$

Schenk J., 1939-1942 - Zusätze und Ergänzungen zu dem Namensverzeichnis der Vögel des historischen Ungarns. Aquila, 46-49: 3-4.

Schierhorn F., Müller D., Prishchepov A.V., Faramarzi M. \& Balmann A., 2014 - The potential of Russia to increase its wheat production through cropland expansion and intensification. Global Food Security, 3 (3-4): 133-141.

Schifferli A., 1968 - Die Maskenstelze (Motacilla flava feldegg) als Brutvogel im Tessin. Ornithologische Beobachter, 65: 38-42.

Schifferli L., 2001 - Birds breeding in a changing farmland. Acta Ornithologica, 36 (1): 35-51.

Schinz H.R., 1837 - Verzeichniss der in der Schweiz vorkommenden Wirbelthiere. Neuchatel.

Schinz J., 1964 - Die Vogelwelt des Neeracher Riedes - Ergänzende Beobachtungen von 1953-1963. Vierteljahrsschrift der Naturforschenden Gesellschaft in Zürich, 109: 373-408.

Schlegel H., 1844 - Revue critique des oiseaux d'Europe. Paris.

Schneider-Jacoby M., SchwarzU., Sack1P., Dhora D., Saveljic D. \& Stumberger B., 2006a - Rapid assessment of the ecological value of the Bojana-Buna Delta (Albania/Montenegro). Euronatur, Radolfzell.

Schneider-Jacoby M., Rubinić B., Sackl P. \& Stumberger B., 2006b - A preliminary assessment of the ornithological importance of Livanjsko Polje (Cetina River Basin, Bosnia and Herzegovina). Acrocephalus, 27 (128/129): 45-57.

Schrader G., 1892 - Ornithologische Beobachtungen auf meinen Sammelreisen. Ornithologisches Jahrbuch, 3 (2): 1-54.

Schuster S., 1983 - Die Vögel des Bodenseegebietes. Ornithologische Arbeitsgemeinschaft Bodensee, Konstanz.

Sclater P.L., 1904 - On the Birds of Sibthorp's "Fauna Græca". The Ibis, 8 (4): 222-227.

Scott D., 2001 - The Birds of Lake Orumiyeh and adjacent wetlands, Islamic Republic of Iran. The Results of Surveys carried out by the Ornithology Unit of the Department of the Environment in the 1970s. <http://sites.wetlands.org/reports/ris/2IR003_Annex.pdf $>$ (retrieved on December 2015)

Sedláèek K. \& Horáèek J., 1983 - Prùzkum avifauny Státní pøírodní rezervace Novozámecký rybník. Sb. Severoèes. Muz. Ser. Sci. Natur., 3: 101-120.

Selosse N. \& la Commission d'Homologation, 2002 - Rapport de la Commission d'Homologation. Années 1996 et 1997. Aves, 38: 127-157.

Serhal A.A. \& Khatib B.C. (eds.), 2014 - State of Lebanon's birds and IBAs. SPNL, Beirut.

Sharpe R.B., 1885 - Catalogue of the Passeriformes or the Perching Bird in the collection of the British Museum. Vol. X. Taylor and Francis, London.

Sharpe R.B., 1891 - Scientific results of the second Yarkand mission. Government of India, London.

Shelley G.E., 1872 - A Handbook of the Birds of Egypt. John van Voorst, London.

Shirihai H., 1996 - The birds of Israel. Academic Press, London.

Shukurov E.J., 1991 - A systematic list of birds of Kyrgyzstan. Bishkek.

Siadat H., 1998 - Iranian agriculture and salinity. Proceedings of the conference on new technologies to combat desertification. 12-15 October, Tehran: 10-14.

Siblet J.P. \& Tostain O., 1984 - Un mâle de Bergeronnette printanière, Motacilla flava, du type feldegg, nicheur en Seine-et-Marne (France). Nos Oiseaux, 37: 284-288.

Sidenko M.V., 2003 - Орнитофауна Города Ростова-На-Дону (Avifauna of Rostov-on-Don). Thesis for the degree of Candidate of Biological Sciences, Rostov State University, Rostov.

Simon A., 1969-1971 - Ornithologische Beobachtungen in Macedonien 1968. Monticola, 2: 97-110.

Simpson F. \& Ketchen L., 2008 - South \& East Turkey. 28 June - 13 July 2008. <http://www.fssbirding.org.uk/turkey2008trip.htm> (retrieved on December 2015)

Siokhin V., Chernichko I., Kostyushyn V., Krylov N., Andrushchenko Y., Andrienko T., Didukh Y., Kolomijchuk V., Parkhisenko L., Chernichko R. \& Kirikova T., 2000 - Sivash, the lagoon between two seas. Wetlands International, Kyiv - AEME. 
Škornik I., 2012 - Favnistični in ekološki pregled ptic Sečoveljskih solin. Izdajatelj Soline Pridelava soli d. o. o.

Smiles M., Pedersen T. \& Campbell O., 2012 - Birds of the United Arab Emirates. Annual Report 2010. Emirates Bird Record Committee.

Sotta-BachmayrL.,LindnerR.,Medicus-ArnoldC.,ParkerJ.,RoblJ., Sinn B., Sinn E. \& Werner S., 1993 - Die situation wiesenbrütender vogelarten im bundesland salzburg. Vogelschütz in Österreich, 8: 26-30.

Spitzer G. \& Ganso M., 1967 - Weitere Beiträge zur Avifauna Kleinasiens. Egretta, 10 (2): 9-25.

Stani W., 1975 - Ornithologische Beobachtungen im Bezirk Leibnitz im Jahre 1974 (Aves). Mitteilungen der Abteilung für Zoologie am Landesmuseum Joanneum Graz, 4: 139-149.

Stani W., 1978 - Ornithologische Beobachtungen in der südlichen Steiermark, unter besonderer Berücksichtigung des Murstausees Gralla, im Jahre 1977 (Aves). Mitteilungen der Abteilung für Zoologie am Landesmuseum Joanneum Graz, 7: 125-134.

Stani W., 1980 - Ornithologische Beobachtungen aus des Südsteiermark, unter besonderer Berücksichtigung des Vogelschutzgebietes "Murstausee Gralla", im Jahre 1979 (Aves). Mitteilungen der Abteilung für Zoologie am Landesmuseum Joanneum Graz, 9: 107-124.

Starikov S.V., 2008 - Черноголовая трясогузка Motacilla feldegg. In: Казахстанский орнитологический бюллетень 2007. Tethys: 149-150.

Stepanian L.S., 1990 - Конспект орнитологической фауны CCCP. Наука.

Stiftung M.S., 2013 - Bewertung des Naturschutzpotentials der Nordküste des Kleinen Aralsees. <http://www.umweltbundesamt.de/ sites/default/files/2013_06_10_machbarkeitsstudie_kleiner_aralsee_barrierefrei_0.pdf> (retrieved on December 2015)

Stresemann E., $192 \overline{0}$ - Avifauna macedonica. M. Dultz \& co., München.

Stresemann E., 1943 - Überblick über die Vögel Kretas und den Vogelzug in der Ägäis. Journal für Ornithologie, 91: 448-514.

Stresemann E., 1956 - Bausteine zu einer Ornithologie von Kreta. Journal für Ornithologie, 97: 44-72.

Stuart Baker E.C, 1926 - The fauna of British India, including Ceylon and Burma. Vol. 3. Taylor and Francis, London.

Stumberger B., Schneider Jacoby M. \& Sack1 P., 2004 - Domestic breeds of the Bojana-Buna Delta (Albania-Montenegro). Workshop "Rare Breeds of the Balkan", Dimitrovgrad, Serbia, 22-24 September 2004. <http://www.agrobiodiversity.net/balkan/pdf/Montenegro/Stumberger_Bojanadelta.pdf $>$ (retrieved on December 2015)

Stumberger B., Sackl P., Saveljic D. \& Schneider-Jacoby M., 2008 Management plan for the conservation and sustainable use of the natural values of the privately owned Nature Park "Solana Ulcinj", Montenegro. Joannea Zoologie, 10: 5-84.

Südbeck P., Bauer H.G., Boschert M., Boye P. \& Knief W., 2007 - Rote Liste der Brutvögel Deutschlands. 4. Fassung - 30 Novembre 2007. Ber. Vogelschultz, 44: 23-81.

Sudfeldt S., Dröschmeister R., Frederking W., Gedeon K., Gerlach B., Grüneberg C., Karthäuser J., Langgemach T., Schuster B., Trautmann S. \& Wahl J., 2013 - Vögel in Deutschland. 2013. DDA, BfN, LAG VSW, Münster.

Survillo A.V., 1971 - Birds of the Zaysan depression and their connection with ARBO viruses. PhD dissertation. Almaty.

Sushkin P.P., 1908 - Птицы Средней Киргизской степи (Тургайская область и восточная часть Уральской). Москва.

Sushkin P.P., 1914 - Die Vögel der Mittleren Kirgisensteppe. Journal für Ornithologie, 62 (3): 297-332.

Sushkin P.P., 1938 - Birds of Soviet Altai and adjacent parts of Northwestern Mongolia. 2 vol. Moscow. Leningrad.

Svoboda S. \& Černý W., 1946 - Konipas luční černohlavý (Motacilla flava feldegg) na Moravě. Sylvia, 8 (3-4): 85-88.

Swinhoe C., 1882 - On the Birds of Southern Afghanistan. The Ibis, 4 (6): 145-180.

Szabó J., 1974 - Quantitative and qualitative characterization of the avifauna of the Maros-Side (1965-1967). Tiscia, 10: 145-155.

Szabó L.V., 1975 - Kucsmás sárgabillegető (Motacilla flava feldeggi) fészkelése a Hortobágyon. Aquila, 82: 236.

Tailly M., 2001 - Trip Report: Armenia 06-20 July 2001. <http://users. telenet.be/tailly/armenia2/armeniabird2001.htm $>$ (retrieved on December 2015)
Talpeanu M., 1967 - Expansion einiger Vogelarten in Rumänien. Beiträge zur Vogelkunde, 12: 345-353.

Talpeanu M. \& Paspaleva M., 1981 - Changements qualitatifs enregistré dans l'ornithofaune de roumanie au cours des trois dernirres decennies. Travaux de Muséum d'Histoire Naturelle "Grigore Antipa", 23: 243-257.

Taylor D., 1999 - Trip report: Kazakhstan, May 27 - June 5, 1999. $<$ http://www.camacdonald.com/birding/tripreports/Kazakhstan99. $\mathrm{html}>$ (retrieved on December 2015)

Temminck C.J., 1835 - Manuel d'ornithologie, ou tableau systématique des Oiseaux qui se trouvent en Europe; précédé d'une analyse du système général d'ornithologie, et suivi d'une table alphabétique des espèces. Troisième Partie. Seconde Édition. Edmond D'Ocagne, Paris.

Thibault M., Kayser Y., Tamisier A., Sadoul N., Chérain Y., Hafner H., Johnson A. \& Isenmann P., 1997 - Compte rendu ornithologique Camarguais pour les années 1990-1994. Revue d Ecologie (Terre Vie), 5: 261-315.

Ticehurst N.F., 1903 - Some notes of rare birds from Kent and Sussex. The Zoologist, 7: 418-422.

Ticehurst C.B, 1922 - Notes on Indian Wagtails. Journal of the Bombay Natural History Society, 28 (3-4): 1082-1090.

Ticehurst C.B., 1927 - The birds of British Baluchistan. Journal of the Bombay Natural History Society, 32: 64-97.

Ticehurst C.B., Buxton P.A. \& Cheeseman R.E., 1922 - Birds of Mesopotamia. Part I. Journal of the Bombay Natural History Society, 28: $210-250$.

Tohidifar M., Kaboli M., Karami M. \& Sadough M.B., 2009 - Observations on breeding birds of Meyghan wetland and adjacent areas, Markazi Province, West-Central Iran. Podoces, 4 (2): 124-129.

Tomiałojć L., 1990 - Ptaki Polski. Rozmieszczenie i liczebność, PWN, Warszawa.

Toropova V.I. \& Kulagin S.I., 2006 - The third systematic list of birds of Kyrgyzstan. Selevinia, Alma-Ata.

Toschi A., 1986 - Avifauna Italiana. Editoriale Olimpia, Firenze.

Tostain O. \& Siblet J.P., 1981 - La Bergeronnette Motacilla flava feldegg nicheuse en 1980 près de Montereau, Seine-et-Marne: premier cas de reproduction en France. Le Passer, 18: 149-150.

Townshend T., 2013 - Latest bird news from Beijing. <http://birdingbeijing.com/latest-bird-news-from-beijing/> (retrieved on December 2015)

Tristram H.B., 1864 - Report on the birds of Palestine. Proceedings of the Zoological Society of London: 1-32.

Tristram H.B., 1866 - On the Ornithology of Palestine. Part IV. The Ibis, 8 (3): 280-292.

Tristram H.B., 1884 - The survey of western Palestine. The fauna and flora of Palestine. The Committee of the Palestine Exploration Fund, London.

Trott A.C., 1947 - Notes on birds seen in the Lar Valley in 1943 and 1944. Ibis, 89 (2): 231-234.

Tschusi V. \& Dalla-Torre K., 1887 - III. Jahresbericht (1884) des Comite's für ornithologische Beobachtungs-Stationen OesterreichUngarn. Ornis, 3: 161-360.

Tschusi V. \& Dalla-Torre K., 1888 - Jahresbericht des Comites für ornithologische Beobachtungs-Stationen in Oesterreich und Ungarn 5. Jahresbericht des Comites für ornithologische BeobachtungsStationen in Oesterreich und Ungarn.

Tyler S.J., 2004 - Family Motacillidae (Pipits and Wagtails). In: Handbook of the Birds of the World. Vol. 9. Cotingas to Pipits and Wagtails. Del Hoyo, J., Elliott A. \& Christie D.A. (eds.). Lynx Edicions, Barcelona: 686-787.

Uhl H., 2003 - Schafstelze Motacilla flava flava. In: Atlas der Brutvögel Oberösterreichs. Brader M. \& Aubrecht G. (eds.). Biologiezentrum der Ostösterreich. Landesmuseen, Linz: 300-301.

United Arab Emirate Forum, 2013 - <http://www.uaebirding. com/forum/showthread.php?6444-A-baby-for-the-feldeggfamily\&highlight $=$ feldegg $>($ retrieved on December 2015$)$

U.S. Central Intelligence Agency, 1993 - Atlas of the Middle East. $<$ https://www.loc.gov/item/93676946/> (retrieved on December 2015)

Vallon G., 1907 - Fauna Ornitologica Friulana (Fine). Bollettino della Società Adriatica di Scienze Naturali in Trieste, 23: 93-231. 
van Beirs M., 2013 - Turkestan 15 may - 2 june 2013. Trip report. $<$ http://www.birdquest-tours.com/pdfs/report/TURKESTAN\%20 REP\%2013-ebook.pdf> (retrieved on December 2015)

van den Berg M. \& Oreel G.J., 1985 - Field identification of blackheaded Yellow Wagtails in Western Europe. British Birds, 78: 176183.

van den Elzen R., 2010 - Type specimens in the bird collections of the Zoologisches Forschungsmuseum Alexander Koenig, Bonn. Bonn Zoological Bulletin, 59: 29-77.

van den Schoor D., 2003 - Kazakhstan 29th May till 10th June 2003. Trip report. $<$ http://www.birdtours.co.uk/tripreports/kazakhstan/ kaz4/kaz-03.htm> (retrieved on December 2015)

van der Dol J. \& Valkenburg M., 2009 - Birding the desert and mountains of SE Kazakhstan. May 24th - June 6th 2009. <http:// www.sandwichbirdtours.co.uk/trip_reports/kaz_2009.pdf $>$ (retrieved on December 2015)

van Duivendijk, 2010 - Advanced Bird ID Guide: The Western Palearctic. New Holland Publishers, London.

Vasić V. \& Obratil V., 1990 - Zbirka ptica iz srbije u Zemaljskom Muzeju Bosne i Hercegovine u Sarajevu. Glasnik Zemaljskog Muzeja, 29: 1-184.

Vasiliu G.D., 1966 - Ornithologische Beobachtungen auf Maliuc und seiner Umgebung (Donaudelta) in den Jahren 1960-1962. Egretta, 9 (1): 1-7.

Vaurie C., 1957 - Systematic notes on Palearctic birds. No. 25, Motacillidae: the Genus Motacilla. American Museum Novitates, 1832: $1-16$.

Vavř́k M., 2002 - Zpráva České faunistické komise za období 19992001. České faunistické komise. <http://fkcso.cz/ZpravaFK19992001.pdf $>$ (retrieved on December 2015)

Vavř́k M. \& FK ČSO, 2011 - Zpráva Faunistické komise ČSO za rok 2010. [Rare birds in the Czech Republic in 2010]. Sylvia, 47: 159174

Vavř́k M. \& FK ČSO, 2012 - Zpráva Faunistické komise ČSO za rok 2011. [Rare birds in the Czech Republic in 2011]. Sylvia, 48: 181196.

Vavř́k M. \& FK ČSO, 2013 - Zpráva Faunistické komise ČSO za rok 2012. [Rare birds in the Czech Republic in 2012]. Sylvia, 49: 165189.

Verroken L. \& Verroken D., 1995 - Breeding record of a Black-headed Yellow Wagtail (Motacilla flava feldegg) in Western Hainaut (Belgium). Aves, 32 (4): 219-226.

Vlacos C., Trigou R. \& Stavrakas L., 2013 - Birding in Greece. Hellenic Ornithological Society, Athens.

Vogrin M., 1998 - Kompleks rumena pastirica Motacilla flava v Sloveniji (Complex of the Yellow Wagtail Motacilla flava (sub)species in Slovenia). Falco, Koper, 12: 67-70.

Vogrin M. \& Mikliè M., 2004 - Structure of the breeding bird assemblages in the fields with wheat (Northeastern Slovenia). Berkut, 13 (2): $189-192$.

Vongrej D. \& Darolova A., 1994 - Nidification of Motacilla flava feldegg (Michahelles, 1830) in Slovakia. Biologia, 49 (5): $795-$ 796.

Wagner S., 1977 - Brut der Maskenstelze in Kärnten. Egretta, 20 (1): 46.

Warga K., 1952-55 - Cetti’s Warbler and Black-headed Yellow Wagtail at Kisbalaton. Aquila, 59-62: 448.

Wassink A., 2009 - Birds of Kazakhstan: new and interesting data, part 2. Dutch Birding, 31: 101-110.

Wassmer S. \& Haag C., 2011 - Seltene Vogelarten und ungewöhnliche Vogelbeobachtungen in der Schweiz im Jahre 2010. 20. Bericht der Schweizerischen Avifaunistischen Kommission. Der Ornithologische Beobachter, 108 (4): 275-303.

Weiß I., 2012 - Seltene Vogelarten in Baden-Württemberg 2010. Ornithologische Jahreshefte für Baden-Württemberg, 28: 57-66.

Wellstein O., 1938 - Die Vogelwelt der Aegäis. Journal für Ornithologie, 86: 9-53.

Westermann Schulbuch, 2010 - Diercke International Atlas. Westermann Schulbuch, Braunschweig.

Wetlands International, 2003 - Directory of Azov-Black Sea Coastal Wetlands: Revised and updated. Black Sea Program of Wetlands International, Kyiv, Ukraine.
Whitaker J.I.S., 1905 - The birds of Tunisia. Being a history of the birds found in the regency of Tunis. Vol. 1. R.H. Porter, London.

Winding N., 1974 - Erster Sicht- und Brutnachweis der Maskenstelze (Motacilla flava feldegg) im Lande Salzburg. Vogelkundliche Berichte und Informationen - Land Salzburg, 59: 1-2.

Winding N., 1975 - Erster Brutnachweis der Maskenstelze (Motacilla flava feldegg). Egretta, 18 (2): 67.

Winding N., 1979 - Zur Vogelwelt des Zeller Sees, insbesondere des Naturschutzgebietes Zeller See-Südufer, Zeil am See, Salzburg. Vogelkundl Ber. Inf. Ausgabe Salzburg, 78: 1-25.

Witherby H.F., 1903 - An ornithological journey in Fars, South-west Persia. The Ibis, 8 (3), 501-570.

Witherby H.F., 1920 - A practical handbook of British birds. Vol. 1. Witherby \& Co., London.

Witherby H.F. \& Woosnam R.B., 1907 - On a collection of birds from Western Persia and Armenia. The Ibis, 49: 74-111.

Woschitz M., 1968 - Maskenstelzen (Motacilla flava feldegg) in Österreich. Motacilla flava feldegg am Völkermarkter Stausee (Kärnten). Egretta, 11: 3-4.

Wruss W., 1977 - Vogelkundliche Beobachtungen aus Kärnten. Carinthia II, 167 (87): 387-392.

Wruss W., 1978 - Vogelkundliche Beobachtungen aus Kärnten 1977. Carinthia II, 168 (88): 425-429.

Wruss W., 1979 - Vogelkundliche Beobachtungen aus Kärnten (Beobachtungszeitraum: 1. Jänner bis 31. Dezember 1978). Carinthia II, 169 (89): 251-257.

Wruss W., 1986 - Vogelkundliche Beobachtungen aus Kärnten 1985. Carinthia II, 176 (96): 565-574.

Wüst W., 1976 - Verlauf und Ergebnisse zweier Frühjahrsfahrten in den Jahren 1974 und 1975 durch Zentralasien: Usbekistan, Tadschikistan und (nur 1974) Kasachstan. Anzeiger der Ornithologischen Gesellschaft in Bayern, 15: 121-160.

Wüst W., 1986 - Avifauna Bavariae. Die Vogelwelt Bayerns im Wandel der Zeit. Vol. 2. Pterocliformes Flughühner bis Passeriformes Sperlingsvögel. Ornithologische Gesellschaft in Bayern.

Yevtushenko G.A. \& Litvinenko S.P., 2010 - Станично-луганський рибгосп - Територія, важлива для збереження видового різноманіття птахів луганської області. Птииь Бассейна Северского Дониа, 11: 201-224.

Zahavi A., 1957 - The breeding birds of the Huleh Swamp and Lake (northern Israel). Ibis, 99: 600-607.

Zarudny N.A., 1888 - Ornithological fauna of Orenburgsky territory. Notes of the Academy of Sciences, 57, Suppl. 1.

Zarudny N.A., 1889 - Rechekches Zoologisque dans la contrée TransCaspienne. Societe Imperiale des Naturalistes de Moscou, 3: 740 846.

Zarudny N.A., 1897 - Additions to the "Ornithological fauna of the Orenburg region". Materials to the knowledge of the fauna and flora of the Russian Empire. Dep. Zool., 3: 171-312.

Zarudny N.A., 1911 - Verzeichnis der Vögel Persiens. Journal für Ornithologie, 59: 185-241.

Zavialov P.O., 2005 - Physical oceanography of the dying Aral Sea. Praxis Publishing, Chichester.

Zhang X., Aguilar E., Sensoy S., Melkonyan H., Tagiyeva U., Ahmed N., Kutaladze N., Rahimzadeh F., Taghipour A., Hantosh T.H., Albert P., Semawi M., Karam Ali M., Al-Shabibi M.H.S., Al-Oulan Z., Zatari T., Al Dean Khelet I., Hamoud S., Sagir R., Demircan M., Eken M. \& Adiguzel M., 2005 - Trends in Middle East climate extreme indices from 1950 to 2003. Journal of Geophysical Research, 110: 1-12.

Zoï Environment Network, 2009 - Climate change in Central Asia. Zoï Environment Network, Geneve.

Zonn I.S., Glantz M.H., Kostianoy A.G. \& Kosarev A.N., 2009 - The Aral Sea encyclopedia. Springer-Verlag, Berlin Heidelberg.

Zuna-Kratky T., 1990 - Beobachtungen Frühlingszug 1990. Vogelkundliche Nachrichten aus Ostösterreich, 1 (3): 7-14. 